\title{
Airflow Resistance of Loose-Fill Mineral Fiber Insulations in Retrofit Applications
}

C.J. Schumacher and M.J. Fox Building Science Laboratories

J. Lstiburek

Building Science Corporation

February 2015 


\section{NOTICE}

This report was prepared as an account of work sponsored by an agency of the United States government. Neither the United States government nor any agency thereof, nor any of their employees, subcontractors, or affiliated partners makes any warranty, express or implied, or assumes any legal liability or responsibility for the accuracy, completeness, or usefulness of any information, apparatus, product, or process disclosed, or represents that its use would not infringe privately owned rights. Reference herein to any specific commercial product, process, or service by trade name, trademark, manufacturer, or otherwise does not necessarily constitute or imply its endorsement, recommendation, or favoring by the United States government or any agency thereof. The views and opinions of authors expressed herein do not necessarily state or reflect those of the United States government or any agency thereof.

Available electronically at http://www.osti.gov/bridge

Available for a processing fee to U.S. Department of Energy and its contractors, in paper, from:

U.S. Department of Energy

Office of Scientific and Technical Information

P.O. Box 62

Oak Ridge, TN 37831-0062

phone: 865.576 .8401

fax: 865.576.5728

email: mailto:reports@adonis.osti.gov

Available for sale to the public, in paper, from:

U.S. Department of Commerce

National Technical Information Service

5285 Port Royal Road

Springfield, VA 22161

phone: 800.553 .6847

fax: 703.605.6900

email: orders@ntis.fedworld.gov

online ordering: http://www.ntis.gov/ordering.htm 


\title{
Airflow Resistance of Loose-Fill Mineral Fiber Insulations in Retrofit Applications
}

\author{
Prepared for: \\ The National Renewable Energy Laboratory \\ On behalf of the U.S. Department of Energy's Building America Program \\ Office of Energy Efficiency and Renewable Energy \\ 15013 Denver West Parkway \\ Golden, CO 80401 \\ NREL Contract No. DE-AC36-08GO28308
}

\author{
Prepared by: \\ C.J. Schumacher and M.J. Fox \\ Building Science Laboratories \\ 167 Lexington Ct., Unit5 \\ Waterloo, ON, Canada \\ and \\ J. Lstiburek \\ Building Science Corporation \\ 3 Lan Drive, Suite 102 \\ Westford, MA 01886 \\ NREL Technical Monitor: Stacey Rothgeb \\ Prepared under Subcontract No. KNDJ-0-40337-05
}

February 2015 
The work presented in this report does not represent performance of any product relative to regulated minimum efficiency requirements.

The laboratory and/or field sites used for this work are not certified rating test facilities. The conditions and methods under which products were characterized for this work differ from standard rating conditions, as described.

Because the methods and conditions differ, the reported results are not comparable to rated product performance and should only be used to estimate performance under the measured conditions. 


\section{Contents}

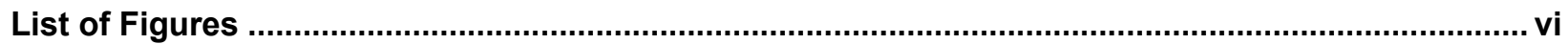

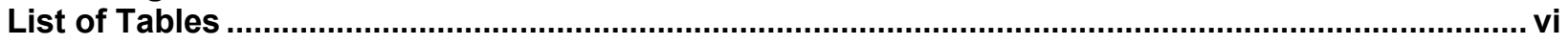

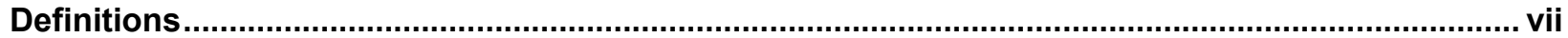

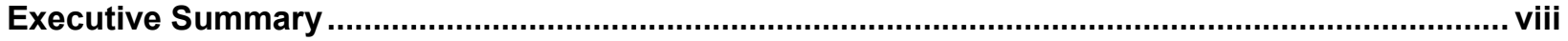

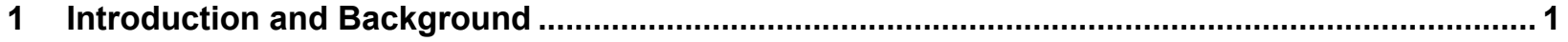

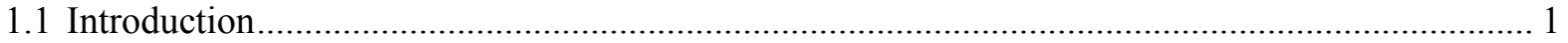

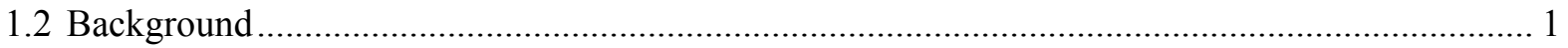

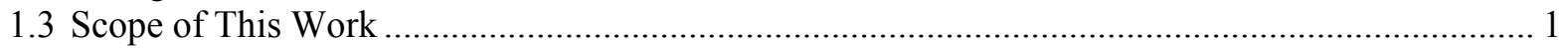

1.4 Material Sample Identification and Collection ...................................................................... 1

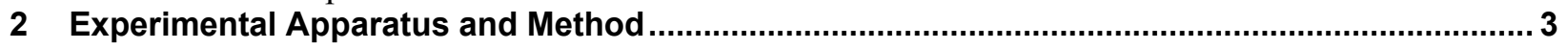

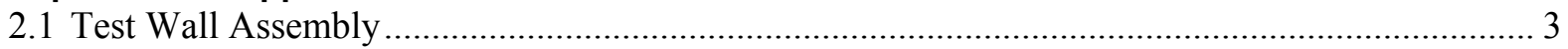

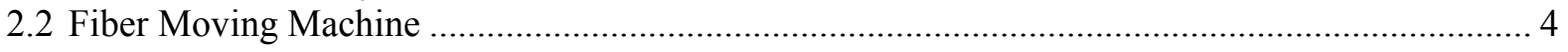

2.3 Manufacturer-Recommended Installation Methods and Densities ............................................. 5

2.4 Installation Methods and Densities for Test Wall Specimens ................................................... 9

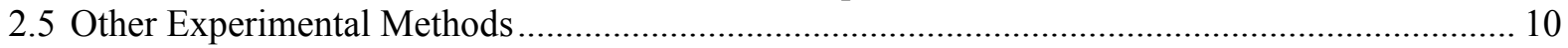

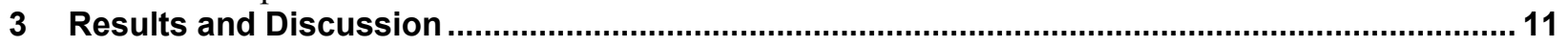

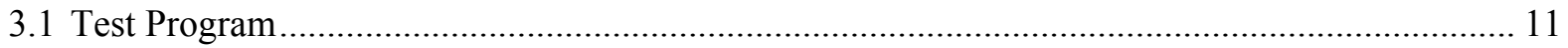

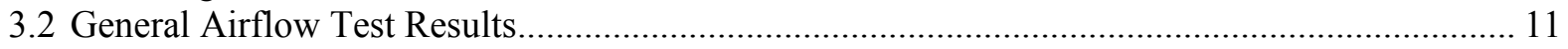

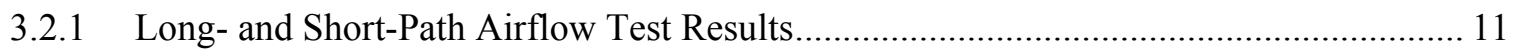

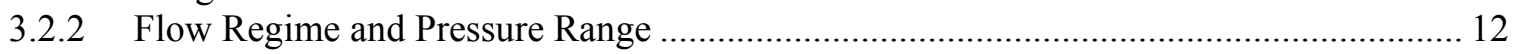

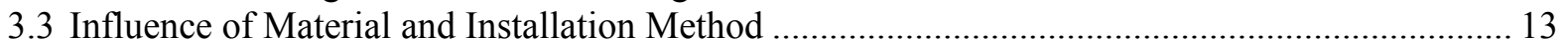

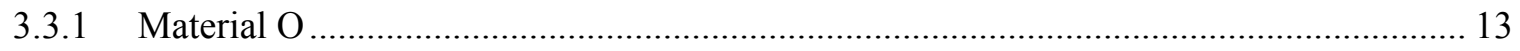

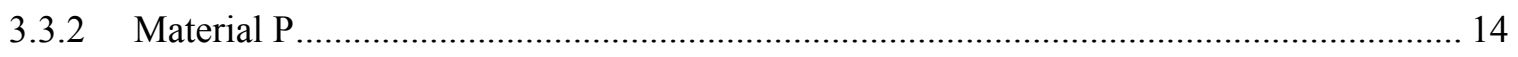

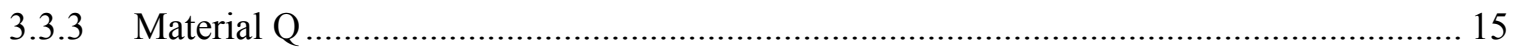

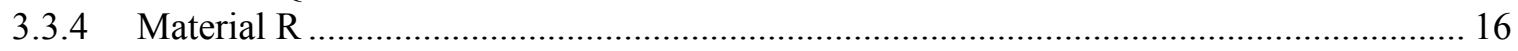

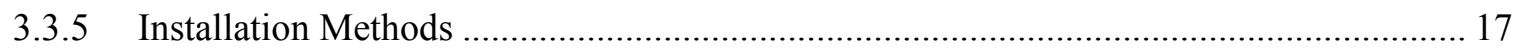

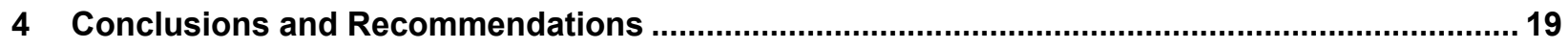

Appendix A: Loose-Fill Fiberglass Insulation Products for Dense-Pack Retrofit Applications ....... 21

Appendix B: Loose-Fill Stone Wool Insulation Products (Not Intended for Dense-Pack Retrofit

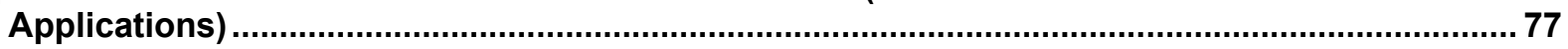

Appendix C: Example of Dense-Packing Instructions From a Cellulose Insulation Manufacturer.. 89 


\section{List of Figures}

Figure 1. Schematic of airflow paths through test wall assembly ................................................... 3

Figure 2. InsulMaxx 2000 all fiber machine (left) with double agitators (right) .................................. 4

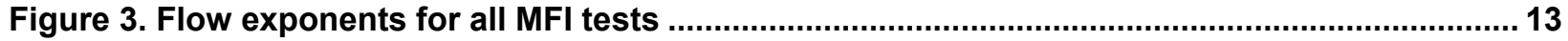

Figure 4. Flow exponents for previous CFI tests ..................................................................... 13

Figure 5. Material O: long-path airflow rest results versus installed density and

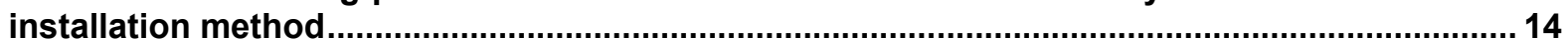

Figure 6. Material P: long-path airflow rest results versus installed density and

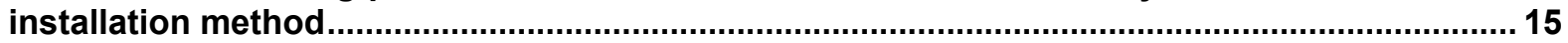

Figure 7. Material Q: long-path airflow rest results versus installed density and installation method

Figure 8. Material R: long-path airflow rest results versus installed density and installation method

Unless otherwise noted, all figures were created by Building Science Corporation.

\section{List of Tables}

Table 1. Survey of Dense-Pack and Retrofit Information for Loose-Fill Fiberglass Products........... 6

Table 2. Survey of Machine and Hose Recommendations for Dense-Pack and Retrofit

Applications Using Loose-Fill Fiberglass Products

Table 3. Survey of Recommended Dense-Pack and Retrofit Techniques for Loose-Fill

Fiberglass Products

Table 4. Summary of Mineral Fiber Test Results With Comparison to Previous Cellulose Tests.... 11

Unless otherwise noted, all tables were created by Building Science Corporation. 


\section{Definitions}

BPI

CFI

$\mathrm{cfm}$

$\mathrm{ft}^{2}$

$\mathrm{ft}^{3}$

ID

MFI

pcf

psi

scfh
Building Performance Institute

Cellulose fiber insulation

Cubic feet per minute

Square foot

Cubic foot

Inside diameter

Mineral fiber insulation

Pounds per cubic foot

Pounds per square inch

Standard cubic feet per hour 


\section{Executive Summary}

In 2011, Building Science Corporation, working under the Building America Program, completed research to support the development of standards for testing the airflow resistance of insulation materials used in dense-pack retrofit applications. Building America Report 1109, High Impact Project: Support of Standards Development - Dense-pack Airflow Resistance, Final Research Report, provides a detailed summary of the research program, including a summary of airflow resistance test results for 10 cellulose fiber insulation materials. Recently, mineral fiber insulation (MFI) materials (glass fiber, stone wool, etc.) have also been developed and/or suggested for dense-pack retrofit applications. Testing is needed to support the inclusion of MFI in new dense-pack air resistance standards.

This report expands on Building America Report 1109 by applying the experimental apparatus and test method to dense-pack retrofit applications using MFI materials. Three fiberglass insulation materials and one stone wool insulation material were tested, and the results compared to the cellulose results from the previous study. Test wall specimens were prepared to cover densities in the range of roughly 1.8-2.5 pcf. Three installation methods were tested, based on a survey of installation instructions provided by a sample of five fiberglass manufacturers: (1) bottom fill, using an insertion tube installed up through a hole at approximately $24 \mathrm{in}$. above the bottom plate; (2) top fill, using an insertion tube installed down through a hole at approximately 6 in. below the top plates; and (3) 2-in. nozzle, installed through two or three holes (e.g., at holes approximately 24 in., 72 in., and 90 in. above the bottom plate).

Airflow resistance varied significantly between loose-fill fiberglass products, even though all the compared products are marketed and supported for use in dense-pack retrofit applications. When these fiberglass products were installed at approximately $2.2 \mathrm{pcf}$, the variance was $0.33-1.73$ $\mathrm{cfm}_{50} / \mathrm{ft}^{2}$. The distribution of the installed material, and thus the airflow resistance, also depend on installation method.

Two of the three loose-fill fiberglass products tested (installed at approximately $2.3 \mathrm{pcf}$ ) produced long-path flow rates of 0.28 and $0.42 \mathrm{cfm}_{50} / \mathrm{ft}^{2}$ and short-path airflow rates of 0.76 and $1.1 \mathrm{cfm}_{50} / \mathrm{ft}^{2}$. These are comparable to the cellulose dense-pack retrofits benchmarks of 0.33 and $1.0 \mathrm{cfm}_{50} / \mathrm{ft}^{2}$ for the long- and short-path airflow rates, respectively (cellulose fiber insulation installed at $3.5 \mathrm{pcf}$ as required by Building Performance Institute). However, the fiberglass test walls were prepared using the 2-in. nozzle installation method, not the insertion tube methods recommended as best practice for retrofit applications. These results indicate a potential for dense-pack applications of MFI, but more work needs to be done to develop appropriate standards for real-world installation needs. In particular, further testing should be conducted to establish recommended install densities for insertion tube installation methods.

None of the stone wool manufacturers support dense-pack retrofit applications using their products. As a result, only one loose-fill stone wool insulation product was collected for testing. The stone wool fibers and nodules were too large to successfully install using either of the insertion tube techniques. Loose-fill stone wool is not recommended for dense-pack retrofit applications. 


\section{Introduction and Background}

\subsection{Introduction}

This report documents airflow resistance test results for dense-pack retrofit applications using mineral fiber insulation (MFI) materials (i.e., glass fiber and stone wool). The test results are compared to previous airflow resistance tests for dense-pack retrofit applications using 10 different cellulose fiber insulation (CFI) materials.

\subsection{Background}

In the early 1980s, researchers acknowledged and studied the airflow resistance of dense-pack CFI in materials in retrofit applications (EDU 1986). In 2011, Building Science Corporation (BSC), working under the Building America Program, completed research work to support the development of standards for testing the airflow resistance of insulation materials used in densepack retrofit applications. Building America Report 1109, High Impact Project: Support of Standards Development - Dense-pack Airflow Resistance, Final Research Report, provides a detailed summary of the research program, including the test apparatus and method that were developed (Schumacher 2011). The same report also provides a summary of airflow resistance test results for $10 \mathrm{CFI}$ materials.

More recently, MFI materials (glass fiber, stone wool, etc.) have been developed and/or suggested for dense-pack retrofit applications. Research is needed to develop standards for airflow resistance for these new materials. More specifically, testing is needed to support the development of two new standards by the Building Performance Institute (BPI): BPI-102, which will set requirements for the airflow resistance of insulation used in retrofit cavity (dense-pack) installations, and BPI-103, which will define acceptable test methods to measure the airflow resistance of insulation materials used in dense-pack applications.

\subsection{Scope of This Work}

This report documents airflow resistance test results for three fiberglass insulation materials and one stone wool insulation material.

\subsection{Material Sample Identification and Collection}

Suitable mineral insulation materials were identified through discussion with weatherization industry practitioners, a review of literature from trade publications and online sources, and through discussion with a manufacturer experts' panel from the North American Insulation Manufacturers Association.

To begin sample selection, five fiberglass insulation materials were identified as intended for and/or used in retrofit wall applications:

- Certainteed's Optima

- Guardian's CWI Plus

- Johns Manville's Spider

- Knauf's EcoFill-WX

- Owens Corning's ProPink L77. 
BSC collected six or more sample bags of each fiberglass retrofit product from the respective manufacturers. Appendix A includes manufacturer's literature for each of the products. Three fiberglass products were randomly selected from the five products collected.

Four stone wool insulation manufacturers produce granular/loose-fill products in North America; however, none of these are intended for or (to the best of BSC's knowledge) used in retrofit wall applications:

- Amerrock's RockWool Premium Plus

- Rolan’s Fibra Mineral Nodular

- Roxul's Rockfill

- Thermafiber's Spray Wool (one of many Granulated Products).

The stone wool insulation manufacturers were less interested in providing samples, emphasizing that their products were not developed for or supported if used in dense-pack retrofits in residential applications. BSC was able to collect sample bags from only one of the stone wool insulation manufacturers. To maintain anonymity, BSC will not identify the stone wool sample that they were able to collect and test. Appendix B includes manufacturer's literature for each of the products. 


\section{Experimental Apparatus and Method}

The dense-pack mineral fiber tests were performed using the same apparatus and method that were developed for the dense-pack cellulose fiber tests described by Schumacher (2011). The calibration box, electronic scale, test wall assembly, wall balance, and load cell were the same as those used for the cellulose testing in 2011. Only the fiber moving machine and installation methods were changed.

\subsection{Test Wall Assembly}

Figure 1 shows the test wall assembly and the two flow paths that are evaluated during testing: the short- and long-flow paths. A fan depressurizes the wall assembly so air is drawn in through the air inlet holes in the back panel. The top and bottom inlet holes are used for long path tests; the upper and lower inlet holes are used for short-path tests. The air travels through the densepacked insulation and out of the wall assembly at the air outlet slot that is located at mid-height on the front panel. The outlet air is collected in a manifold and drawn through a series of flow measurement devices before traveling through the fan and being expelled to the laboratory. This arrangement maximizes the uniformity of airflow, pressures, and temperatures.

A background leakage test is conducted with the top, bottom, upper and lower inlet holes sealed. The top and bottom holes are opened to produce two 45 1/4-in. long-flow paths. The top and bottom holes are then resealed and the upper and lower holes are opened to produce two 16-in. short-flow paths.

Airflow rates are reported in $\mathrm{cfm}_{50} / \mathrm{ft}^{2}$ where the area is perpendicular to the flow path. Each test involves flow paths up through three stud spaces and down through three stud spaces so the total flow area is $6 \times(3.5 \times 14.5$ in. $)=304.5$ in. $^{2}$.

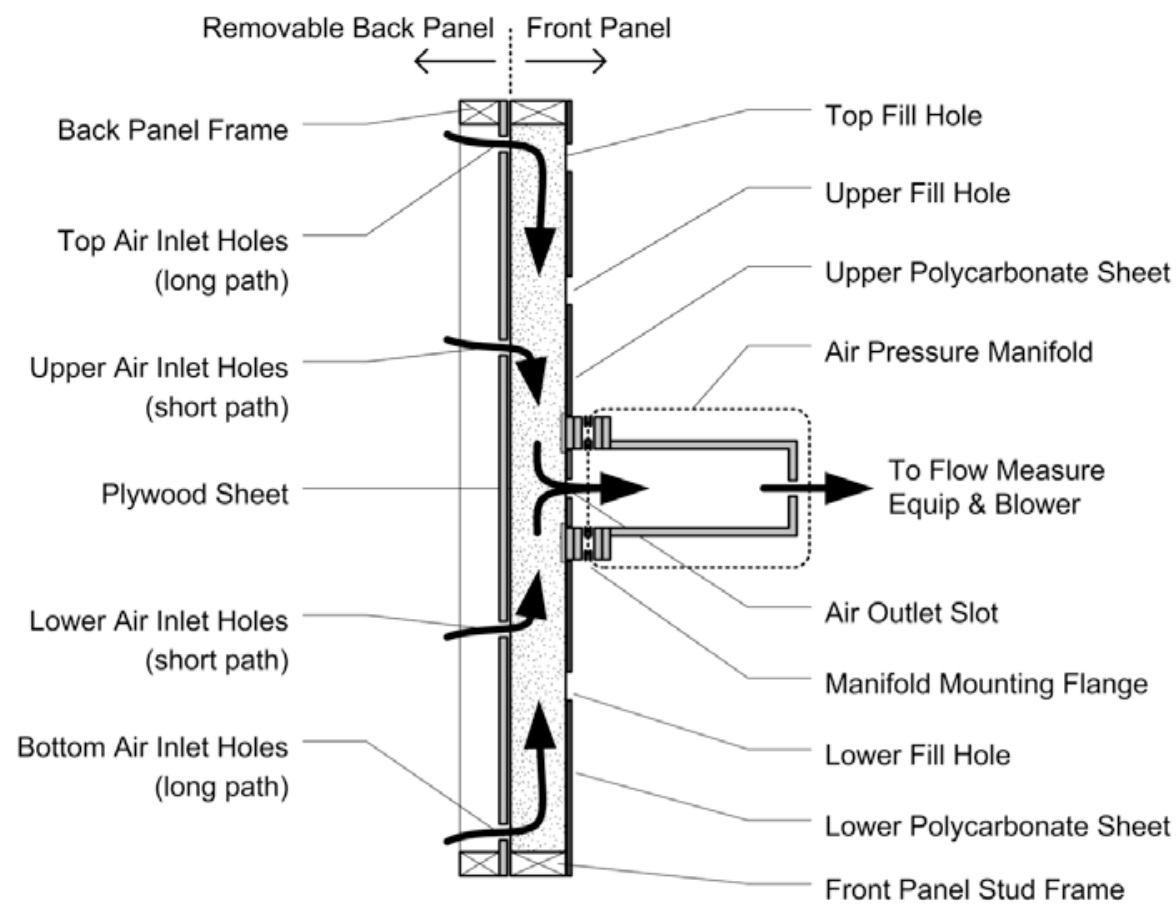

Figure 1. Schematic of airflow paths through test wall assembly 
The installed density is measured with an uncertainty of $\pm 1 \%$ or \pm 0.035 pcf. Air pressures are measured using an auto-zeroing digital manometer having a measurement accuracy of $\pm 1 \%$ of reading. Flow rates are measured using rotometers having uncertainty of $\pm 2 \%$ of reading and capable of measuring flow rates down to $5 \pm-0.6 \mathrm{scfh}$.

Schumacher (2011) provides more detailed explanation of the apparatus, test method, and uncertainty.

\subsection{Fiber Moving Machine}

A Krendl Model 450A All-Fiber Machine was used to prepare the cellulose fiber test wall specimens that Schumacher (2011) described. Several fiberglass test wall specimens had been prepared using this machine in 2011; however, the Krendl 450A did not have appropriate mixing paddles and shredders to properly condition the fiberglass material for dense-pack applications.

For the purposes of the mineral fiber dense-pack tests, BSC sought to identify and secure a single machine that could be used for all planned tests. The team approached members of a manufacturer experts' panel from the North American Insulation Manufacturers Association for input, and all agreed that the following small (i.e., portable, not truck-mount) machines were appropriate for dense-packing fiberglass insulation:

- Accul 9100 series

- Intec Force 3

- Krendl Model 425 or 475

- Spray Insulation Components InsulMaxx 2000 or 4000.

A brand new InsulMaxx 2000 machine, pictured in Figure 2, was secured for the preparation of fiberglass and stone wool test wall specimens. The InsulMaxx 2000 has a variable-speed blower, and double agitators (one set of shredders and one set of mixing paddles) suitable for conditioning fiberglass loose-fill products.

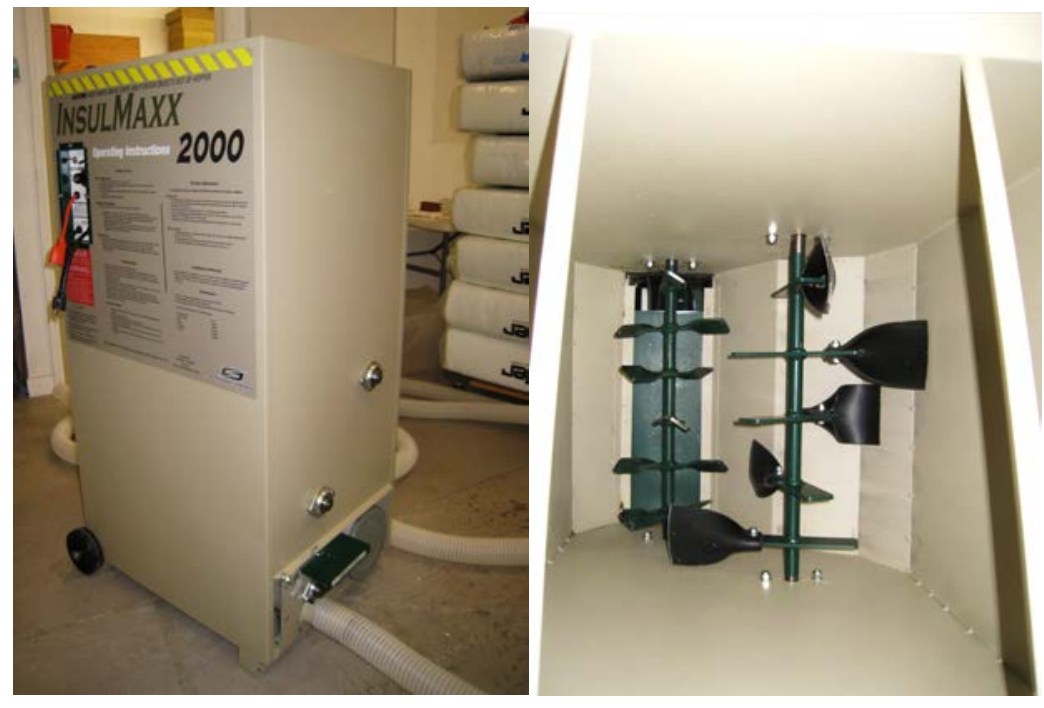

Figure 2. InsulMaxx 2000 all fiber machine (left) with double agitators (right) 


\subsection{Manufacturer-Recommended Installation Methods and Densities}

Cellulose insulation manufacturers provide few, if any, special instructions for installing their products in dense-pack retrofit applications. The installation instructions generally reflect those of BPI's Insulation and Airsealing Technician certification course. These requirements were summarized by Schumacher (2011). Appendix C of this report provides an example of one cellulose manufacturer's instructions for installing its product in a dense-pack retrofit application.

Fiberglass manufacturers, similarly, provide relatively little instruction for dense-pack retrofits. Table 1 provides a survey of the installation instructions and fill tables/coverage charts for each of the five loose-fill fiberglass insulation materials collected. The survey considered information on the product packaging and information readily available in the manufacturers' dense-pack and weatherization/retrofit literature. Table 2 provides a survey of the machine and hose recommendations for each of the five fiberglass materials. Finally, Table 3 provides a survey of the recommended installation methods/techniques for dense-pack and retrofit applications.

Only one of the five fiberglass products had packaging that included a dense-pack fill table. One other provided a fill table for "closed cavities that are compression filled," which implies densepack application. For these two products the package-recommended dense-pack install densities were 2.2 and $1.8 \mathrm{pcf}$, respectively. The other packages provided recommended install densities of 1.0-1.8 pcf for "closed cavities."

Where dense-pack installation instructions and fill tables are not provided on the packaging, it is reasonable for installers to seek this information online and from their local suppliers. References to dense-pack applications were found in the general documentation for four of the five products. Most documentation contained statements about the ability to dense pack to a certain density. Some documents said to install to "a minimum of" 2.5 pcf; others said install "up to" 2.5 pcf. Yet others suggested a range of dense-pack install densities (e.g., 1.8-2.6 pcf). In several cases, the recommended dense-pack install densities from the packages did not agree with the separate documentation.

Through discussions with installers, BSC found that some are using installation instructions and fill tables from manufacturers' weatherization and retrofit documentation. This documentation provides a third set of install densities that often contradict the information on the packaging and in other literature for the same product. The weatherization and retrofit documentation, where available, suggests install densities of 1.3-1.8 pcf for one product, $1.6 \mathrm{pcf}$ for another. A third product, Knauf EcoFill Wx, instructs weatherization installers to use dense-pack methods and fill to 2.2 pcf.

Loose-fill fiberglass insulation products perform differently from cellulose insulation products. Fiberglass products are expected to have dense-pack install densities that are different from and lower than those for cellulose materials. Furthermore, there may be a range of dense-pack install densities for different fiberglass products. 
Table 1. Survey of Dense-Pack and Retrofit Information for Loose-Fill Fiberglass Products

\begin{tabular}{|c|c|c|c|c|c|}
\hline Manufacturer & Certainteed & Guardian & Johns Manville & Knauf & $\begin{array}{c}\text { Owens } \\
\text { Corning } \\
\end{array}$ \\
\hline Product & Optima & CWI Plus & Spider & EcoFill Wx & ProPink L77 \\
\hline \multicolumn{6}{|c|}{ Package Information } \\
\hline Dense-Pack Instructions? & No & & No & Yes & No \\
\hline Dense-Pack Fill Table? & Yes $^{1}$ & Unknown $^{2}$ & $\mathrm{No}^{3}$ & $\mathrm{Yes}^{4}$ & \\
\hline Install Density & $\begin{array}{c}1.8 \text { pcf } \\
\text { "compression filled } \\
\text { closed cavities" }\end{array}$ & & $\begin{array}{l}1.0-1.8 \text { pcf } \\
\text { "spray applied and [Blown- } \\
\text { In Batt System] BIBS" }\end{array}$ & $\begin{array}{c}2.2 \text { pcf } \\
\text { "cavity wall" }\end{array}$ & $\begin{array}{l}1.3-1.8 \mathrm{pcf} \\
\text { "enclosed } \\
\text { cavity" }\end{array}$ \\
\hline \multicolumn{6}{|c|}{ Dense-Pack Documentation } \\
\hline $\begin{array}{c}\text { Instructions/Fill Tables } \\
\text { On-Line }\end{array}$ & Yes & Yes & Yes & Yes & Partial \\
\hline Document(s) & $\begin{array}{l}\text { Insulsafe } \\
\text { SP/Optima } \\
\text { Dense-Pack } \\
\text { Sell Sheet }\end{array}$ & $\begin{array}{c}\text { CWI Plus } \\
\text { Technical } \\
\text { Install Guide }\end{array}$ & $\begin{array}{c}\text { Spider } \\
\text { Dense-Pack } \\
\text { Sell Sheet; } \\
\text { Spec Sheet }\end{array}$ & $\begin{array}{l}\text { EcoFill WX } \\
\text { Fact Sheet }\end{array}$ & $\begin{array}{c}\text { ProPink L77 } \\
\text { Loose-Fill } \\
\text { Brochure; } \\
\text { Sell Sheet }\end{array}$ \\
\hline Install Density & $\begin{array}{l}\text { Min. } 2.5 \text { pcf } \\
\text { "dense-pack" }\end{array}$ & $\begin{array}{c}2.2 \text { pcf } \\
\text { "dense-pack" }\end{array}$ & $\begin{array}{c}1.8-2.6 \text { pcf } \\
\text { "dense-pack" }\end{array}$ & $\begin{array}{c}2.2 \text { pcf } \\
\text { "dense-pack" }\end{array}$ & $\begin{array}{l}\text { "up to" } 2.5 \text { pcf } \\
\text { "dense-pack" }\end{array}$ \\
\hline \multicolumn{6}{|c|}{ Weatherization/Retrofit Documentation } \\
\hline $\begin{array}{c}\text { Instructions/Fill Tables } \\
\text { On-Line }\end{array}$ & Yes & None Found & None Found & Yes & Yes \\
\hline Document(S) & $\begin{array}{l}\text { Optima Sidewall } \\
\text { Reinsulation } \\
\text { Spec Sheet }\end{array}$ & & & $\begin{array}{l}\text { EcoFill WX } \\
\text { Data sheet } \\
\text { (BW-DS-08); }\end{array}$ & $\begin{array}{c}\text { ProPick L77 } \\
\text { Loose Fill } \\
\text { Insulation Fact } \\
\text { Sheet }\end{array}$ \\
\hline Install Density & $\begin{array}{c}1.6 \mathrm{pcf} \\
\text { "sidewall } \\
\text { reinsulation" }\end{array}$ & & & $\begin{array}{c}2.2 \text { pcf } \\
\text { "cavity wall", }\end{array}$ & $\begin{array}{c}1.3-1.8 \text { pcf } \\
\text { "closed } \\
\text { cavity wall" }\end{array}$ \\
\hline
\end{tabular}

\footnotetext{
${ }^{1}$ Certainteed Optima packaging provides a coverage chart only for "closed cavities that are compression filled."

${ }^{2}$ Guardian CWI Plus product packaging was unavailable at time of testing; correct product was provided in European Union packaging; North American package information unknown.

JM Spider packaging provides instructions and tables for Blown-In Batt System applications; weatherization contractors familiar with cellulose often consider netted installations (such as Blown-In Batt System) to employ dense-pack techniques and densities.

${ }^{4}$ Knauf EcoFill WX package provides machine settings for dense-pack and a fill table for "Cavity Wall Application."
} 
Table 2. Survey of Machine and Hose Recommendations for Dense-Pack and Retrofit Applications Using Loose-Fill Fiberglass Products

\begin{tabular}{|c|c|c|c|c|c|}
\hline Manufacturer & Certainteed & Guardian & $\begin{array}{c}\text { Johns } \\
\text { Manville }\end{array}$ & Knauf & $\begin{array}{c}\text { Owens } \\
\text { Corning }\end{array}$ \\
\hline Product & Optima & CWI Plus & Spider & EcoFill Wx & $\begin{array}{l}\text { ProPink } \\
\text { L77 }\end{array}$ \\
\hline \multicolumn{6}{|c|}{ Blowing Machine Recommendations } \\
\hline $\begin{array}{c}\text { General } \\
\text { Requirements }\end{array}$ & $\begin{array}{l}\text { Fiber agitation and } \\
\text { conditioning with } \\
\text { pressure control }\end{array}$ & $\begin{array}{l}\text { Stewart } 1000,750,500 \text {, and } 350 ; \\
\text { InsulMaxx 5000, 4000, and 2000; } \\
\text { Force/2, Force/3, and Wasp; } \\
\text { Krendl } 1000,1300,2000,2300\end{array}$ & $\begin{array}{l}\text { None } \\
\text { provided }\end{array}$ & $\begin{array}{l}\text { Example Machines: } \\
\text { Large: Volumatic III } \\
\text { Medium: Krendl } 2300 \\
\text { Small: Force II } \\
\text { and WASP }\end{array}$ & $\begin{array}{l}\text { None } \\
\text { provided }\end{array}$ \\
\hline Speed & $\begin{array}{c}\text { Per machine } \\
\text { manufacturer's } \\
\text { recommendations }\end{array}$ & & & & \\
\hline Slide Gate & $1 / 3-1 / 2$ open & $\begin{array}{c}75 \% \\
\text { of position for a "typical attic job" }\end{array}$ & & 4-4.5 in. open & \\
\hline $\begin{array}{c}\text { Air Pressure@ End } \\
\text { of Hose or Insertion } \\
\text { Tube }\end{array}$ & $\begin{array}{c}2-2.4 \mathrm{psi} \\
55-66 \text { in. } \mathrm{H} 20\end{array}$ & & & $\begin{array}{c}2 \text { psi } \\
55 \text { in. } \mathrm{H} 20\end{array}$ & \\
\hline Acceptable Feed Rate & & & & $5-35 \mathrm{lb} / \mathrm{min}$ & \\
\hline \multicolumn{6}{|c|}{ Blowing Hose Recommendations } \\
\hline $\begin{array}{c}\text { General } \\
\text { Requirements }\end{array}$ & $\begin{array}{l}\text { Internally corrugated } \\
\text { with smooth } \\
\text { transition reducers }\end{array}$ & & $\begin{array}{l}\text { None } \\
\text { Provided }\end{array}$ & $\begin{array}{l}\text { Min. } 1 / 4 \text { in. internal } \\
\text { corrugations }\end{array}$ & $\begin{array}{c}\text { None } \\
\text { Provided }\end{array}$ \\
\hline 1st Section & $\begin{array}{l}\text { Min. } 100 \mathrm{ft} \text { of } 2.5 \mathrm{in} . \\
\text { ID* }\end{array}$ & Min. $50 \mathrm{ft}$ of 2.5 in. ID & & Min. $150 \mathrm{ft}$ & \\
\hline 2nd Section & $50 \mathrm{ft}$ of 2 in. ID & $50 \mathrm{ft}$ of 2 in. ID & & & \\
\hline 3rd Section & $\begin{array}{l}10-25 \mathrm{ft} \text { of } 1.5 \mathrm{in} . \\
\text { ID }\end{array}$ & Min. $10 \mathrm{ft}$ of $1.5 \mathrm{in} . \mathrm{ID}$ & & & \\
\hline Insert Tube & $\begin{array}{c}10 \mathrm{ft} \text { of } 1.25-1.5 \mathrm{in} . \\
\text { ID }\end{array}$ & $10 \mathrm{ft}$ of $1-1.5 \mathrm{in} . \mathrm{ID}$ & & Min. 1 in. ID & \\
\hline
\end{tabular}

* Inside diameter 
Table 3. Survey of Recommended Dense-Pack and Retrofit Techniques for Loose-Fill Fiberglass Products

\begin{tabular}{|c|c|c|c|c|c|}
\hline $\begin{array}{c}\text { Manufacture } \\
\mathbf{r} \\
\end{array}$ & Certainteed & Guardian & $\begin{array}{c}\text { Johns } \\
\text { Manville }\end{array}$ & Knauf & $\begin{array}{l}\text { Owens } \\
\text { Corning }\end{array}$ \\
\hline Product & Optima & CWI Plus & Spider & EcoFill Wx & ProPink L77 \\
\hline \multicolumn{6}{|c|}{ Dense-Pack Techniques } \\
\hline Preferred & $\begin{array}{l}\text { Insertion tube upward } \\
\text { through } 1 \text { lower hole }\end{array}$ & $\begin{array}{l}\text { Insertion tube upward } \\
\text { through } 1 \text { lower hole }\end{array}$ & None provided & None provided & None provided \\
\hline Alternative 1 & $\begin{array}{l}\text { Insertion tube downward } \\
\text { through } 1 \text { top hole }\end{array}$ & $\begin{array}{l}\text { Insertion tube downward } \\
\text { through } 1 \text { top hole }\end{array}$ & & & \\
\hline Alternative 2 & $\begin{array}{l}\text { Insertion tube through } 2 \\
\text { holes: upper and lower }\end{array}$ & $\begin{array}{c}\text { Nozzle through } \\
3 \text { holes (drill and fill) }\end{array}$ & & & \\
\hline \multicolumn{6}{|c|}{ Retrofit Techniques } \\
\hline Method 1 & $\begin{array}{c}\text { Directional nozzle through at } \\
\text { least two holes: } \\
3 \mathrm{ft} \text { above bottom } \\
+2 \mathrm{ft} \text { below top }\end{array}$ & None provided & None provided & None provided & None provided \\
\hline Method 2 & $\begin{array}{l}\text { Insertion tube through hole at } \\
\text { mid-height }\end{array}$ & & & & \\
\hline
\end{tabular}


Only one of the five materials collected had consistent instructions and recommended install densities between the packaging, dense-pack documentation and weatherization retrofit documentation. In all other cases, the installer is faced with a range of instructions and install densities to work toward. Greater clarity and consistency are needed in the installation instructions and recommended install densities for fiberglass products used in dense-pack retrofit applications.

\subsection{Installation Methods and Densities for Test Wall Specimens}

The experimental program for this work was modified to address the range of installation methods and install densities provided on the material packaging and in other documentation from the five loose-fill fiberglass insulation manufacturers. None of the stone wool insulation manufacturers support dense-pack applications, so none provided any directions or target densities for this application. The same insulation techniques and target densities were used for fiberglass and stone wool products.

The InsulMaxx 2000 machine was set up with $150 \mathrm{ft}$ of internally corrugated hose with smooth transitions down to either a 2 -in. ID nozzle or an 8-ft. long, 1-1/4-in. ID insertion tube. Test wall specimens were prepared using three installation methods:

- Bottom fill. The insertion tube was fed into the cavity, upward through one lower hole and drilled at approximately 24 in. above the bottom plate, until it was approximately 6 in. from the top of the cavity. The cavity was filled with insulation and the tube was slowly withdrawn as the cavity filled, the material compressed, and the feed rate slowed. This method most closely reflects the install method used for dense-packing cellulose. However, to achieve the lower densities recommended for fiberglass materials, the tube must be removed before the material flow comes to a complete stop and, unlike cellulose dense-packing, the tube is not pulled out and pushed part way back in.

- Top fill. The insertion tube was fed into the cavity, downward through one top hole and drilled at approximately 6 in. below the top plates, until it was approximately 6 in. from the bottom of the cavity. The cavity was filled with insulation and the tube was slowly withdrawn as the cavity filled, the material compressed, and the feed rate slowed.

- Two-inch nozzle. The cavity was filled with a 2-in. ID nozzle, using a "two-hole" or "three-hole" approach. The nozzle was introduced first through a lower hole and drilled at approximately $24 \mathrm{in}$. above the bottom plate. Insulation was filled first downward and then upward until it reached the level of an upper hole and drilled at approximately 24 in. below the top plates. The nozzle was then moved to the upper hole and insulation was filled upward until it reached the top of the cavity. When using the "three-hole" variation, the nozzle was inserted into the top hole and drilled approximately 6 in. below the top plates. Then material was added until the insulation was slightly packed.

The fiberglass insulation packaging and other documentation suggest a range of installation densities covering 1.0-2.6 pcf. BSC set out to prepare test wall specimens to address everything from median densities recommended for weatherization/retrofit/reinsulation applications (e.g., 1.5-1.8 pcf) to the higher densities clearly intended for dense-pack (e.g., 2.2-2.6 pcf) and even into higher fiberglass dense-pack densities reported by some installers (e.g., 3.0 pcf). BSC 
intentionally avoided the lowest densities listed in "closed cavity" fill tables on packaging (e.g., 1.0 to $<1.5 \mathrm{pcf}$ ), expecting that they would not provide any effective airflow resistance.

\subsection{Other Experimental Methods}

Other aspects of the test wall specimen preparation and airflow resistance testing followed the procedures summarized by Schumacher (2011). Installation techniques were refined and machine settings were established using the same density box method that was used for the previous cellulose tests. The installed material density was established using the same apparatus and methods as used for the cellulose tests. Finally, the background air leakage, short-path airflow test, and long-path airflow tests were conducted using the same equipment and methods as used for the cellulose tests. 


\section{Results and Discussion}

This section provides a summary of airflow resistance test results for select fiberglass and stone wool insulation materials.

\subsection{Test Program}

Three loose-fill fiberglass insulation products were randomly selected from the five collected. Only one stone wool product was collected and tested. Only Building Science Laboratories staff know which manufacturers' materials were used in the testing; the reporting is done using material codes (e.g., tests A1, A2, and A3 represent tests 1, 2, and 3 conducted using materials from manufacturer A). This reporting method was also used in the cellulose tests reported by Schumacher (2011). To avoid confusion with the previously completed cellulose test results, the three fiberglass materials tested were designated with letters $\mathrm{O}, \mathrm{P}$, and Q; the lone stone wool product was designated with letter R.

Test wall specimens were prepared to cover the range of densities identified on the packaging and in other documentation: roughly $1.8-2.5 \mathrm{pcf}$.

\subsection{General Airflow Test Results}

Roughly 16 fiberglass test wall specimens and three stone wool test wall specimens were prepared and tested.

\subsubsection{Long- and Short-Path Airflow Test Results}

Table 4 provides a summary of the test results for the four MFI products (three fiberglass and one stone wool) that were evaluated in this project. The highest and lowest measured flow rates are reported for each material along with the install density that was associated with each flow rate. For purposes of comparison, the table also includes the highest and lowest measured test results for the cellulose materials that were evaluated in 2011. Finally, the table includes the CFI benchmark flow rates recommended by Schumacher (2011).

Table 4. Summary of Mineral Fiber Test Results With Comparison to Previous Cellulose Tests

\begin{tabular}{|c|c|c|c|c|c|c|c|c|c|c|}
\hline & \multicolumn{2}{|c|}{$\begin{array}{l}\text { Material O } \\
\text { (fiberglass) }\end{array}$} & \multicolumn{2}{|c|}{$\begin{array}{l}\text { Material P } \\
\text { (fiberglass) }\end{array}$} & \multicolumn{2}{|c|}{$\begin{array}{l}\text { Material Q } \\
\text { (fiberglass) }\end{array}$} & \multicolumn{2}{|c|}{$\begin{array}{c}\text { Material R } \\
\text { (stone wool) }\end{array}$} & \multicolumn{2}{|c|}{$\begin{array}{c}\text { Materials A-J } \\
\text { (cellulose) }\end{array}$} \\
\hline & $\mathrm{cfm}_{50} / \mathrm{ft}^{2}$ & pef & $\mathrm{cfm}_{50} / \mathrm{ft}^{2}$ & pef & $\mathrm{cfm}_{2} / \mathrm{ft}$ & pcf & $\mathrm{cfm}_{50} / \mathrm{ft}^{2}$ & pef & $\mathrm{cfm}_{50} / \mathrm{ft}^{2}$ & pef \\
\hline \multicolumn{11}{|c|}{ Long-Path Airflow } \\
\hline High & 2.6 & 2.0 & 1.2 & 1.5 & 1.7 & 2.2 & 1.3 & 3.1 & 0.45 & 3.4 \\
\hline "Benchmark" & & & & & & & & & 0.33 & 3.5 \\
\hline Low & 0.42 & 2.3 & 0.28 & 2.0 & 0.62 & 2.7 & 0.67 & 4.1 & 0.12 & 3.7 \\
\hline \multicolumn{11}{|c|}{ Short-Path Airflow } \\
\hline High & 6.8 & 2.0 & 4.1 & 1.7 & 4.7 & 2.2 & 4.8 & 3.1 & 1.3 & 3.5 \\
\hline "Benchmark" & & & & & & & & & 1.0 & 3.5 \\
\hline Low & 1.1 & 2.3 & 0.76 & 2.3 & 1.8 & 2.7 & 2.0 & 4.1 & 0.37 & 3.7 \\
\hline
\end{tabular}

When installed to higher densities (e.g., approximately 2.3-2.7 pcf) two of the three fiberglass insulation materials $(\mathrm{O}$ and $\mathrm{P}$ ) produced long-path airflow test results that were comparable with the cellulose insulation long-path airflow test results obtained by Schumacher in 2011. That 
testing established long- and short-path airflow "benchmarks" of 0.33 and $1.0 \mathrm{cfm}{ }_{50} / \mathrm{ft}^{2}$, respectively, for historical dense-pack cellulose retrofits installed to $3.5 \mathrm{pcf}$. Again, when installed to higher densities (e.g., higher than approximately $2.3-2.7 \mathrm{pcf}$ ), two of the fiberglass insulation materials $(\mathrm{O}$ and $\mathrm{P})$ produced short-path airflow test results that were comparable with the cellulose insulation short-path airflow test results obtained in 2011. The measured performance of the fiberglass test wall specimens depended highly on the material tested and the installation method. These issues are discussed further in Section 3.3 of this report.

The long- and short-path airflow tests for the stone wool insulation resulted in airflow rates that were 1.5-2 times higher than the cellulose tests, despite the fact that the stone wool was installed at higher densities (e.g., 3.1-4.1 pcf).

\subsubsection{Flow Regime and Pressure Range}

Dense-pack fiber insulation provides significant resistance to the flow of air. When the fibers completely fill a stud bay or other framed cavity, air must flow through the fiber matrix rather than through open voids. The resulting airflow should be laminar and, if data regression is performed assuming a power law relationship, the flow exponent (n) should be close to 1 .

Figure 3 plots the flow exponents calculated for the background leakage (blue squares in lower part of plot), long-flow path (red squares in upper part of plot) and short-flow path (green triangles in upper part of plot) tests for each of the mineral fiber test wall specimens. For all but one of the long- and short-flow path tests, the flow exponent is 0.9 or higher, suggesting that laminar flow is dominant and that the dense-pack fiber insulation largely eliminates open voids that would permit higher airflow rates. Figure 4 shows the same plot for the CFI tests that were conducted in 2011. The flow exponents for the long- and short-flow path tests of the cellulose test wall assemblies are slightly higher.

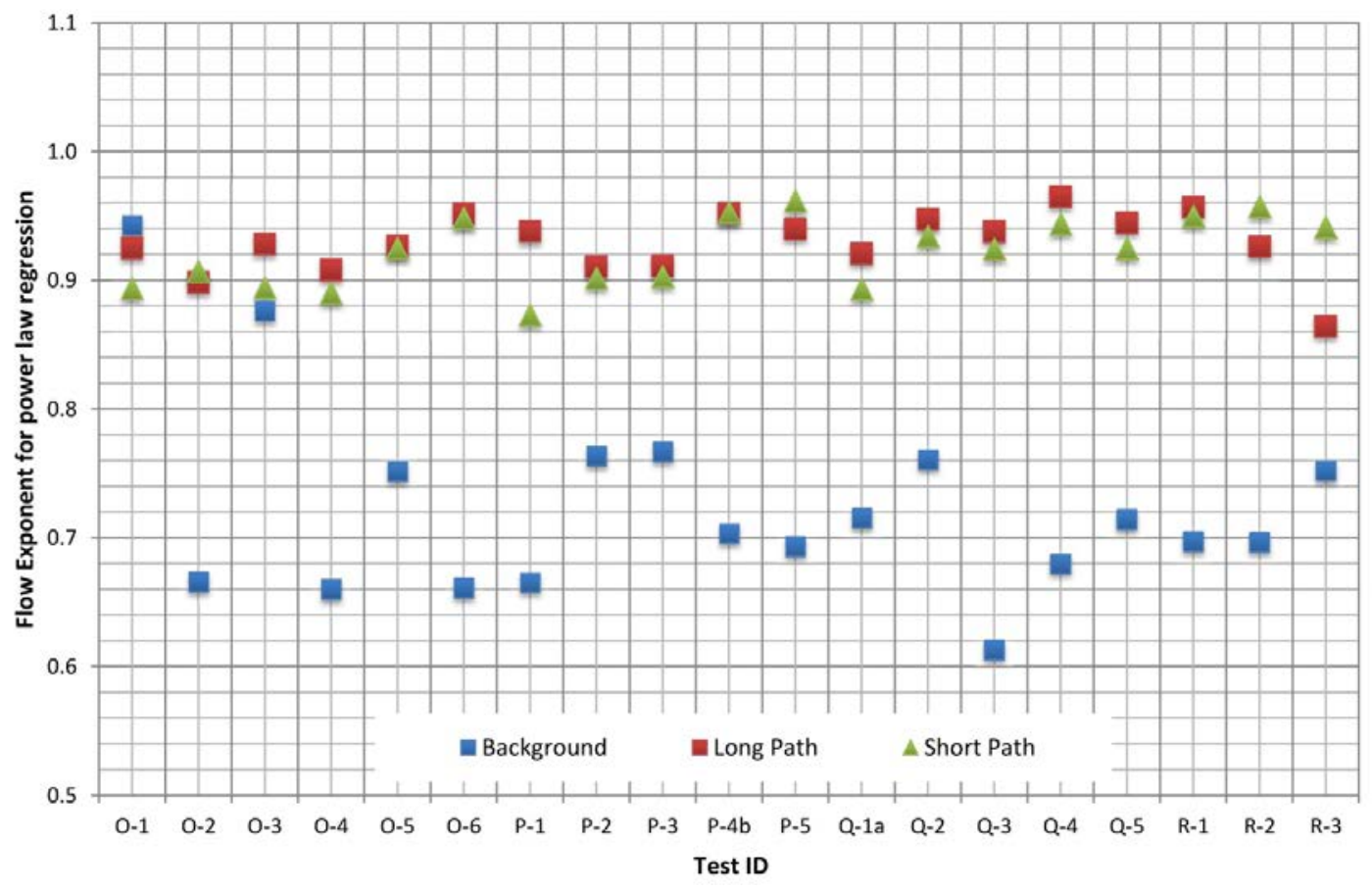


Figure 3. Flow exponents for all MFI tests

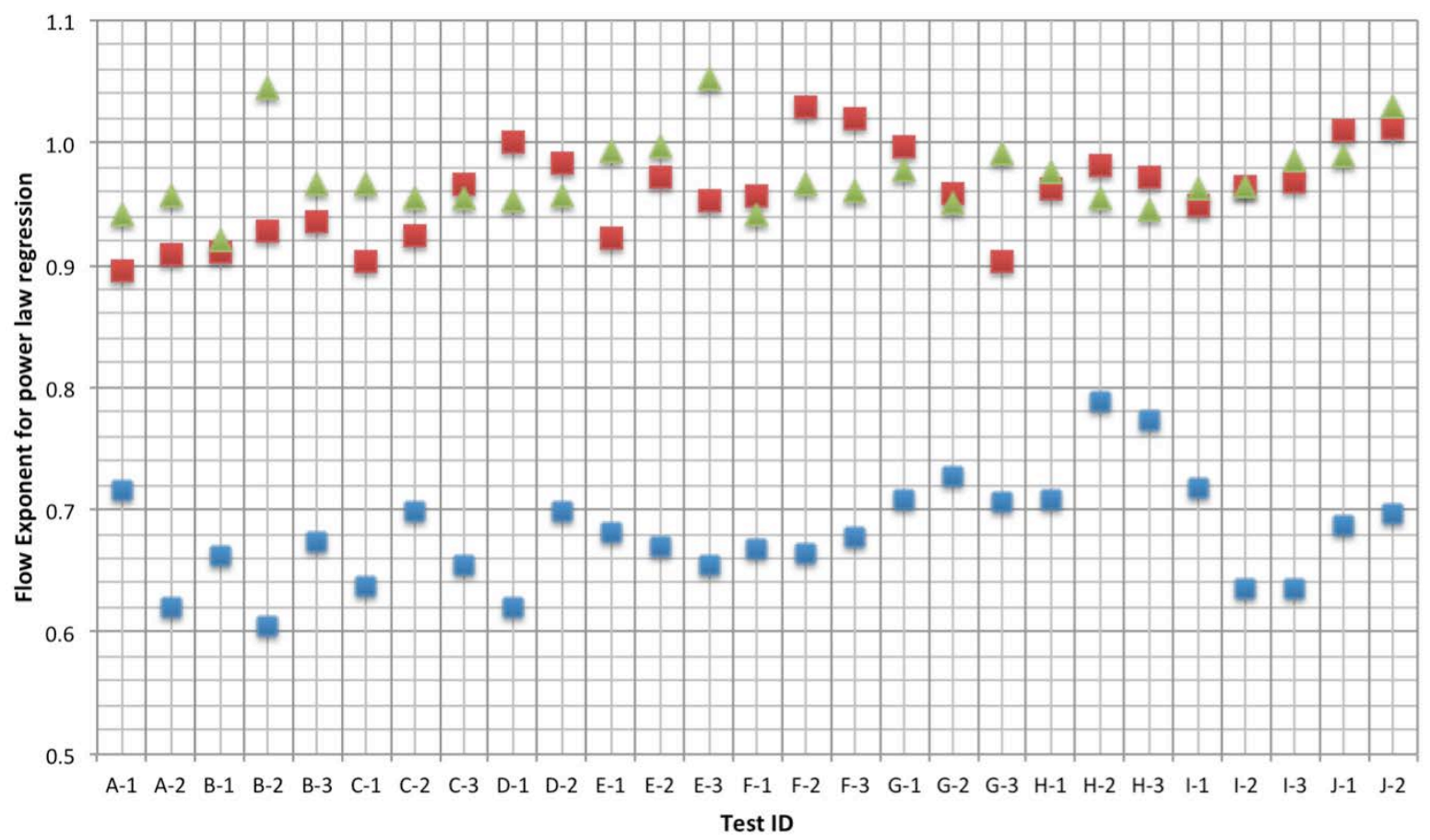

Figure 4. Flow exponents for previous CFI tests

(Schumacher 2011)

\subsection{Influence of Material and Installation Method}

This section discusses the individual airflow test results for the three fiberglass and one stone wool materials tested. The influences of material and installation method are addressed.

\subsubsection{Material O}

Density box specimens for Material $\mathrm{O}$ were first prepared using the bottom fill installation method. However, BSC was unable to produce acceptable specimens with densities lower than 2.8-3.2 pcf. When lower test specimen densities were achieved using this method, the material was clearly not evenly distributed. For this reason, the team opted not to produce any full test wall specimens using the bottom fill method; but instead, sought to produce test wall specimens with densities of 1.8-2.5 pcf, using the top fill and 2-in. nozzle installation methods.

The long-path airflow data for the six Material $\mathrm{O}$ tests are presented in Figure 5. Four of the Material $\mathrm{O}$ airflow tests were performed on samples installed using the top fill installation method (i.e., using the 8 -ft insertion tube through the top installation hole). The remaining two airflow tests were performed on samples installed using just the 2 -in. nozzle method (i.e., installed through the lower, upper, and top access holes on the front of the test apparatus). 


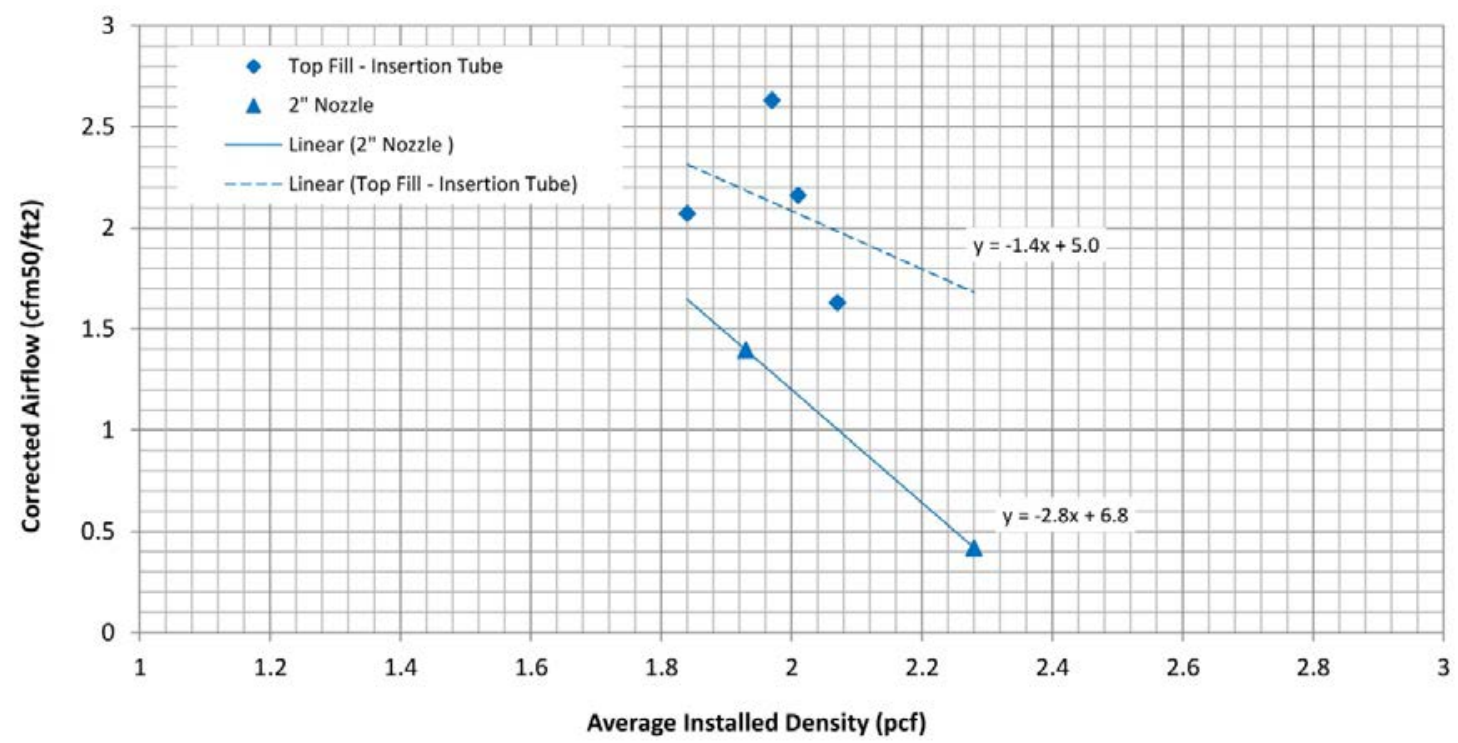

Figure 5. Material O: long-path airflow rest results versus installed density and installation method

The data presented in Figure 5 indicate that a wide range of airflow rates are possible for densities of 1.8-2.1 pcf. The airflow data from the insertion tube installations (O-1 to O-4, represented by the diamond-shaped markers) suggest a low correlation between airflow rate and density. Pockets of higher and lower density were visible in the test wall assemblies installed using the insertion tube method. The same observations were made when the CFI test specimens were prepared in 2011; however, density variations are believed to have less impact on airflow because the overall installed density of the CFI specimens was higher ( $3.5 \mathrm{pcf}$ for CFI versus 1.8-2.2 pcf for MFI. Lower airflow rates and tighter standard deviation might be achieved if MFI specimens were installed to higher densities using the insertion tube method (whether it is bottom fill or top fill).

The lowest airflow rates for Material $\mathrm{O}$ were achieved using the 2-in. nozzle to fill the cavity through all three installation ports.

The distribution of the insulation within the stud cavity was assessed by determining the difference between the long-path and short-path flow exponents. These flow exponents indicated that the 2-in. nozzle resulted in a more uniform density distribution. The average difference between the long- and short-path flow exponent values was 0.023 for the insertion tube and 0.003 for the 2-in. nozzle. The flow exponent data for each test are presented in Figure 3.

\subsubsection{Material $\boldsymbol{P}$}

The long-path airflow data for the five Material $\mathrm{P}$ tests are presented in Figure 6. Four Material $\mathrm{P}$ test wall samples were prepared using the insertion tube methods ( 2 bottom fill and 2 top fill). The insulation for tests P-1 and P-2 (represented by the diamond-shaped markers) was installed using the top fill method while the bottom fill method was used for tests P-3 and P4 (represented by the square markers). The insulation for the P-5 test was installed using the 2-in. nozzle method and all three installation holes (lower, upper, and top) on the front of the test apparatus. 


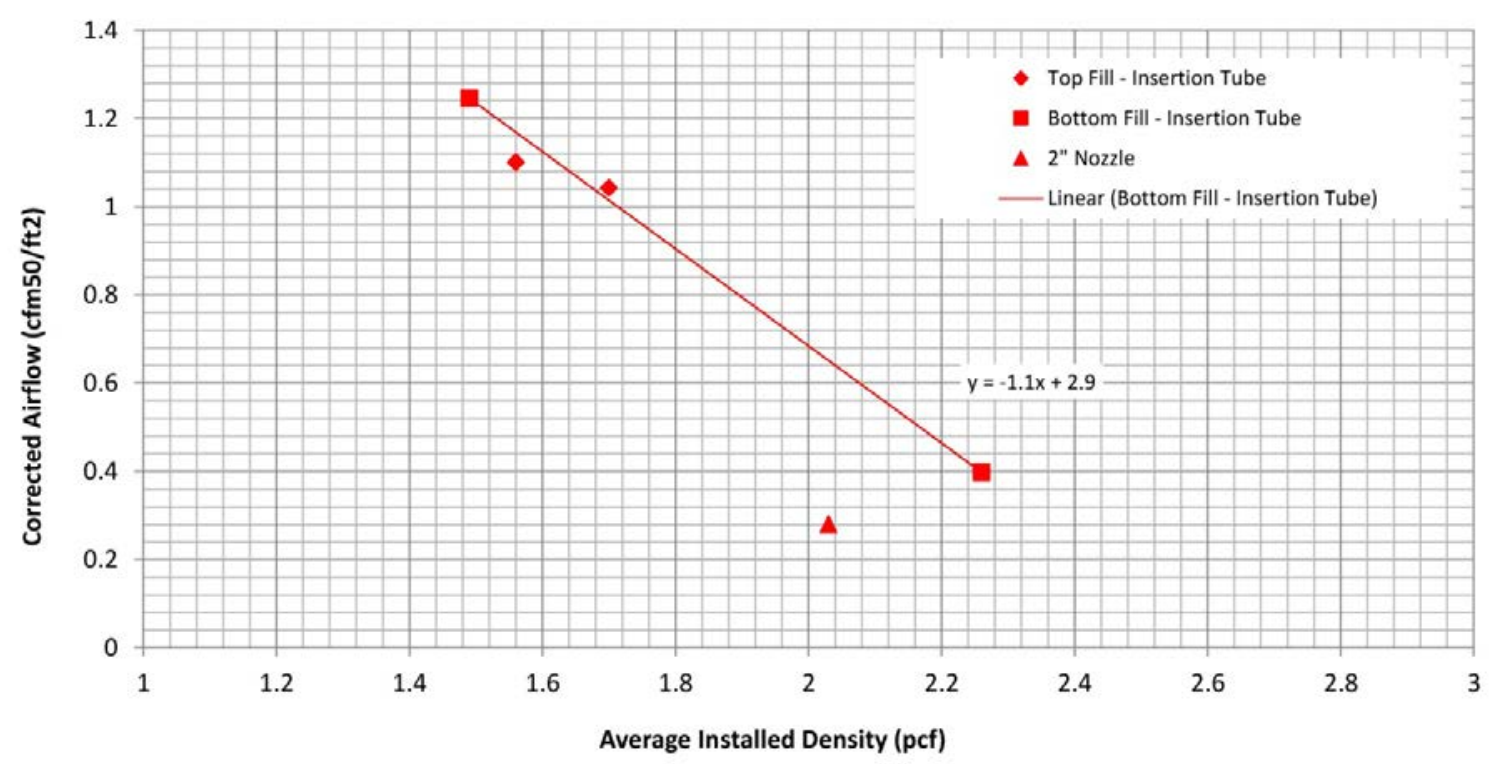

Figure 6. Material P: long-path airflow rest results versus installed density and installation method

The data presented in Figure 6 indicate a well-defined correlation between airflow and installed density for Material P. The regression analysis defines the relationship between airflow and density with a high degree of confidence for Material $\mathrm{P}$. The slope of the regression line for the insertion tube installations was determined to be $-1.1 \mathrm{cfm}_{50} \cdot \mathrm{ft} / \mathrm{lb}$ with an $\mathrm{R}^{2}$ of 0.99 . Because there was a high degree of correlation between airflow and density, only one test was performed on Material P using the 2-in. nozzle installation, which yielded the lowest airflow performance for Material P. The air leakage test performed on the 2-in. nozzle installation determined the lowest measured long-path airflow rate $\left(0.280 \mathrm{cfm}_{50} / \mathrm{ft}^{2}\right.$ at $\left.2.03 \mathrm{pcf}\right)$ of all the material data sets.

The difference between the long-path and short-path flow exponents varied between 0.001 and 0.065 for the insertion tube installations ( 0.021 on average) and 0.022 for the 2 -in. nozzle. The data in Figure 3 show that with the exception of P-1, the insertion tube installations produced uniform density distributions within the stud cavity.

\subsubsection{Material Q}

Figure 7 presents the long-path airflow data for the five Material Q test wall specimens. Three of the Material Q airflow tests were performed on test wall specimens prepared using the 8-ft. insertion tube, one using the top fill method (Q-3) and two using the bottom fill method (Q-1, Q2). The remaining two airflow tests were performed on specimens installed using the 2 in. nozzle (Q-4, Q-5). The average installed density for Material Q tended to be higher than for other fiberglass products using similar installation methods. Overall, the average installed density was 2.3 pcf for both the insertion tube and 2-in. nozzle methods. The lowest airflow rates were achieved using the 2-in. nozzle installation method. 


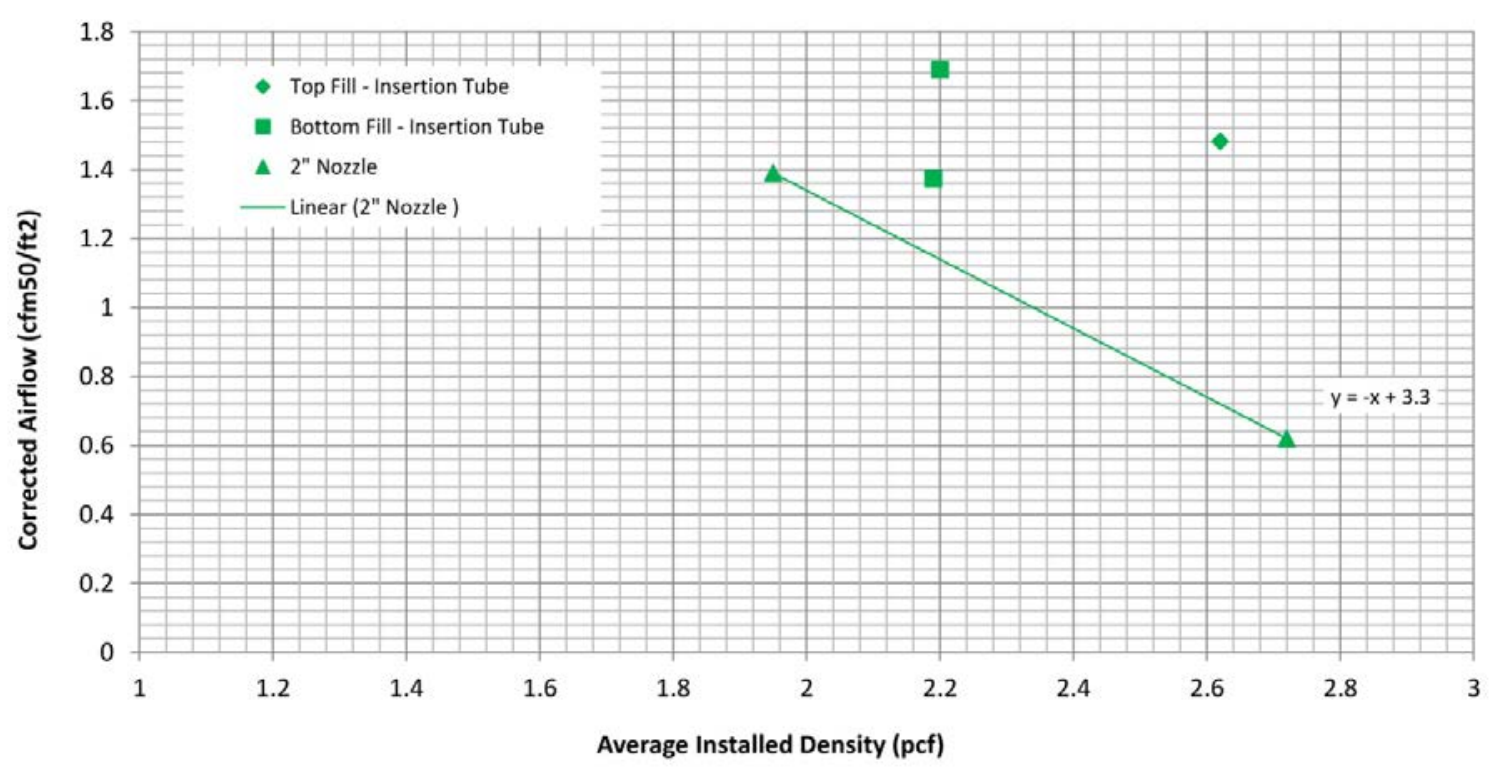

Figure 7. Material Q: long-path airflow rest results versus installed density and installation method

The data presented in Figure 7 indicate a well-defined correlation between airflow and installed density for Material Q when installed using the 2-in. nozzle; no correlation was observed in the insertion tube data. Better airflow performance might be observed if higher install densities had been sought using the insertion tube method.

The regression analysis of the 2-in. nozzle data could not be defined with any degree of confidence because of the limited sample size (two); however, the slope of the regression line was determined to be $-1.0 \mathrm{cfm}_{50} \cdot \mathrm{ft} / \mathrm{lb}$, which compared well with the other data sets, as summarized in Table 4.

The difference between the long- and short-path flow exponents varied between 0.013 and 0.027 for the insertion tube installations and averaged 0.02 for the 2-in. nozzle. As shown by the flow exponents presented in Figure 3, the insulation density of the Material Q test cavities was moderately well distributed relative to the other Material types. The flow exponent data also indicate that the installation method had a limited effect on density distribution.

\subsubsection{Material $R$}

The stone wool product designated Material $\mathrm{R}$ was not specifically designed for dense-pack retrofit applications. Through the density box calibration work, BSC found it impossible to move the fiber nodules through the 1.25-in. ID insertion tube; the hose constantly plugged. As a result, BSC was only able to prepare test wall specimens using the 2-in. nozzle method. Further, the team was unable to produce test wall specimens with densities lower than approximately 3.0 pcf. As a result, the average installed densities for the stone wool test walls were considerably higher than those produced using any of the fiberglass materials included in this study.

Finally, the stone product contained a considerable amount of fine to coarse, non-fibrous material (i.e., "shot") that BSC thought was too abrasive and likely to cause accelerated wear on 
the fiber-moving equipment in dense-pack retrofit applications. The number of airflow tests performed on this sample was limited to three because this product is highly abrasive.

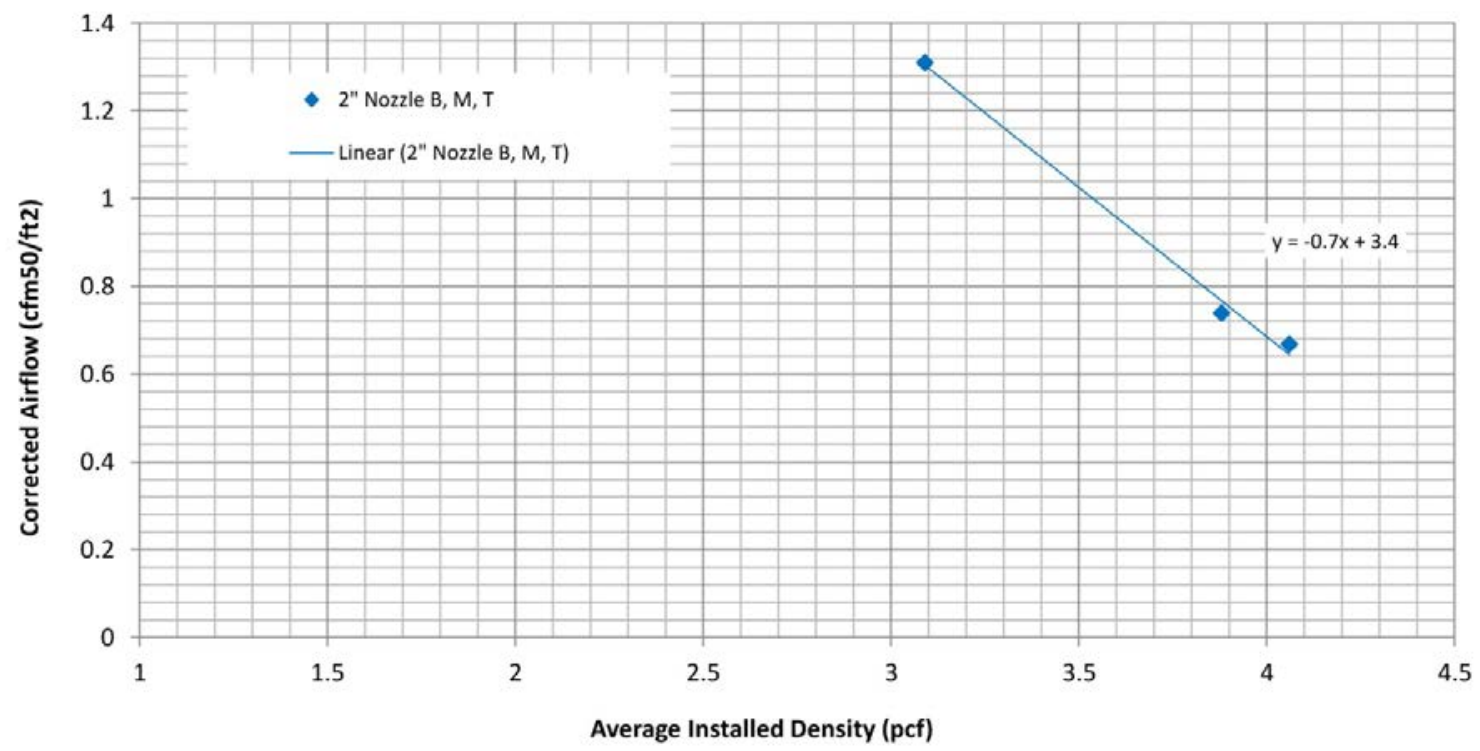

Figure 8. Material R: long-path airflow rest results versus installed density and installation method

Data from the airflow tests performed on this material demonstrated a consistent increase in airflow resistance with density; these data are presented in Figure 8. In light of the small data set, the slope of the regression line indicates that the airflow through this material changes at a rate of $-0.7 \mathrm{cfm}_{50} \cdot \mathrm{ft} / \mathrm{lb}$. This number compares well with the regression slopes observed in the fiberglass samples that were installed using the 2-in. nozzle; however, the densities are significantly higher. The lowest airflow rates for Material $\mathrm{R}$ were achieved with densities of 3.9 and $4.1 \mathrm{pcf}$. The corrected airflow rates associated with each of these densities were 0.74 and $0.67 \mathrm{cfm}{ }_{50} / \mathrm{ft}^{2}$, respectively.

These results also indicate that the resistance to airflow increases more slowly with density than what was observed in the fiberglass samples. This relationship may change if testing was completed using a more refined mineral wool product without the non-fibrous material (i.e., various sizes of solidified blobs or balls of molten rock, referred to as shot).

\subsubsection{Installation Methods}

Based on manufacturers' instructions on packaging and in other documentation, three installation methods were tested. The installation experience and airflow test results collected under laboratory conditions suggest that the 2-in. nozzle installation method results in more even material distribution and lower long- and short-path airflow rates (i.e., higher airflow resistance) than either of the insertion tube methods (i.e., top or bottom). Also, many installers are familiar with nozzle installation methods because they are commonly used for installing cellulose fiber or fiberglass insulation in netted-and-blown installations (e.g., Blown-In Batt System).

However, in netted-and-blown applications installers can easily see the "fill" of the cavity space through the netting and assess distribution and density by touch (i.e., by pushing on the netting). In netted-and-blown applications cavity spaces can be filled completely and to sufficient density 
to minimize the potential for settling. In retrofit applications, loose-fill insulation materials are installed in existing cavities that are bounded by opaque, stiff materials (e.g., framing, sheathing, plaster, wall board) so the installer can neither see into the cavity space to assess fill nor touch the surface of the insulation to assess distribution and density. The insertion tube installation methods were (in part) developed to address these problems.

Weatherization contractors and dense-pack installers are trained to understand different framing methods and to site-assess framing conditions to identify obstructions (e.g., blocking) that might prevent all cavities from being completely filled with insulation. Insertion tubes are graduated (i.e., typically marked at 1-ft intervals). Installers are taught to use the insertion tube to "probe" the bounds of cavities to identify obstructions as they are installing. The insertion tube is pushed to the furthest reaches of the cavity to confirm that dimensions are as expected. The insertion tube is withdrawn only a few inches before starting to fill the cavity. This ensures that insulation is delivered to the far end of the cavity without catching on partial obstructions and creating an uninsulated space or pocket, as is possible when using a nozzle installation method.

Some installers use the nozzle installation method for dense-pack retrofit applications. This testing supports the belief that good airflow resistance can be achieved using the nozzle installation method. However, given the realities discussed in the previous paragraph, insertion tube installation methods should be considered a best practice for retrofit applications. If the only goal of an insulation retrofit is to fill cavities with insulation, insertion tube installation methods should be recommended and lower density installs can be accepted (assuming density is sufficient to prevent settling). However, if the goals are to fill cavities with insulation and to reduce airflow in and through assemblies, insertion tube installation methods should be accepted and install densities should be established to provide sufficient airflow resistance.

This research sought to evaluate test wall specimens installed to the manufacturer-recommended densities, using the methods identified in the various manufacturers' literature. If the goal is to provide comparable airflow resistance to the benchmarks for historical dense-pack cellulose retrofits (i.e., long-path airflow of $0.33 \mathrm{cfm}_{50} / \mathrm{ft}^{2}$ and short-path airflow of $1.0 \mathrm{cfm}_{50} / \mathrm{ft}^{2}$ ), further testing is necessary to establish recommended install densities for insertion tube installation methods. 


\section{Conclusions and Recommendations}

This report documents airflow resistance test results for dense-pack retrofit applications using MFI materials (i.e., glass fiber and stone wool). The test results are compared to previous airflow resistance tests for dense-pack retrofit applications using 10 different CFI materials.

Loose-fill MFI products (i.e., fiberglass and stone wool) have different fiber structures than CFI and, as a result, mineral fiber products are expected to require different installation densities than cellulose insulation products. However, the recommended installation methods and densities for fiberglass products are unclear. Only one of the five fiberglass materials collected had consistent instructions and recommended install densities between the packaging, dense-pack documentation and weatherization/retrofit documentation. In all other cases, the installer is faced with a range of instructions and install densities to work toward. Greater clarity and consistency are needed in the installation instructions and recommended install densities for fiberglass products used in dense-pack retrofit applications.

Airflow resistance varied significantly between loose-fill fiberglass products, even though all the compared products are marketed and supported for use in dense-pack retrofit applications. When these fiberglass products were installed at approximately $2.2 \mathrm{pcf}$, the variance was $0.33-1.73$ $\mathrm{cfm}_{50} / \mathrm{ft}^{2}$. The distribution of the installed material, and thus the airflow resistance, also depend on installation method. In this testing, BSC sought to qualitatively and quantitatively assess the three installation methods identified in the survey of instructions from packaging and information from dense-pack and weatherization/retrofit documentation: (1) bottom fill, using an insertion tube installed up through a hole at approximately 24 in. above the bottom plate; (2) top fill, using an insertion tube installed down through a hole at approximately $6 \mathrm{in}$. below the top plates; and (3) 2-in. nozzle, installed through two or three holes (e.g., at holes approximately 24 in., 72 in., and 90 in. above the bottom plate).

Two of the three loose-fill fiberglass products tested (installed at approximately $2.3 \mathrm{pcf}$ ) produced long-path flow rates of 0.28 and $0.42 \mathrm{cfm}_{50} / \mathrm{ft}^{2}$ and short-path airflow rates of 0.76 and $1.1 \mathrm{cfm}_{50} / \mathrm{ft}^{2}$. These are comparable to the cellulose dense-pack retrofits benchmarks of 0.33 and $1.0 \mathrm{cfm}_{50} / \mathrm{ft}^{2}$ for the long- and short-path airflow rates, respectively (CFI installed at $3.5 \mathrm{pcf}$ as required by BPI). However, the fiberglass test walls were prepared using the 2 -in. nozzle installation method, not the insertion tube methods recommended as best practice for retrofit applications. These results indicate that there is potential for dense-pack applications of MFI, but that more work needs to be done to develop appropriate standards for real-world installation needs. In particular, further testing should be conducted to establish recommended install densities for insertion tube installation methods.

Finally, none of the stone wool manufacturers support dense-pack retrofit applications using their products. Only one loose-fill stone wool insulation product was collected for testing. The stone wool fibers and nodules were too large to successfully install using either of the insertion tube techniques. Loose-fill stone wool is not recommended for dense-pack retrofit applications. 


\section{References}

BPI (2010). BPI-103 "Standard Test Method for Thermal Insulation Materials Used in Air Retarder Applications.” Malta, NY: Building Performance Institute.

EDU (1986). "Research Shows Increased Building Tightness with Cellulose Insulation.” Energy Design Update, vol. 5, no. 12, December 1986.

Schumacher, C. (2011). Building America Report 1109, High Impact Project - Support of Standards Development: Dense-pack Airflow Resistance, Final Research Report. Somerville, MA: Building Science Corporation. 


\section{Appendix A: Loose-Fill Fiberglass Insulation Products for Dense-} Pack Retrofit Applications

- Certainteed Optima

- Guardian CWI Plus

- Johns Manville Spider

- Knauf EcoFill-WX

- Owens Corning ProPink L77 

Appendix A1.1:
Certainteed Optima
Documentation on Material Packaging 


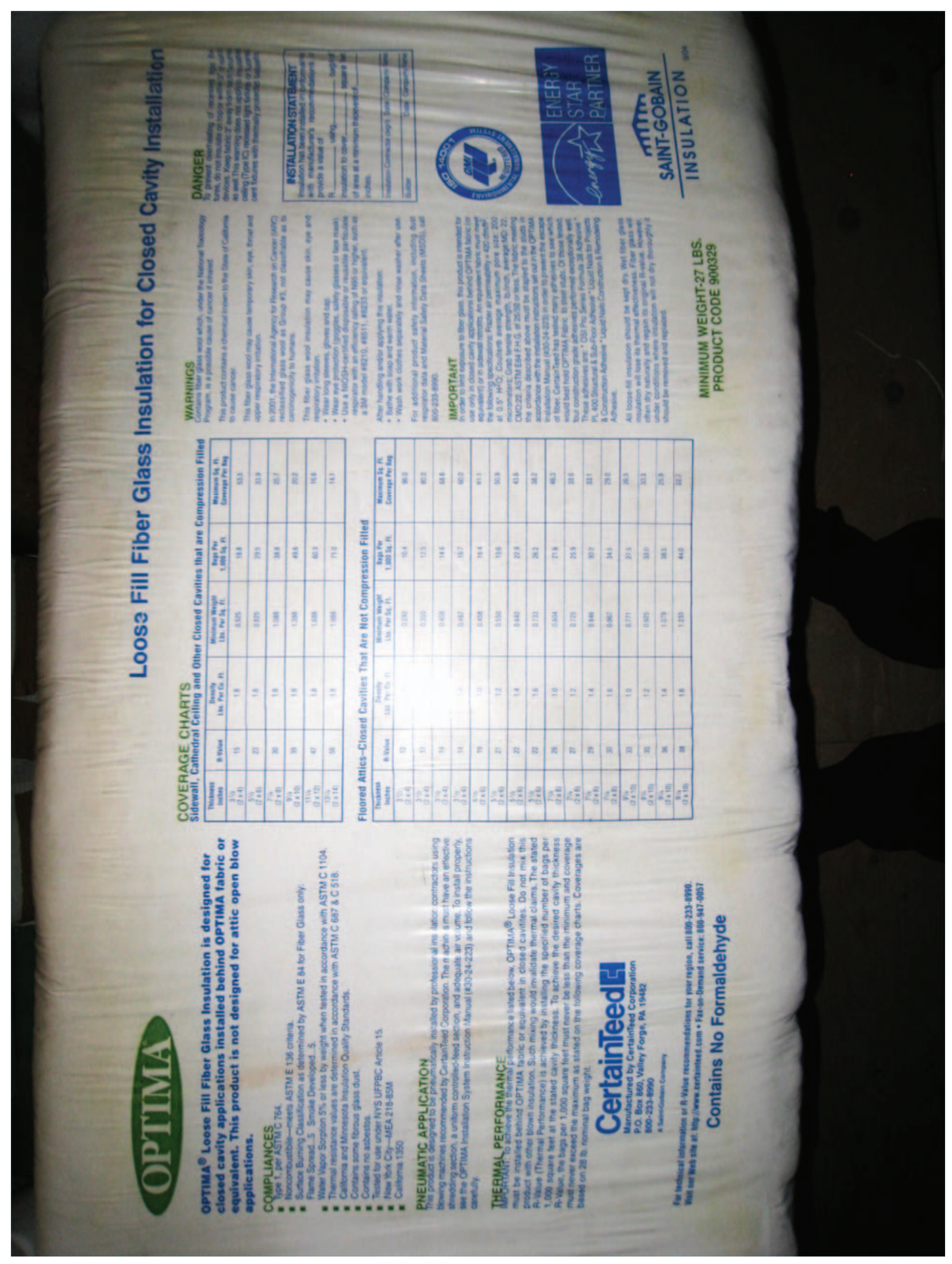




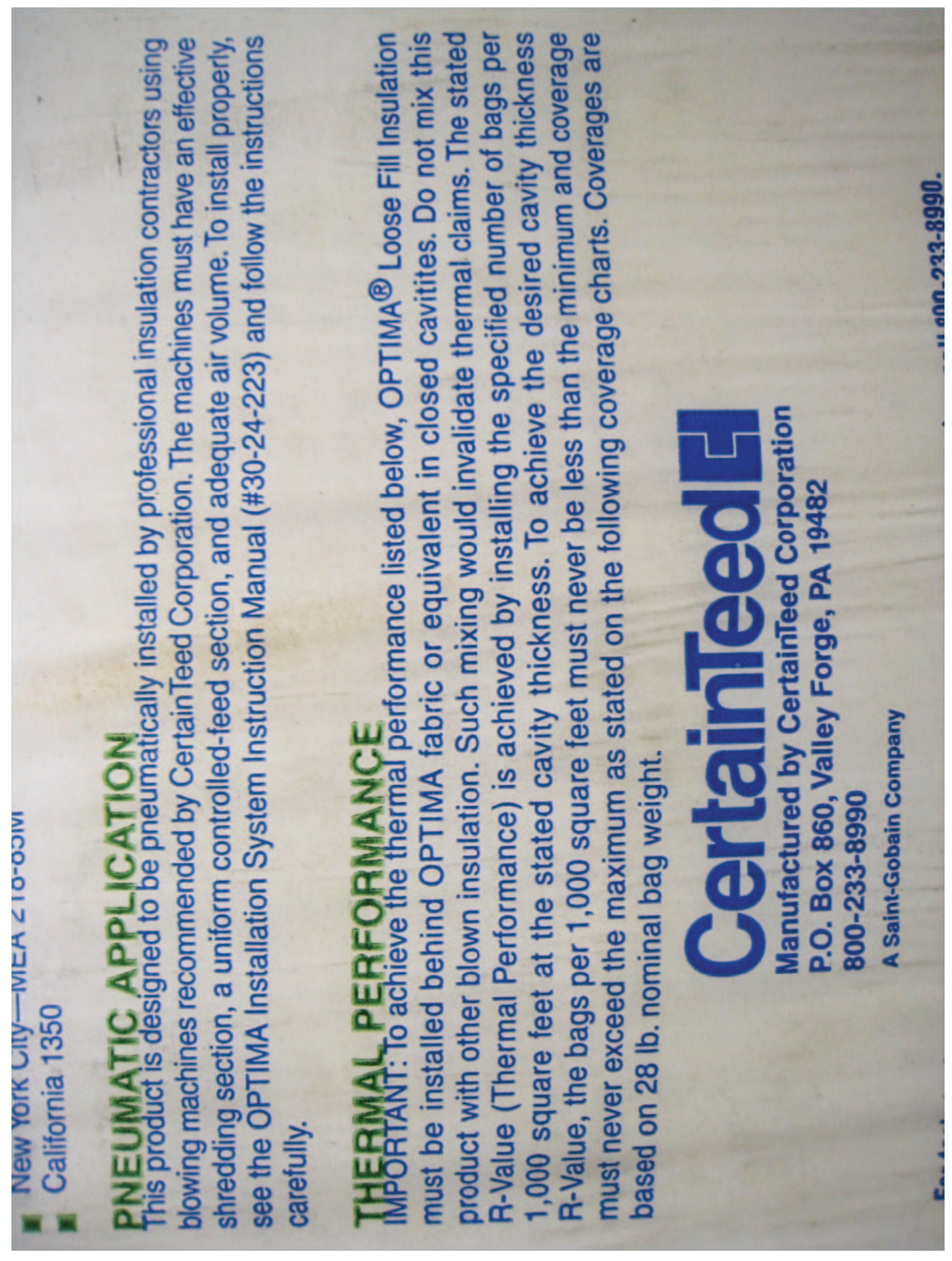




\section{Loosa Fill Fiber Glass Insul}

COVERAGE CHARTS

Sidewall, Cathedral Ceiling and Other Closed Cavities that are Compression Filled

WARNI

\begin{tabular}{|c|c|c|c|c|c|}
\hline $\begin{array}{c}\text { Thickness } \\
\text { Inches }\end{array}$ & R-Vaive & $\begin{array}{c}\text { Density } \\
\text { Los. Per Cu. F. }\end{array}$ & $\begin{array}{c}\text { Minimum Weight } \\
\text { tos. Per Sq. F. }\end{array}$ & $\begin{array}{c}\text { Bags Pet } \\
1,000 \text { Sq. F. }\end{array}$ & $\begin{array}{c}\text { Maximum Sq. F. } \\
\text { Coverage Per Bag }\end{array}$ \\
\hline $\begin{array}{c}31 / 2 \\
(2 \times 4)\end{array}$ & 15 & 1.8 & 0.525 & 18.8 & 53.3 \\
\hline $\begin{array}{c}51 / 2 \\
(2 \times 6)\end{array}$ & 23 & 1.8 & 0.825 & 29.5 & 33.9 \\
\hline $\begin{array}{c}71 / 4 \\
(2 \times 8)\end{array}$ & 30 & 1.8 & 1.088 & 38.8 & 25.7 \\
\hline $\begin{array}{c}91 / 4 \\
(2 \times 10)\end{array}$ & 39 & 1.8 & 1.388 & 49.6 & 20.2 \\
\hline $\begin{array}{c}111 / 4 \\
(2 \times 12)\end{array}$ & 47 & 1.8 & 1.688 & 60.3 & 16.6 \\
\hline $\begin{array}{c}131 / 4 \\
(2 \times 14)\end{array}$ & 56 & 1.8 & 1.988 & 71.0 & 14.1 \\
\hline
\end{tabular}

Contains I

for

ric or

blow

1104.

\section{Floored Attics-Closed Cavities That Are Not Compression Filled}

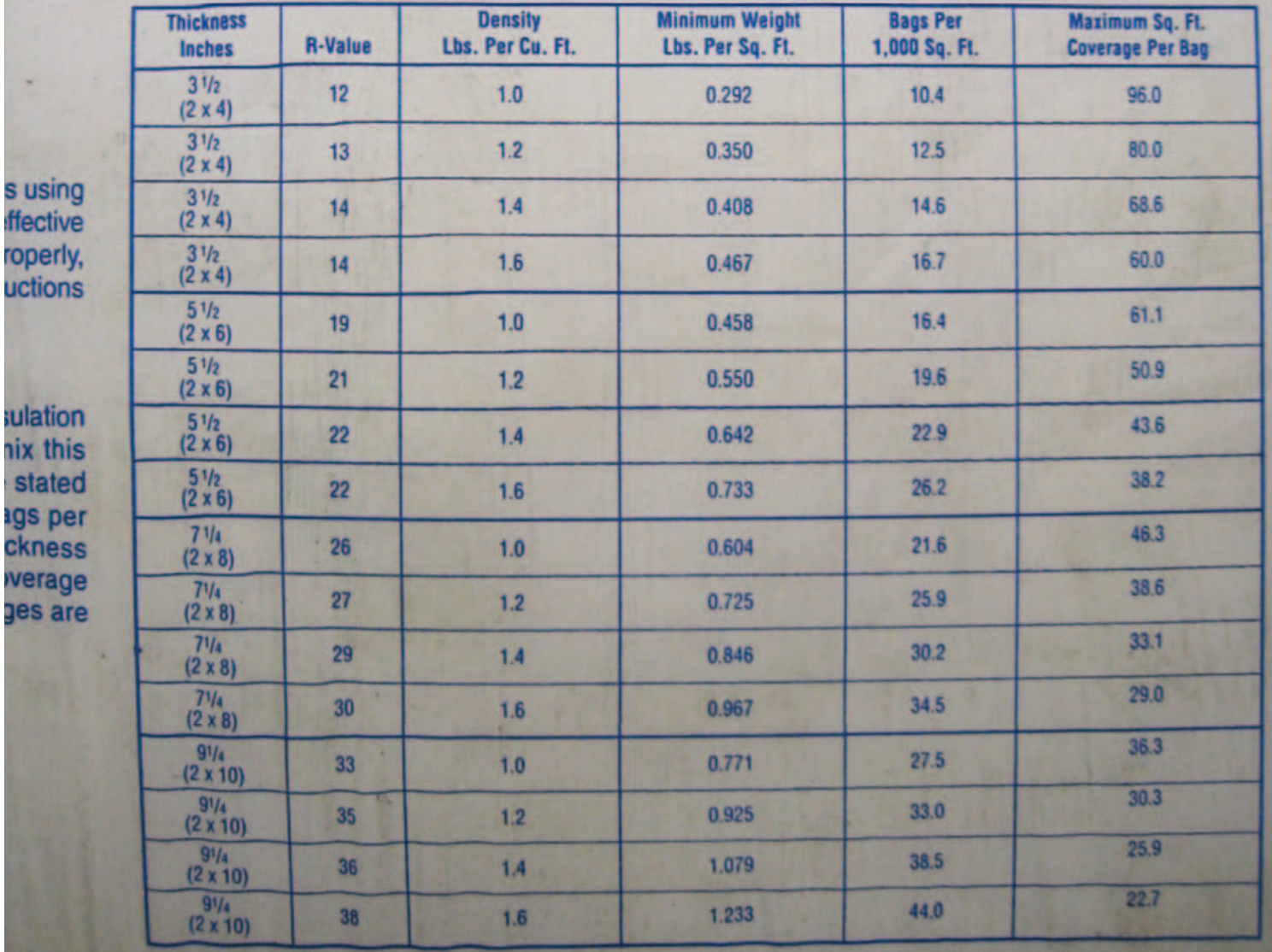

This produc

to cause cr

This fiber $\mathrm{g}$

upper resp

In 2001, the

reclassifie

carcinoger

This fiber

respirator]

- Wear loi

- Wear ey

- Use a I

respirat

a $3 \mathrm{M} \mathrm{m}$

After han

- Bathe v

- Wash r

For addi

respirato

800-233.

IMPO

In order t

use only

equivaler

the follow

at $0.5^{*}$

microme

CMD:22.

the crite

accordan

Installati

of fiber. 1

would be

tour cons

These as

PL 400 S

8 Constr

Adhesiv

All loos

insulatio

often dit

under $c$

should 
Appendix A1.2:
Certainteed Optima
Documentation for Dense-Packing
Sell Sheet, "Certainteed Dense Packing Fiberglass Insulation" 


\section{CertainTeed}

\section{Dense Packing}

\section{Fiber Glass Insulation}

InsulSafe SP OPTIMA

\section{InsulSafe ${ }^{\circledR}$ SP and OPTIMA ${ }^{\circledR}$ offer many}

\section{additional benefits when compared to cellulose}

Historically, cellulose has been promoted as the only choice for dense pack applications. However, CertainTeed InsulSafe SP and OPTIMA loose-fill fiber glass insulation provides the same reductions in air permeance* as cellulose while delivering a number of other significant benefits.

- Fewer packages needed — less labor, handling and jobsite trash

- Higher R-Value per inch — higher wall R-Values

- EPA and BPI approved for weatherization programs and retrofit applications

- GREENGUARD ${ }^{\circledR}$ Children and Schools Certified for indoor air quality

- High recycled glass content - exceeds EPA's Recovered Materials Advisory Notice

-Won't absorb moisture or support mold growth

- Naturally non-combustible; no fire-retardant chemicals added

- Doesn't settle

- Less dust

* BPI-102, "Standard for Air Resistance of Thermal Insulation Used in Retrofit Cavity Applications — Material Specification," is BPl's approved technical standard for insulation used in air sealing, and requires that such products limit maximum air permeance to $3.5 \mathrm{cfm} / \mathrm{ft}^{2}$ (as measured using ASTM C522). InsulSafe SP achieves this permeance rating at a density of $2.2 \mathrm{lbs} / \mathrm{ft}^{3}$ and OPTIMA at $2.5 \mathrm{lbs} / \mathrm{ft}^{3}$. This compares to $3.5 \mathrm{lbs} / \mathrm{tt}^{3}$ for cellulose.

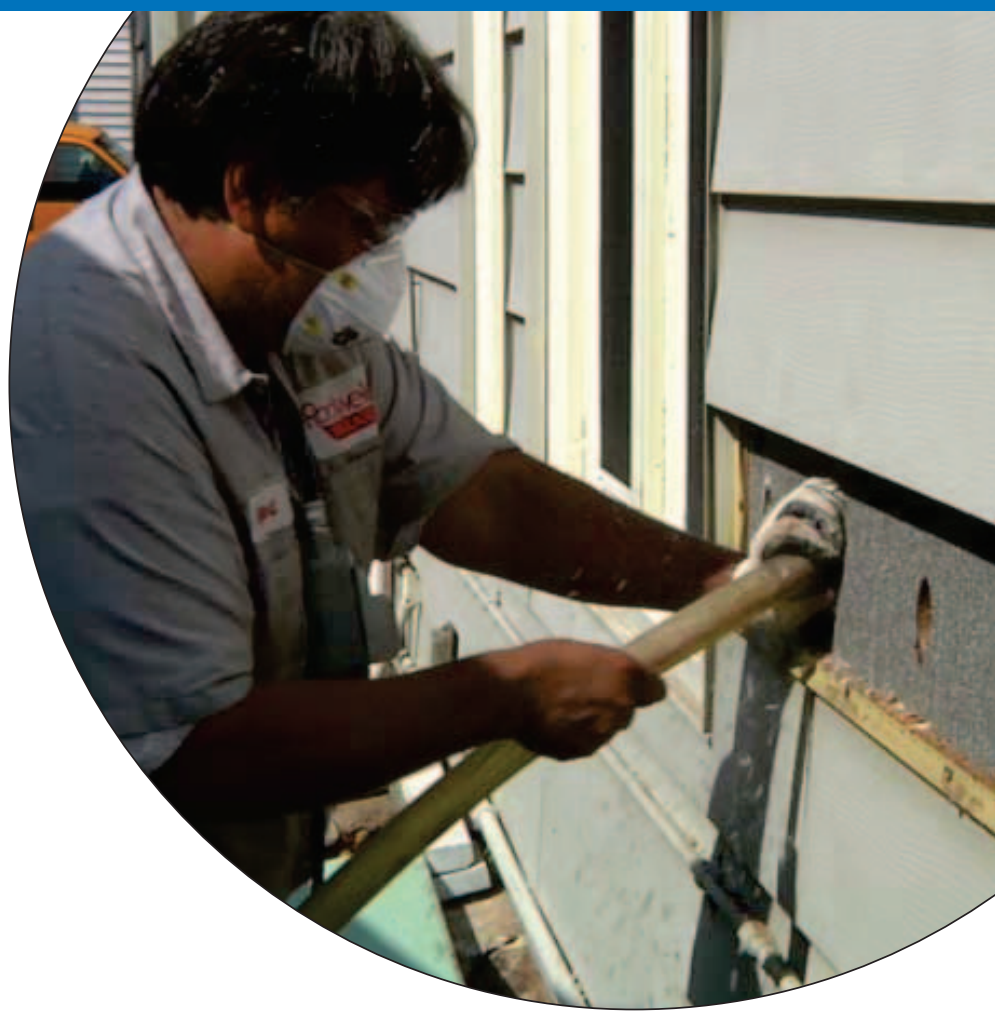

\section{InsulSafe ${ }^{\circledR}$ SP vs. Cellulose}

To insulate a 1,000 sq. $\mathrm{ft}$. attic: 15 packages vs. 46 packages

Fiber Glass: Less waste \& easy to transport

Insulsafe SP

1 package of CertainTeed InsulSafe ${ }^{\circledR}$ SP at R-30 covers $67.1 \mathrm{sq}$. ft.

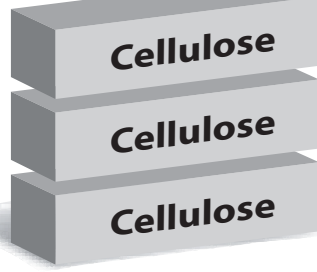

It can take up to 3 packages of cellulose to cover $65.1 \mathrm{sq}$. $\mathrm{ft}$. at R-30

Based on $22 \mathrm{lb}$. package 


\begin{tabular}{|c|c|c|c|c|c|c|c|c|c|c|c|}
\hline \multicolumn{12}{|c|}{ CertainTeed Flber Glass Insulation Dense Pack Coverage Charts } \\
\hline \multicolumn{6}{|c|}{ INSULSAFE ${ }^{\circledR}$ SP } & \multicolumn{6}{|c|}{$\begin{array}{r}\text { OPTIMA }^{\circledR} \\
\end{array}$} \\
\hline Framing & $\begin{array}{l}\text { Cavity } \\
\text { Depth } \\
\text { (inches) }\end{array}$ & R-Value & $\begin{array}{l}\text { Coverage } \\
\text { (max. ft'/pkg.) }\end{array}$ & $\begin{array}{l}\text { Weight } \\
\left.\text { (min. lbs/ } \text { ft't }^{2}\right)\end{array}$ & $\begin{array}{c}\text { Packages } \\
\left(\text { min. } / 1,000 \mathrm{ft}^{2}\right)\end{array}$ & Framing & $\begin{array}{l}\text { Cavity } \\
\text { Depth } \\
\text { (inches) }\end{array}$ & R-Value & $\begin{array}{l}\text { Coverage } \\
\left.\text { (max. } \mathrm{ft}^{2} / \mathrm{pkg} .\right)\end{array}$ & $\begin{array}{l}\text { Weight } \\
\text { (min. lbs/ ft') }\end{array}$ & $\begin{array}{l}\text { Packages } \\
\left(\text { min. } / 1,000 \mathrm{ft}^{2}\right)\end{array}$ \\
\hline $2 \times 4$ & $3 \frac{1}{2}$ & 15 & 48.3 & 0.642 & 20.7 & $2 \times 4$ & $3 \frac{1}{2}$ & 15 & 38.4 & 0.729 & 26.0 \\
\hline $2 \times 4$ & $35 / 8$ & 15 & 46.6 & 0.665 & 21.4 & $2 \times 4$ & $35 / 8$ & 15 & 37.1 & 0.755 & 27.0 \\
\hline $2 \times 4$ & 4 & 17 & 42.3 & 0.733 & 23.7 & $2 \times 4$ & 4 & 17 & 33.6 & 0.833 & 29.8 \\
\hline $2 \times 6$ & $51 / 2$ & 23 & 30.7 & 1.008 & 32.5 & $2 \times 6$ & $5 \frac{1}{2}$ & 23 & 24.4 & 1.146 & 40.9 \\
\hline $2 \times 8$ & $71 / 4$ & 30 & 23.3 & 1.329 & 42.9 & $2 \times 8$ & $71 / 4$ & 30 & 18.5 & 1.510 & 53.9 \\
\hline $2 \times 10$ & $91 / 4$ & 39 & 18.3 & 1.696 & 54.7 & $2 \times 10$ & $91 / 4$ & 39 & 14.5 & 1.927 & 68.8 \\
\hline \multicolumn{6}{|c|}{ Package Net Weight: $31 \mathrm{lbs}$. / Min. Density: $2.2 \mathrm{lbs} / \mathrm{ft}^{3}$} & \multicolumn{6}{|c|}{ Package Net Weight: $28 \mathrm{lbs}$ / / Min. Density: $2.5 \mathrm{lbs} / \mathrm{ft}^{3}$} \\
\hline
\end{tabular}

Blowing Machine: Required — Fiber agitation and conditioning with air pressure control

1. Machine speed - per manufacturer's recommendation

2. Slide gate - start with $1 / 3$ to $1 / 2$ open

3. Air pressure - 2.0 to $2.4 \mathrm{psi}\left(55^{\prime \prime}\right.$ to $66^{\prime \prime}$ of $\left.\mathrm{H}_{2} \mathrm{O}\right)$

(machine back pressure end of insert tube)

4. Transmission (if applicable) - 2nd gear

\section{Blowing Hose:}

1. Internally corrugated hose required (except for wall insert tube)

2. Smooth transition reducers

3. 10 ' cavity insert tube:

a. $1 \frac{1 / 4}{4}$ ID w/ 1/8" wall thickness clear vinyl/plastic tube

b. $1 \frac{1}{2}$ "ID w/ 1/8" wall thickness for larger cavities

( $2 \times 6$ or larger)

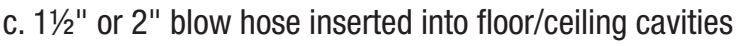
or large sidewall cavities from the attic

\begin{tabular}{|c|c|c|c|c|c|c|c|c|c|}
\hline \multicolumn{10}{|c|}{ Blowing Hose Assembly } \\
\hline $\begin{array}{l}\text { Machine } \\
\text { Outlet Dia. }\end{array}$ & 1st Section & $\begin{array}{c}\text { Reduce } \\
\text { to }\end{array}$ & $\begin{array}{l}\text { 2nd } \\
\text { Section }\end{array}$ & $\begin{array}{l}\text { Reduce } \\
\text { to }\end{array}$ & $\begin{array}{c}\text { 3rd } \\
\text { Section }\end{array}$ & Reduce to & $\begin{array}{l}\text { 4th } \\
\text { Section }\end{array}$ & Reduce to & $\begin{array}{l}\text { 5th } \\
\text { Section }\end{array}$ \\
\hline $4^{\prime \prime}$ & $\begin{array}{l}4^{\prime \prime} \times 0-25 \text { ' then reduce to } 3^{\prime \prime} \\
\text { follow } 3 " \text { machine outlet set up }\end{array}$ & & & & & & & & \\
\hline $3 \frac{1}{11} 2^{\prime \prime}$ & $\begin{array}{l}31 / 2 " \text { x } 0 \text { - } 25^{\prime} \text { then reduce to } 3^{\prime \prime} \\
\text { follow } 3 " \text { machine outlet set up }\end{array}$ & & & & & & & & \\
\hline $3^{\prime \prime}$ & $3^{\prime \prime} \times 50^{\prime} \mathrm{min}$ & $2 \frac{1}{21 "}$ & $2 \frac{1}{2} 2^{\prime \prime} \times 50^{\prime}$ & $2^{\prime \prime}$ & $2^{\prime \prime} \times 50^{\prime}$ & $1 \frac{1}{2 \prime \prime}$ & $1 \frac{1}{2} 2^{\prime \prime} \times 10-25^{\prime}$ & Insert Tube & $10^{\prime}$ \\
\hline $2 \frac{1}{21 "}$ & $2 \frac{1}{2} 2^{\prime \prime} \times 100^{\prime} \min$. & $2^{\prime \prime}$ & $2^{\prime \prime} \times 50^{\prime}$ & $1 \frac{11 / 2 "}{11}$ & $1 \frac{1}{2} 2^{\prime \prime} \times 10-25^{\prime}$ & Insert Tube & $10^{\prime}$ & & \\
\hline
\end{tabular}

\section{Techniques:}

1. Preferred -1 hole $w /$ tube inserted upwards

2. Alternative -1 hole w/ tube inserted downwards or 2 holes with insert tube
NOTE: Please ensure you are in compliance with applicable OSHA and EPA regulations on all job sites.

www.wapcertainsuccess.com
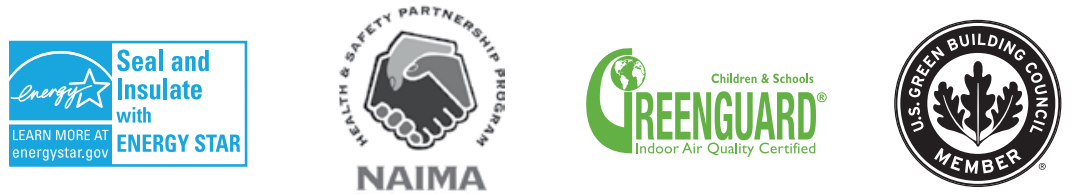

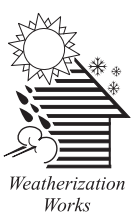

CertainTeed Corporation P.O. Box 860 Valley Forge, PA 19482

Professional: 800-233-8990 Consumer: 800-782-8777

\section{www.certainteed.com/insulation}



Appendix A1.3:
Certainteed Optima

Documentation for Weatherization / Retrofit

Specification Sheet, "Optima Fiber Glass Loose-Fill Insulation for Sidewall Reinsulation" 


\section{Specification Sheet}

\section{CertainTeed}

\section{OPTIMA ${ }^{\oplus}$ Fiber Glass Loose-Fill Insulation for Sidewall Reinsulation}

\section{PRODUCT DESCRIPTION}

Basic Use: OPTIMA ${ }^{\oplus}$ Fiber Glass LooseFill Insulation can be pneumatically installed into existing sidewalls and floored attics. OPTIMA can be used in residential and/or commercial construction as a thermal and acoustical insulation.

Benefits: This product is noncombustible, noncorrosive and odor free. In addition, OPTIMA won't settle, contains no chemicals to cause mildew and fungus growth, contains no formaldehyde, provides no sustenance for vermin, contains no asbestos, won't rot or decay and won't retain moisture.

Composition and Materials: OPTIMA is unbonded, white, virgin fiber glass insulation designed for pneumatic application.

Limitations: The product is designed for use at ambient temperatures in interior (weather protected) locations. Pneumatic equipment must have an effective shredding section, a uniform control feed system and adequate material/air capabilities. Product should be kept dry during shipping, storage and installation. Not to be used for open blow applications.

\section{INSTALLATION}

Installation procedures and techniques must be as recommended by CertainTeed Corporation, using blowing machines approved for fiber glass insulation.

\section{Preparatory Work:}

- Check structural soundness of wall facings. Facings can be damaged by blowing pressure if they are weak or loosely attached.

- Check for symptoms of moisture problems such as blistering paint, mildew, staining, odor, etc., on interior or exterior wall surfaces. Any such problem should be brought to the owner's attention.

- Check for fire stops. If present, they will be at mid-height and holes must be drilled above and below these obstructions.

- Note and mark all areas that must not be drilled (location of wall ducts, vents, recessed cabinets, service panels, etc.).

- Make certain all wall openings through which insulation could enter the house are sealed.

Method(s): Two basic methods are recommended for insulating sidewalls with OPTIMA: the directional nozzle method and the insert tube method.

Method 1 - Directional Nozzle:

- Drill two 11/2" or 13/4" diameter holes into each stud cavity, one hole $3^{\prime}$ up from the base of the wall and one hole $2^{\prime}$ down from the top plates. Don't blow more than $3^{\prime}$ down or $2^{\prime}$ up from any hole.

- Drill holes into cavities below windows and into cavities above windows when there is no solid header.

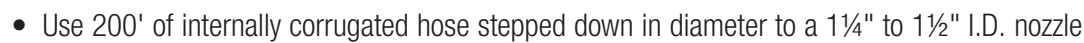
(50' of $3^{\prime \prime}$ to $100^{\prime}$ of $2^{1}{ }^{\prime \prime}$ " to $50^{\prime}$ of $2^{\prime \prime}$ hose). (The nozzle can be fabricated from a metal electrical conduit elbow.)

\begin{tabular}{|c|c|}
\hline Product Name & $\begin{array}{l}\text { OPTIMA }^{\oplus} \text { Fiber Glass } \\
\text { Loose-Fill Insulation }\end{array}$ \\
\hline Manufacturer & CertainTeed Corporation \\
\hline Address & $\begin{array}{l}\text { P.O. Box } 860 \\
\text { Valley Forge, PA 19482-0105 }\end{array}$ \\
\hline Phone & $610-341-7000 \cdot 800-233-8990$ \\
\hline Fax & $610-341-7571$ \\
\hline
\end{tabular}

Website

www.certainteed.com/insulation

\section{TECHNICAL DATA}

Applicable Standards

- Model Building Codes - ICC

- New York City - MEA 218-85M

- NYS UFPBC Article 15

- ASTM C764, Type I

- Material Standards:

- ASTM C764, Mineral Fiber Loose-Fill Thermal Insulation Type 1 - Pneumatic Application Properties:

- Thermal resistance — ASTM C518 and C687

- Critical radiant flux — ASTM E970

- Combustion characteristics - ASTM E136

- Water vapor sorption - ASTM C1104

- Odor emission - ASTM C1304

- Corrosiveness - ASTM C764

- Fungi resistance - ASTM C1338

- GREENGUARD Children \& Schools Certified ${ }^{\mathrm{sm}}$

Fire Resistance

- Surface Burning Characteristics: ASTM E84

- Max. Flame Spread Index: 5

- Max. Smoke Dev. Index: 5

- Noncombustible:

- ASTM E136 / Meets requirements

Thermal / Acoustical Properties

- Thermal Performance:

- Based on $28 \mathrm{lb}$. bag weight, the following thermal performance is achieved, at a design density of 1.6 PCF, at the weights and coverages specified in the table on the other side. To compensate for framing, the net coverage per bag should be increased by $14 \%$ when framing is 16 " 0.C. or $11 \%$ when framing is 24" 0.C. for opaque insulatable wall areas.

- Thermal Resistance:

- In accordance with ASTM C687, the stated R-Values in the table are achieved at weights and coverages specified when insulation is installed with pneumatic equipment in accordance with CertainTeed recommendations.

- Sound Transmission Loss Ratings:

- The same STC ratings obtained with fiber glass blanket insulation can be estimated for OPTIMA. Refer to CertainTeed's Sound Control Brochure (30-29-121).

Quality Assurance

CertainTeed's commitment to quality and environmental management has ensured the registration of the Athens, Chowchilla and Kansas City plants to ISO 9001:2000 and ISO 14001:2004 standards. 


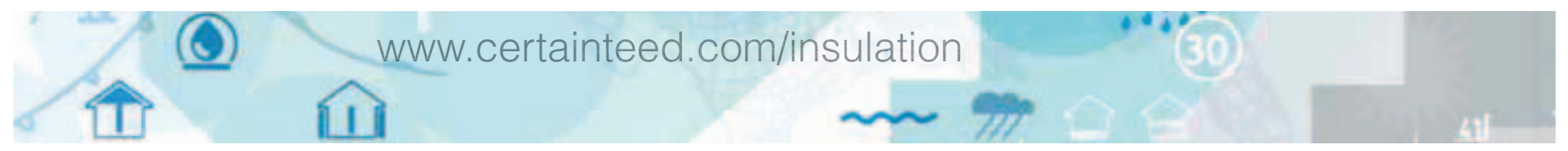

- Insert nozzle in lower hole first and blow downward, filling cavity up to the level of the hole. Insert nozzle in upper hole and blow downward and then upward until the cavity is completely filled.

In both methods, air pressure must be reduced substantially compared to the open blow technique to ensure that no damage is done to the sidewall. The blowing machine should be equipped with an air relief valve.

The actual setting of the equipment will vary depending on the type of hose, equipment limitations and job conditions. When properly filled, wall cavities should have a nominal density of $1.6 \mathrm{lbs}$. per cubic foot.

Method 2 - Insert Tube:

- Drill a single 2" hole in each stud cavity at mid-height.

- Drill holes into cavities below windows and into cavities above windows when there is no solid header.

- Use $200^{\prime}$ of internally corrugated hose $\left(50^{\prime}\right.$ of $3^{\prime \prime}$ to $100^{\prime}$ of $2 \frac{1}{2}{ }^{\prime \prime}$ to $50^{\prime}$ of $2^{\prime \prime}$ hose). The $2^{\prime \prime}$ hose is connected to a reducer and then to a $4^{\prime}$ length of $1 \frac{11}{4}$ to $1 \frac{1}{2}$ " I.D. semi-rigid insert tube.

- Push the insert tube downward through the access hole until the length of tube remaining indicates that the end of the tube is a few inches from the bottom of the cavity.

- Begin blowing OPTIMA, gradually withdrawing the insert tube when an increase in back pressure is felt in the tube. Fill the cavity to the level of the hole.
- Push the insert tube upward through the access hole and continue blowing and withdrawing the tube as above.

Alternate: Drill a single hole approximately 6" below the top plates in each cavity and use an 8 ' length of 11/4" to 11/2" I.D. insert tube.

\section{AVAILABILITY AND COST}

Manufactured and sold throughout the United States. For availability and cost contact CertainTeed in Valley Forge, PA at 800-233-8990.

\section{WARRANTY}

Refer to CertainTeed's Limited Lifetime Insulation Warranty for Blowing Insulation (30-21-1344).

\section{MAINTENANCE}

No maintenance required.

\section{TECHNICAL SERVICES}

Technical assistance can be obtained either from the local CertainTeed sales representative, or by calling CertainTeed Sales Support Group at 800-233-8990.

\begin{tabular}{|c|c|c|c|c|}
\hline R-Value & Bags Per 1000 sq. ft. & Maximum Net Coverage & Minimum Weight/sq. ft. & Minimum Thickness \\
\hline $\begin{array}{l}\text { To obtain a thermal } \\
\text { resistance }(\mathrm{R}) \text { of: }\end{array}$ & $\begin{array}{l}\text { Bags per } 1000 \text { sq. ft. } \\
\text { of net area }\end{array}$ & $\begin{array}{l}\text { Contents of bag should not } \\
\text { cover more than: (sq. ft.) }\end{array}$ & $\begin{array}{l}\text { Weight per sq. ft. of installed } \\
\text { insulation should not be } \\
\text { less than: (lbs.) }\end{array}$ & $\begin{array}{l}\text { Installed insulation } \\
\text { should not be less than: (in.) }\end{array}$ \\
\hline 30 & 34.5 & 29 & 0.967 & $7-1 / 4$ \\
\hline 22 & 26.3 & 38 & 0.733 & $5-1 / 2$ \\
\hline 16 & 18.9 & 53 & 0.533 & 4 \\
\hline 15 & 17.2 & 58 & 0.483 & $3-5 / 8$ \\
\hline 14 & 16.7 & 60 & 0.467 & $3-1 / 2$ \\
\hline
\end{tabular}

For dense packing walls to an air permeance of $3.5 \mathrm{cfm} / \mathrm{ft}^{2}$ at 50 pascals pressure differential, use a minimum density of at least $2.25 \mathrm{pcf}$.

For more information please see our Dense Packing Brochure (30-24-325).
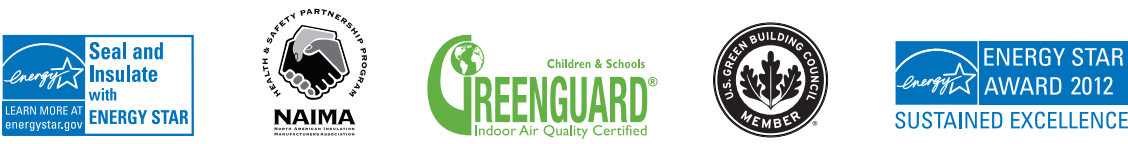

SUSTAINED EXCELLENCE

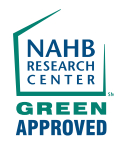

Cert. \#00048

\section{ASK ABOUT ALL OF OUR OTHER CERTAINTEED' PRODUCTS AND SYSTEMS:}

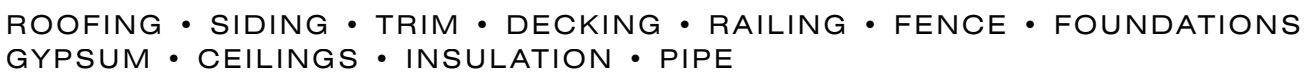

www.certainteed.com/insulation

CertainTeed Corporation

P.O. Box 860

Valley Forge, PA 19482

Professional: 800-233-8990 Consumer: 800-782-8777 


\section{Appendix A2.1: \\ Guardian CWI Plus \\ Documentation on Material Packing}

None available: proper packaging was not available at time of testing; material was provided in generic packaging. 

Appendix A2.2:
Guardian CWI Plus
Documentation for Dense-Packing
"CWI Plus Technical Installation Guide" 


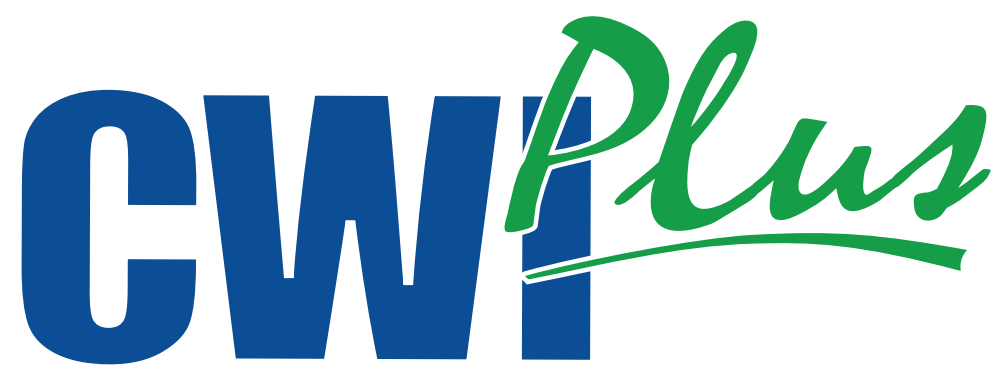

\section{INTRODUCTION}

CWI Plus is a premium fiberglass insulation wall injection system designed primarily for residential retrofit applications. The CWI Plus system utilizes virgin white no formaldehyde added loose-fill fiberglass insulation injected into existing residential studwall cavities that are either empty or partially filled with old insulation.

The CWI Plus system process is very simple: Fill the existing cavities with insulation to help bring the home in line with current residential energy codes. There is no product waste. Energy savings \& total home comfort are benefits of installing CWI Plus.

In addition, your present loose-fill insulation blowing machine can be converted to the CWI Plus system with relative ease at a nominal cost. This conversion is primarily a hose configuration. Your machine can still be used for blowing attics.

This Operating Manual will describe all the aspects of the CWI Plus system, from the process and equipment to installation and troubleshooting. A list of approved CWI Plus insulation blowing machines \& system components is contained in the EQUIPMENT section.

Regarding the use of non-electric machines (machines powered by gas, diesel, or PTO), the use of a mechanical blowing machine is not recommended for this type of retrofit wall insulation project. Appropriate equipment must be designed for fiberglass and have an effective shredding sections, a controlled feed section and sufficient air volume to achieve the desired results. Air blowers with no pressure cut-off can create positive displacement of air. Pressure buildup in the wall cavity may occur causing serious problems.

\section{EQUIPMENT}

The CWI Plus System equipment consists of the following components:

1 ea. Fiberglass insulation blowing machine

1 ea. $\quad 2 "=>1 "$ CWI Plus Reducing Nozzle

$150 \mathrm{ft}$. Ideal spray hose configuration: $3^{\prime \prime}=>2.5^{\prime \prime}=>2^{\prime \prime}$ (50ft of ea.)

1 ea. $\quad 2^{\prime \prime}=>1^{\prime \prime}$ metal or poly reducer

$10 \mathrm{ft} . \quad 1 "$ Flexible wall tubing 


\section{Accessories}

- Poly film, drop cloths, trash bags

- Duct tape

- Brooms or vacuum

- Extension cord - to power insulation machine \& lights

- Hose couplers - to join hose lengths

- Hose reducers - to change hose sizes

- Drill \& bit / hole saw

- Hammer drill \& bit

- Screwdrivers, utility knife, nail pullers, pry bar

- Ladder / Scaffold

- Safety glasses, ear protection, gloves \& dust mask

- Borescope - for observing inside cavities

- Stud Finder Instrument

- Wooden or foam plugs that match the hole saw size

- Patching compounds, adhesives, caulk, texturing materials and putty knives

- Masonry tools

\section{Approved Equipment List}

\section{Insulation Blowing Machine}

\section{Source}

Stewart 1000, 750, 500 \& 350 Series........ Stewart Energy, Ltd.

InsulMaxx 5000, 4000 \& 2000

Force/2 Force/3, Wasp Spray Insulation Components

Krendl 1000, 1300, 2000, 2300 Intec Corp. Krendl Machine Co.

Regarding the use of non-electric machines (machines powered by gas, diesel, or PTO), the use of a mechanical blowing machine is not recommended for this type of retrofit wall insulation project. Appropriate equipment must be designed for fiberglass and have an effective shredding sections, a controlled feed section and sufficient air volume to achieve the desired results. Air blowers with no pressure cut-off can create positive displacement of air. Pressure buildup in the wall cavity may occur causing serious problems.

\section{JOBSITE}

\section{Carefully Survey the Jobsite}

Survey inside and out. This cannot be over-emphasized; shortcuts or complacency in properly surveying the dwelling and the surrounding area can cause serious problems or damage to the residence.

1. Determine if walls are insulated: remove electric cover, dryer vent and / or drill hole in closet.

2. Accurately locate problem obstacles: wiring, plumbing, gas lines, tub enclosures, cold air returns, bulkheads, heat ducts, inset wall heaters \& inset medicine cabinets. These are examples, but not all the items you can encounter in the studwalls. In the stud-chases look for structural support blocking \& existing insulation.

3. Access considerations: under siding, basement floor plates, soffit, attic \& interior.

4. Types of exterior finishes you will encounter: wooden clapboard, vinyl, stucco, brick / stone.

\section{Document}

Create a detailed sketch of the home with locations of all internal utilities and exactly where to drill.

- Determine how to remove siding

- Calculate square footage to be insulated

- Determine material needs

- Identify walls that cannot be insulated, if any

- Calculate time to do entire project

- Calculate plugs required

- Offer interior insulation options to the customer

- Know how to approach all aspects of the project \& time required 
- Price project

- Photograph the project as it progresses \& retain the photos

With all the important surveying of the home that you need to do, in the end, it's a 'blind blow'. That is, you never see the insulation in the wall.

Your best visual survey access here is a Borescope (a camera with a flexible probe) that can give you a glimpse into each stud cavity through the fill holes before insulating. It's a necessary tool for this work.

You must also consider that this process will place you in active contact with the homeowner. Some items to keep in mind:

- Company perception: workers' dress / appearance, truck appearance

- Must arrive on time to the project. May need to be flexible on the time of day this is done.

- Workers able to effectively answer homeowners' questions

- Provide references

- How much disruption is this going to cause the homeowner? Need access inside the home? Where? When? Noise expected?

- Consider a written firm quotation on form or letterhead

- Protect inside of customer's home - if doing an interior fill

- Keep jobsite clean at all times - no fiber blowing around yard

- Never use homeowner's electricity - you will need a generator

- Be sure the homeowner understands what is about to take place \& keep him/her informed at all times throughout the insulating process

- Homeowner must make the project decisions - you determine whether you can abide by them before starting. Come to an agreement on how the project is to proceed.

- Do not over-state benefits / results

\section{SETUP}

This section covers the basic equipment setup, job preparation and application of CWI Plus. For illustration purposes the application is described at $2.2 \mathrm{lb} . /$ cubic foot density.

Setup approved insulation blowing machine according to manufacturer's specifications.

Setup blow hose as indicated below. Next, attach the CWI Plus injection nozzle to the end of the 2 " blow hose. Be sure it is attached securely.

[Ideal spray hose configuration: $3^{\prime \prime}=>2.5^{\prime \prime}=>2^{\prime \prime}=>1$ " metal or poly reducer]

The blowing machine feed gate is set to approximately $75 \%$ of where it would be set for a typical attic job. On the InsulMaxx 4000 \& 5000 machines, use the fiber conditioning card marked 'Reducing Nozzle'.

Hose configuration should be $3^{\prime \prime}=>2 \frac{1}{2} 2^{\prime \prime}=>2^{\prime \prime}$......all in $50 \mathrm{ft}$. increments. A hose arrangement of $100 \mathrm{ft}$. total length is also possible with adequate transition length (10' min.) of each hose diameter listed above.

For tubing walls: Attach tubing, making sure tubing is long enough to reach the top of the wall from the drilled hole.
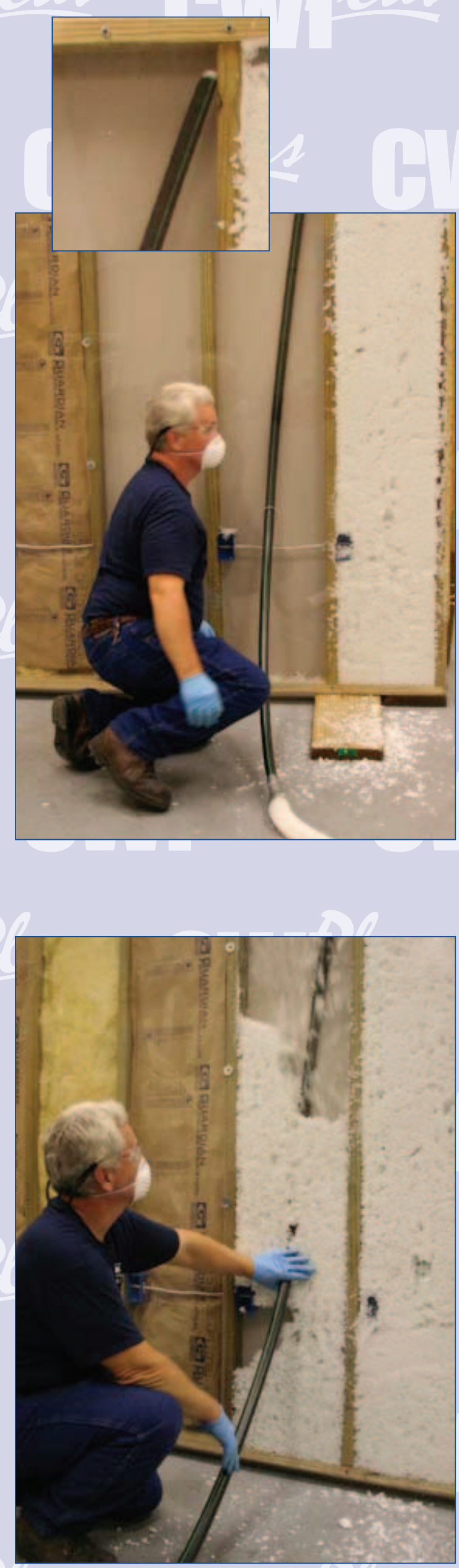


\section{BLOWING / INSTALLATION}

Closed cavity applications can be difficult to judge material usage during installation since fiberglass is compression filled in the cavity.

It is recommended that material usage be monitored as the job progresses, so that the proper number of bags is being installed.

Material feed rate should be approximately 1 bag of CWI Plus every 5 min.

Be sure the fiberglass insulation blowing machine is adjusted to all the recommended settings for operation.

\section{TUBING: (1" ABS Plastic Irrigation Tubing)}

\section{Primary Installation Method}

- Drill a $2.5^{\prime \prime}$ hole $25^{\prime \prime}$ from bottom of wall - typically above most wiring. Use wire to locate next stud. Repeat procedure around house.

- Insert Borescope scope \& observe cavity interior

- Insert tube (1" plastic tubing) through 2.5" opening - pushing tube up to top plate. Mark this distance on the tube with duct tape. Spray paint last 2" of tube to indicate when it's nearly out of the hole.

- Hold tube against the wall to ensure you've reached the top. If you cannot reach the top, you must drill another hole higher up - above the obstruction.

- Insert tube through 2.5" hole - push it to the top - then back the hose out 6". This allows room for the insulation to flow from the hose.

- Turn machine on \& watch material flow

- Filling cavity will take about 60 - 90 seconds

- Remove tube about 8" -10" as material flow slows

- Repeat until cavity is completely full

\section{TUBING - From Top \& Bottom Plates}

\section{Top Plate}

- Drill a $1 \frac{1}{4}$ " hole in the top plate from attic

- Insert the tube down the cavity to the bottom - then retract 8 " - 10"

- Slowly retract tube as cavity fills - until full

\section{Bottom Plate}

- Must have crawl space or basement access

- Drill a $1 \frac{11 / 4}{4}$ hole in the bottom plate

- Insert the tube up the cavity to the top - then retract 8" - 10"

- Slowly retract tube as cavity fills - until full

\section{DRILL \& FILL (Straight Hole)}

- This method will not work if there is some insulation already in the wall

- Use this method only if tubing is not feasible

- Drill minimum 3 equidistant holes per 8-ft. cavity

- Insert Borescope \& observe cavity interior

- Again, watch for wall interior utilities

\section{AFTER INSULATING - PATCHING \& PLUGGING}

- Use foam or wooden plugs to seal all fill holes

- Tap into place with a hammer

- Seal with caulk or patching compound

- Carefully replace siding on exterior applications

- Inspect project: outside, inside, attic \& basement to identify any breaches
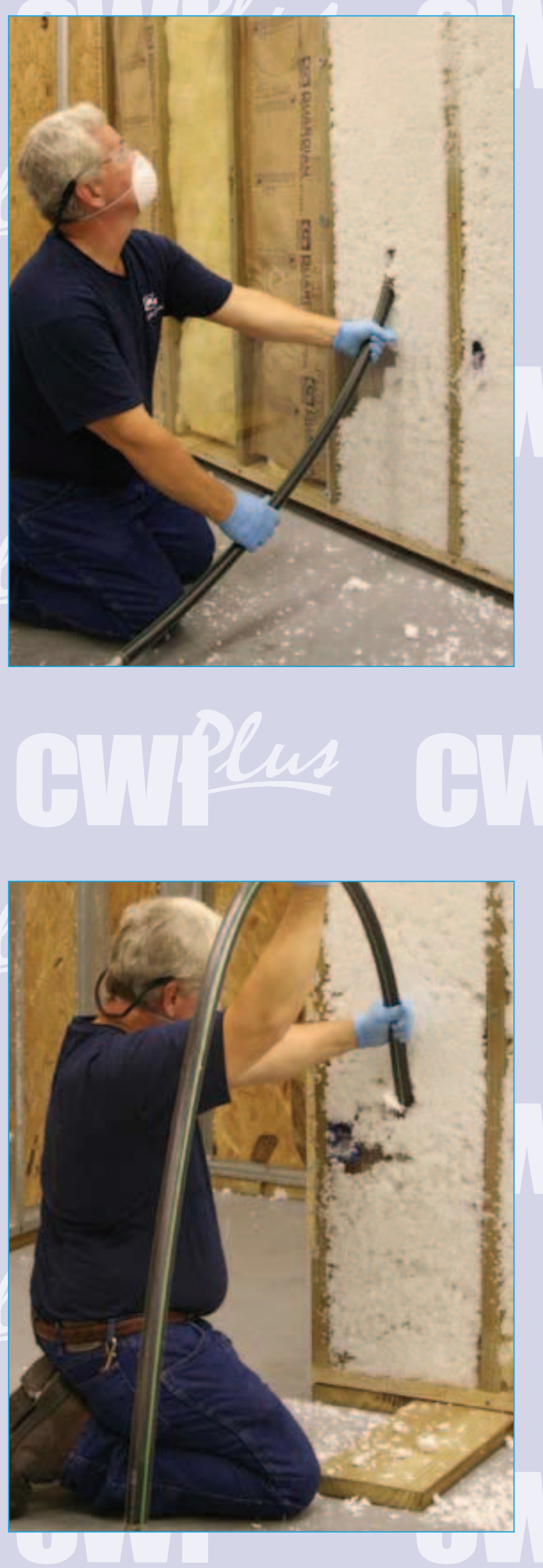


\section{CLEANUP}

This is an important step that is sometimes overlooked or not given proper attention in various types of insulation applications. Proper presentation and complete clean-up gives a professional appearance to the job and focuses the attention of the homeowner on how good the CWI Plus project looks once it's installed. It helps reduce the possibility of a 'call-back'.

Remember: Perception is reality.

- Sweep entire house and properly discard waste.

- Be sure all debris outside the home is gathered-up and disposed of properly. Do not use the homeowner's trash bins.

- Do a final walk-through to ensure the job looks good and is complete and that nothing has been overlooked or left behind.

- Notify the customer that the job is complete.

\section{CWI Plus Product \& System Benefits}

\begin{tabular}{|l|l|}
\hline Product Benefits & System Benefits \\
\hline$\bullet$ Class A fire rating & $\begin{array}{l}\bullet \text { 2-3 times more fiberglass in walls } \\
\text { when compared to standard building } \\
\text { insulation }\end{array}$ \\
\hline$\bullet$ No formaldehyde added & $\bullet$ Improved thermal performance \\
\hline - Excellent coverage per bag & $\bullet$ Excellent sound control properties \\
\hline - Short fiber allows faster install & $\bullet$ Reduced air infiltration \\
\hline - Virtually eliminates gaps and voids & \\
\hline - Non-corrosive & \\
\hline$\bullet$ Pest resistant & \\
\hline
\end{tabular}

CWI Plus complies with ASTM C 764 Type 1 requirements with includes the following test methods:

- ASTM C 518

- ASTM E 136

- ASTM E 84

- ASTM C 1104

- ASTM C 1304

- Sect 12.7

- ASTM C 1338
Thermal Performance Combustion Characteristics Surface Burning, Flame Spread 0, Smoke Developed < 5 Water Vapor Sorption Odor Emission Non-Corrosive Fungi Resistance
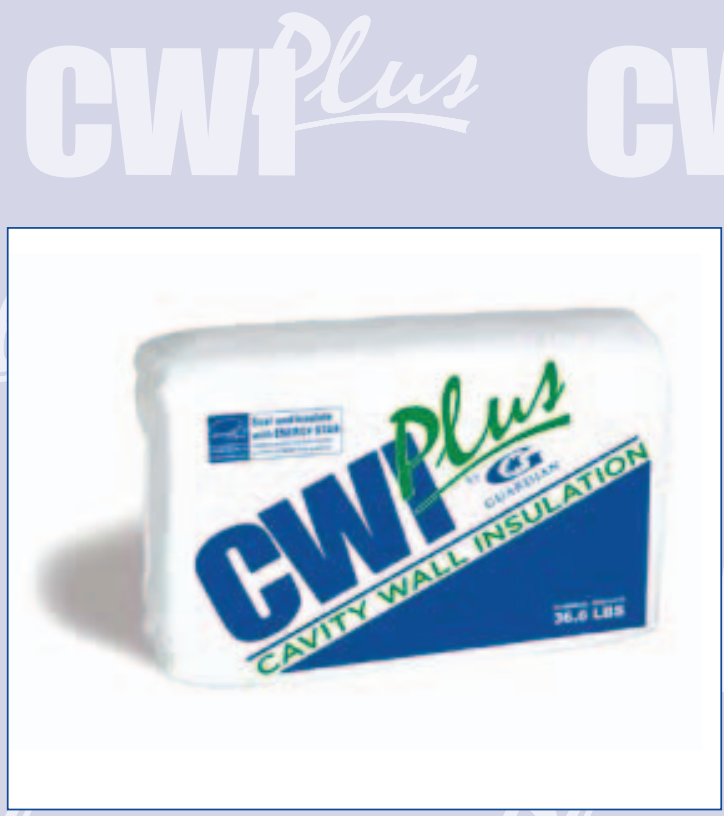


\section{TROUBLESHOOTING}

In this section we try to provide solutions to problems we've encountered in the development process of CWI Plus. We stay product-specific, working to solve difficulties exclusive to the application of CWI Plus. While we cover many aspects of the operation, we assume in this section that the owner and/or operator have knowledge of properly operating, maintaining, and troubleshooting an insulation blowing machine and all its typical components. In addition, we do not address troubleshooting the operation of the insulation equipment or power generator. Those respective equipment manufacturers should be consulted for that information.

\section{Problem: Difficulty installing tube into wall}

Cause: Hole drilled too small

Solution: Drill larger hole.

Cause: Tubing end angle cut incorrectly

Solution: Cut end of tube to approximately $45^{\circ}$ angle

Cause: Tubing kinked or bent as a result catching on wall interior obstructions

Solution: Replace tube \& rotate tube as it is inserted into the wall

\section{Problem: Taking too much time to fill cavity}

Cause: Breach in cavity \& fiber flowing to an unwanted area

Solution: Locate \& repair breach

Cause: Inadequate fiber flow through hose

Solution: Increase product gate opening on machine (in small increments)

Problem: Interior or exterior wall bursts

Cause: Wall inadequately attached

Solution: Re-fasten wall with nails or screws

Cause: Using incorrect insulation machine with a positivedisplacement air blower.

Solution: Use correct machine with an electric blower or backpressure cutoff (Stewart only)

Cause: Incorrect application (drill \& fill nozzle vs. tubing)

Solution: Adjust accordingly

\section{Problem: Continually drilling into interior wall obstacles}

Cause: Drilling pattern

Solution: Adjust drilling pattern (up, down or to the side)

\section{Problem: Material not moving in hose}

Cause: Material plugged at end of tube

Solution: Remove tube \& remove obstruction in tube

Cause: Excess material flow

Solution: Empty hose \& close machine product feed gate

Cause: Air leakage

Solution: Empty hose \& ensure no air is leaking from around all hose connections. (use hose clamps \& duct tape)

Cause: Worn machine airlock seals

Solution: Replace seals 


\section{APPENDIX}

\section{Equipment Vendors}

- Krendl Machine Co. 1201 Spencerville Ave.

Delphos, $\mathrm{OH} 45833$

Ph: 419.692.3060

www.krendlmachine.com

- Intec Corp.

3771 Monarch St.,

P.O. Box 579

Frederick, CO 80530

Ph: 303.466.1611

www.inteccorp.com

- Stewart Energy Group

Brackley Grange

Halse Road

Brackley, Northamptonshire

NN13 6FA United Kingdom

Ph. 011.44.1280.700.550

ian@stewart-energy.com

- Spray Insulation Components

8000 Wilshire Ct. Ste. G

Oklahoma City, OK 73132

Ph. 800.210.1311 / 405.722.9292

www.sprayinsulation.com

Reducing Nozzle: Spray Insulation Components

Copyright@ 2010 Guardian Building Products

This document may not be reproduced either in whole or in part without written permission from Guardian Building Products

\section{Tit GUARDIAN BUILDING PRDDUCTS}

979 Batesville Rd, Greer, SC 29651

$800-569-4262 \cdot 864-297-6101$

www.guardianbp.com 

Appendix A2.3:
Guardian CWI Plus:
Documentation for Weatherization / Retrofit

None found. 
Appendix A3.1:

Johns Manville Spider

Documentation from Material Packaging 


\section{sm/Spicter}

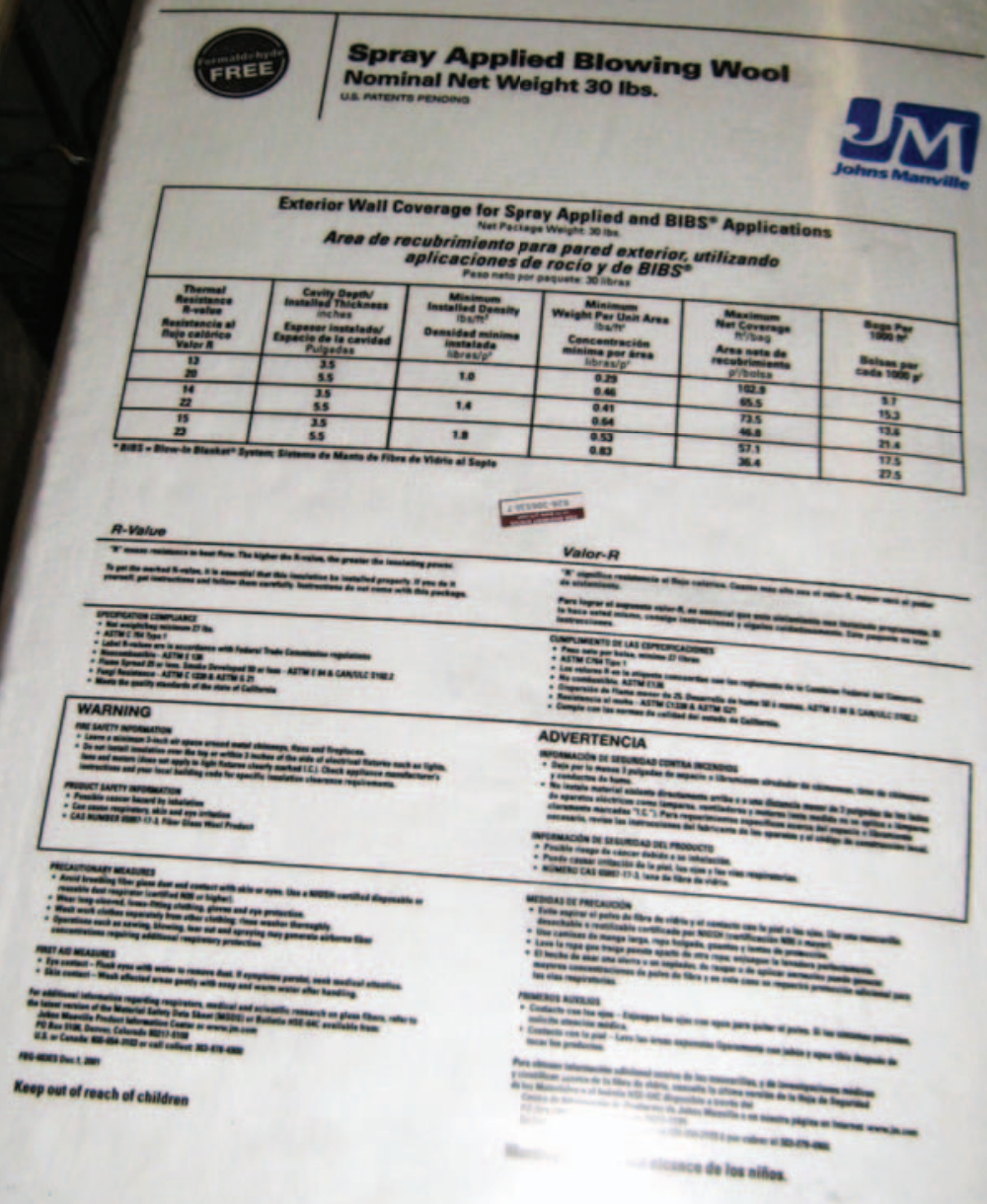

Nominal Net Weight 30 lbs.
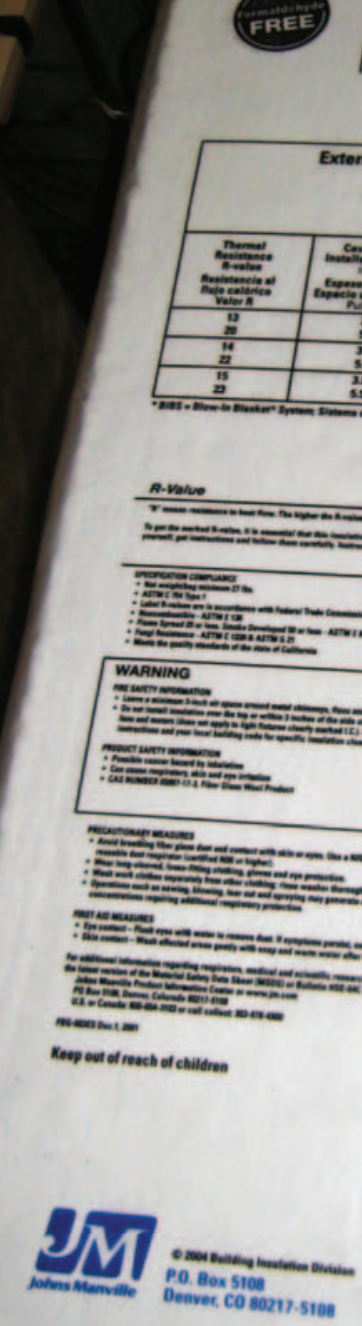

\section{B-7001}

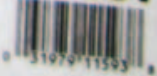

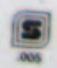




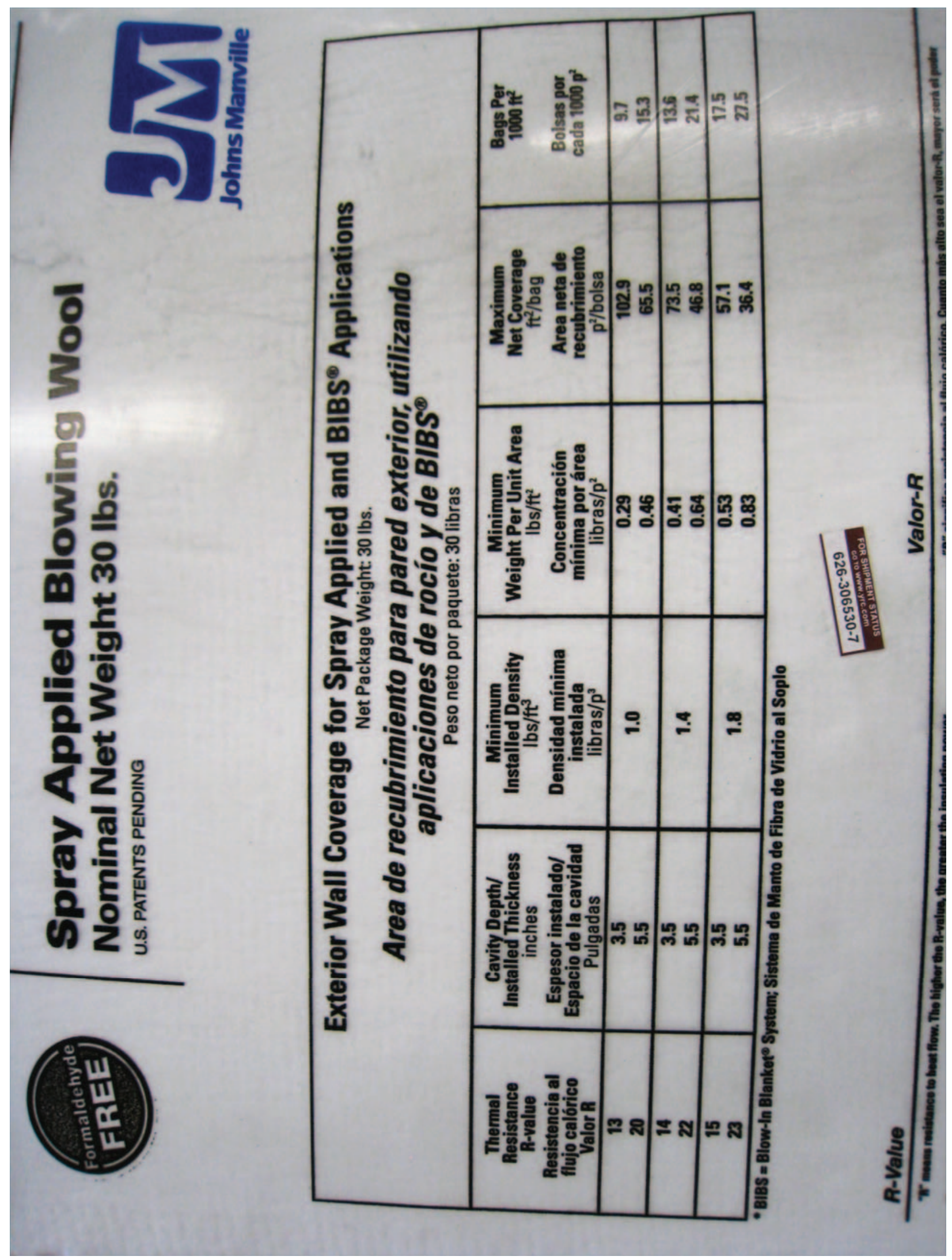


Appendix A3.2a:
Johns Manville Spider
Documentation for Dense-Packing
Sell Sheet, "JM Spider Blown-In Fiber Glass" 


\begin{tabular}{l|c|cc}
\hline Specification Comparison & JM Spider & \multicolumn{2}{c}{ Cellulose } \\
\hline Installed Density, pcf* & 2.2 & 3.5 & 3.7 \\
Bag Weight, lbs & 30 & 30 & 30 \\
Coverage @ 3.5", $\mathrm{ft}^{2} / \mathrm{bag}$ & 47 & 29 & 28 \\
Advertised R-value @ 3.5" & 15 & 13 & 13 \\
Tested R-value @ 3.5" & 15.1 & 12 & 13 \\
Airflow Resistance $\left(\mathrm{lb} / \mathrm{ft}^{2}\right) /\left(\mathrm{ft}^{3} / \mathrm{s}\right)$ & 46 & 22 & 11.9 \\
Air Permeance, $\mathrm{cfm} / \mathrm{ft}^{2} @ 50 \mathrm{~Pa}$ & 2.3 & 4.4 & 26 \\
\hline
\end{tabular}

${ }^{*}$ The recommended installed dense-pack density for JM Spider is 2.2 pcf for drill-and-fill application. Typical installed dense-pack densities for cellulose range from 3.0 to 3.5 pcf; some weatherization agencies recommend 4.0 pcf to improve airflow resistance.

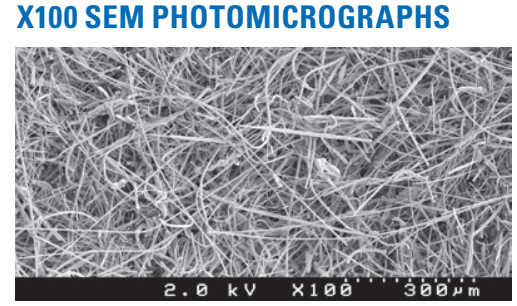

JM Spider Fiber

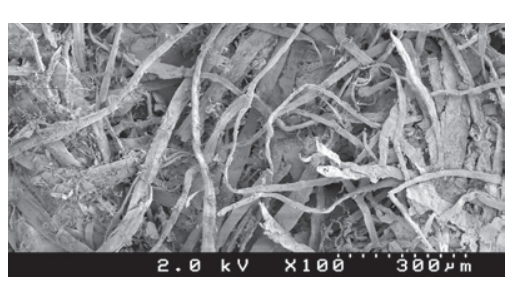

Cellulose Fiber

\section{FINER FIBER = BETTER AIRFLOW RESISTANCE, BETTER THERMAL PERFORMANCE}

Fine-diameter JM Spider fiber creates a tortuous path for heat and airflow, resulting in high thermal and airflow resistance. JM Spider fiber is also very effective at scattering and absorbing IR radiation, which further improves R-value. Coarse-fiber cellulose has more direct airflow passages and poorer IR blocking capability, which results in less resistance to heat and airflow.

ASTM C 522 AIRFLOW RESISTANCE @ 3.5" DENSE-PACK

APPLICATION (50-225 Ipm flow rate per test point)

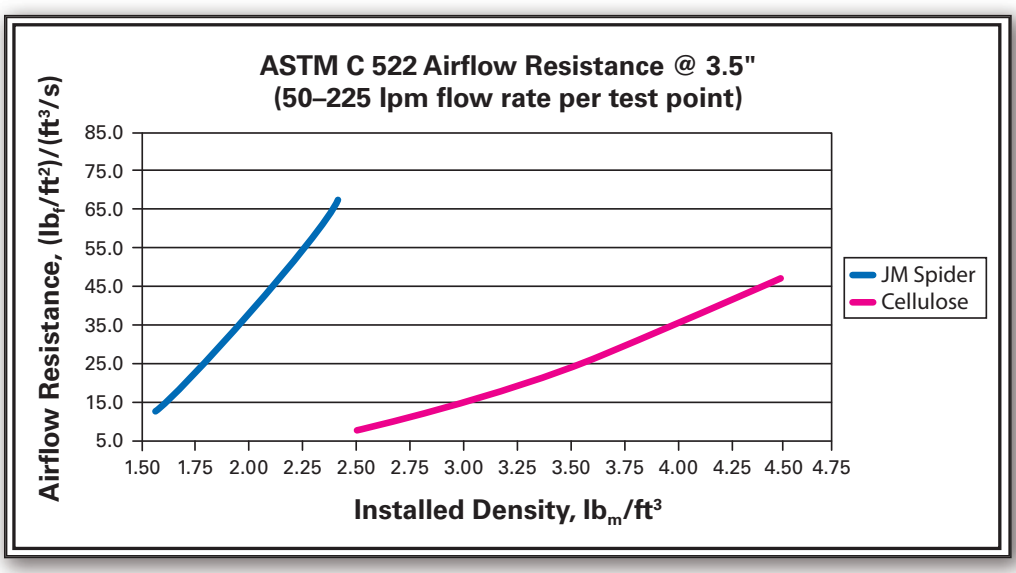

JM Spider has higher airflow resistance than cellulose.
JM SPIDER VS. DENSE-PACK CELLULOSE THERMAL PERFORMANCE (ASTM C518 Testing@ 3.5," 75º mean)

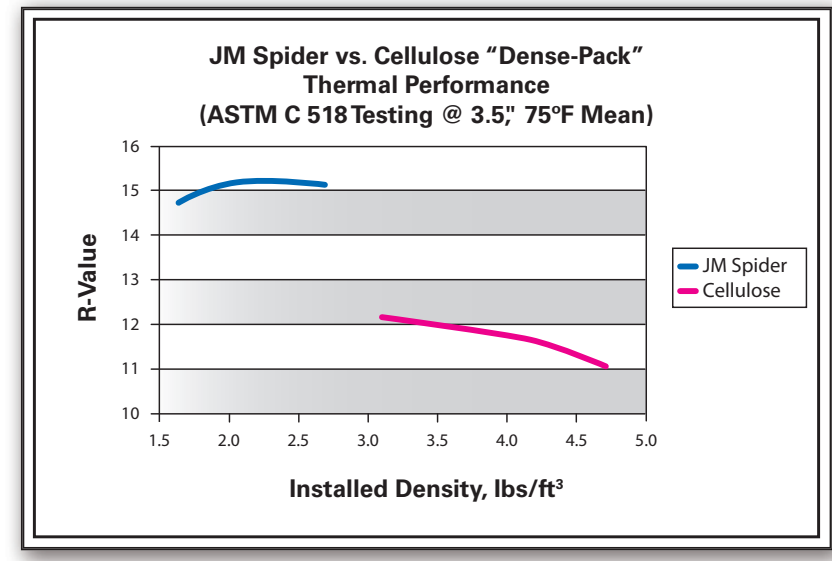

JM Spider provides 4.3 R-value per inch (R-15 @ 3.5").

\section{JM SPIDER FIBER GLASS COMPLIANCE}

ASTM C764, ASTM E84, CAN/ULC S-702, CAN/ULC S-102, ULC S-129, ASTM C1149

HOW TO GET STARTED

Visit specJM.com/retrofit or call (800) 654-3103 to learn more about JM Spider products, applications, training opportunities and additional resources.

Distributed by:

Johns Manville Insulation Systems

717 17th Street (80202)

P.O. Box 5108

Denver, C0 80217-5108

(800) 654-3103

JM.com

BIC-697 04/10 $\quad$ (C) 2010 Johns Manville. Printed in USA 
Appendix A3.2b:
Johns Manville Spider
Documentation for Dense-Packing
Spec Sheet, "Dense Pack JM Spider Insulation for Drill and Fill" 


\section{Dense Pack JM Spider ${ }^{\circledast}$ Insulation}

\section{JM FORMALDEHYDE-FREE ${ }^{\text {TM }}$ FIBER GLASS INSULATION}

JM Formaldehyde-free ${ }^{m}$ fiber glass building insulation offers the thermal and acoustical performance you expect from fiber glass - and it improves indoor air quality because it's made without formaldehyde. Why is that important? Because reducing overall formaldehyde levels in the home creates a healthier living environment, and choosing JM Formaldehyde-free ${ }^{m}$ insulation is one way of achieving that goal. JM offers a complete line of Formaldehyde-free ${ }^{\text {im }}$ fiber glass building insulation. Visit specJM.com or JMhomeowner.com for more information.

\section{PRODUCT DESCRIPTION}

JM Spider insulation offers many big advantages over cellulose in drill-and-fill applications. Incredibly easy to install, it's convenient and saves time, while offering superior thermal and acoustical performance. JM Spider insulation also provides up to 30 percent better airflow resistance than cellulose when installed at recommended densities for site-built construction. Our unique design enables the fibers to more effectively fill tight spaces around pipes, wires and electrical boxes. For example, JM Spider insulation will fill 2x4 cavities up to an impressive R-15 thermal rating and 2x6 cavities up to R-24. In addition, because fiber glass is naturally mold resistant, it does not encourage the growth of mold or mildew.

\section{APPLICATIONS}

Exterior Walls - Drill and fill through:

- Lap wood and shipboard siding

- Wood-based sheet siding (particle board, plywood, etc.)

- Masonry (brick, stone or block)

- Vinyl of other non-wood siding (metal, etc.)

- Stucco

Interior Walls - Drill and fill through:

- Gypsum board

- Plaster/lath

JM Spider insulation also works for weatherization of other exterior cavities such as bonus room floors, cantilevered areas and cathedral ceilings that do not require venting. For these closed cavities, follow the same installation procedures as walls. For open cavities such as floors over crawl spaces, dense pack JM Spider fiber behind netting. (For crawl space floors, be sure to consult the local code requirements for vapor retarders and contact BIBCA if you need information and training on dense packing JM Spider insulation behind netting.) It's also a good idea to install JM Spider insulation in interior walls that contain supply plumbing and PVC waste drains to significantly reduce unwanted noise. Contact your local JM sales representative for availability of JM Spider insulation. Visit specJM.com for additional information, including information on installing.

\section{RECOMMENDED STORAGE AND TRANSPORT}

Store insulation indoors. Keep insulation clean and dry at all times. When transporting, cover completely with a waterproof tarpaulin as necessary.

\section{SPECIFICATION COMPLIANCE}

JM Spider insulation meets ASTM C764, "Standard Specification for Mineral Fiber Loose-Fill Thermal Insulation." JM Spider system meets all building code fire test requirements for concealed and exposed insulation. (See following page for a complete list of test results.)

\section{PACKAGING}

JM Spider fiber glass insulation is available in 30-lb. bags.

\section{SHORT FORM SPECIFICATIONS}

All insulation shown on drawings or specified herein shall be Dense Packed JM Spider ${ }^{\circledR}$ Fiber as manufactured by Johns Manville. Thermal resistance " $\mathrm{R}$ " (RSI) values of the insulation shall be $\mathrm{R}$ (RSI) in ceilings, $\mathrm{R}(\mathrm{RSI})$ in walls and $\mathrm{R}(\mathrm{RSI})$ in floors over unheated spaces.

\section{LIMITATIONS OF USE}

Check applicable building codes.

\section{for Drill and Fill}

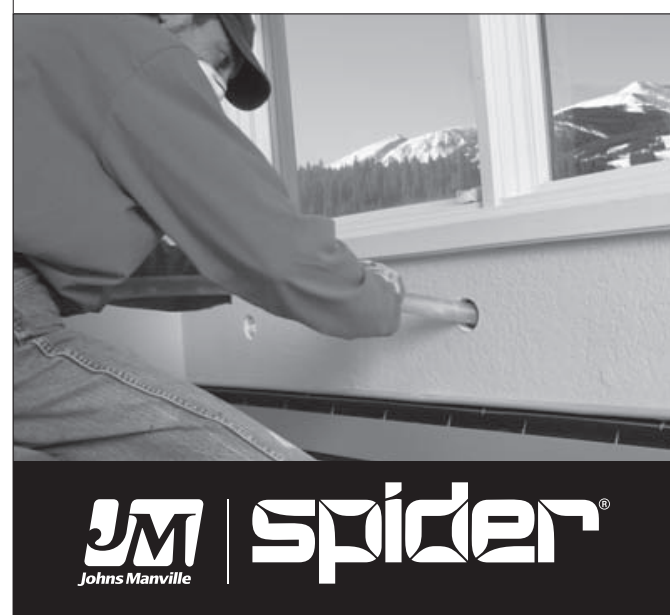

\section{PERFORMANCE ADVANTAGES}

- Improves indoor air quality - because it's made without formaldehyde.

- Energy efficient - provides superior resistance to heat transfer with R-values up to R-15 in a 2x4 cavity.

- Completely fills the cavity and does not settle-the small nodules of fiber glass are resilient and do not deteriorate or lose performance with time.

- Controls sound - reduces transmission of sound through exterior and interior walls and floor/ceiling assemblies. See the JM Spider insulation Acoustical Performance Advantages sheet (BID-0080) for details. - Easy to install - installs at a rate per cavity similar to dense-packed cellulose with significantly less plugging and less dust.

- Mold and mildew resistant - fiber glass is naturally mold resistant.

- Fire resistant and noncombustible

- Noncorrosive - does not accelerate corrosion of pipes, wiring or metal studs.

- Durable - will not rot, mildew or otherwise deteriorate. JM Spider insulation will not hold moisture or permanently lose R-value.

- Small nodule or tuft size allows the product to easily flow around obstacles, such as wiring, and through small-diameter mortar tools.

- Higher installed R-value per inch vs. cellulose (typically more than 20 percent higher $\mathrm{R}$ value up to R-4.3 per inch).

- Works with most types of blowing machines designed to process fiber glass insulation.

- Provides significantly higher airflow resistance than cellulose (per ASTM C522 measurements). 


\section{Dense Pack JM Spider ${ }^{\oplus}$ Insulation}

Visit us at specJM.com for Drill and Fill

Or call: (800) 654-3103

\section{TEST DATA}

\begin{tabular}{l}
\hline Test Method \\
\hline ASTM E84 and CAN/ULC S102.2 \\
Surface Burning \\
ASTM E136 \\
Combustion Characteristics \\
ASTM E970 \\
Critical Radiant Flux \\
ASTM C1338 \\
Fungi Resistance of \\
Insulation Materials \\
ASTM G21 \\
Fungi Resistance of \\
Synthetic Polymeric Materials
\end{tabular}

Results
Flame spread less than 25,
smoke developed less than 50
Pass, indicating noncombustible material
Greater than $0.12 \mathrm{w} / \mathrm{sq} \mathrm{cm}$,
passing for exposed attic installation
Pass, with no growth
Pass, with no growth

\begin{tabular}{l|l}
\hline Test Method & Results \\
\hline ASTM C764 & $\begin{array}{l}\text { No greater than sterile cotton for steel, } \\
\text { copper, aluminum }\end{array}$ \\
ASTrosiveness & See coverage chart for standard R-values
\end{tabular}

\section{Thermal Performance - \\ Heat Flow Meter}

ASTM C1104/C1104M

Water Vapor Sorption

ASTM C1304

Odor Emission

ES Section 01350

VOC Emissions
$5 \%$ or less by weight

No objectionable odor

Pass, with no hazardous emissions

\section{JM SPIDER PREMIUM FIBER GLASS BLOWING WOOL INSULATION NOMINAL 30-LB. BAG COVERAGE CHART FOR CLOSED CAVITY APPLICATION}

\begin{tabular}{|c|c|c|c|c|c|}
\hline Thermal Resistance & $\begin{array}{c}\text { Cavity Depth/ } \\
\text { Insulation Thickness }\end{array}$ & Installed Density & $\begin{array}{c}\text { Minimum Weight } \\
\text { per Area }\end{array}$ & $\begin{array}{c}\text { Number of Bags per } \\
1,000 \mathrm{Sq} . \mathrm{Ft} .\end{array}$ & $\begin{array}{c}\text { Maximum Coverage } \\
\text { per Bag }\end{array}$ \\
\hline R-value & inches & $\mathrm{lbs} / \mathrm{ft}^{3}$ & $\mathrm{lbs} / \mathrm{ft}^{2}$ & bags & $\mathrm{ft}^{2} / \mathrm{bag}$ \\
\hline 15.0 & 3.50 & 2.0 & 0.583 & 19.4 & 51.4 \\
\hline 15.1 & (normal 2x4) & 2.2 & 0.642 & 21.4 & 46.8 \\
\hline 15.2 & & 2.4 & 0.700 & 23.3 & 42.9 \\
\hline 23.6 & 5.50 & 2.0 & 0.917 & 30.6 & 32.7 \\
\hline 23.8 & (normal $2 \times 6$ ) & 2.2 & 1.008 & 33.6 & 29.8 \\
\hline 23.9 & & 2.4 & 1.100 & 36.7 & 27.3 \\
\hline 24.1 & & 2.6 & 1.192 & 39.7 & 25.2 \\
\hline
\end{tabular}

The coverage per bag shown in the above chart is for the unframed area (cavities only) and does not account for the space taken up by wall studs, plates, headers, corners, window framing, etc. Depending on the construction details in a given structure, gross coverage for the overall wood-framed wall area may vary.

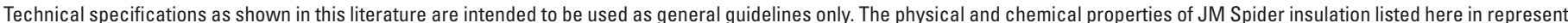

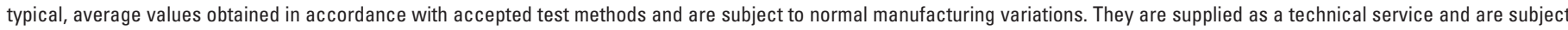

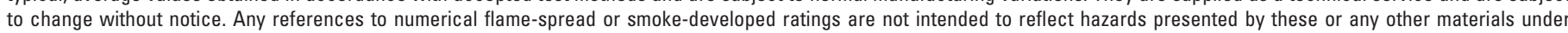

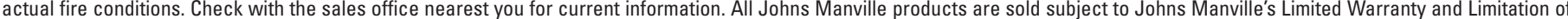

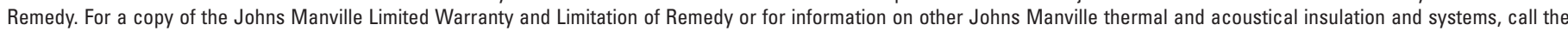
800 number or write to the address, both listed below.
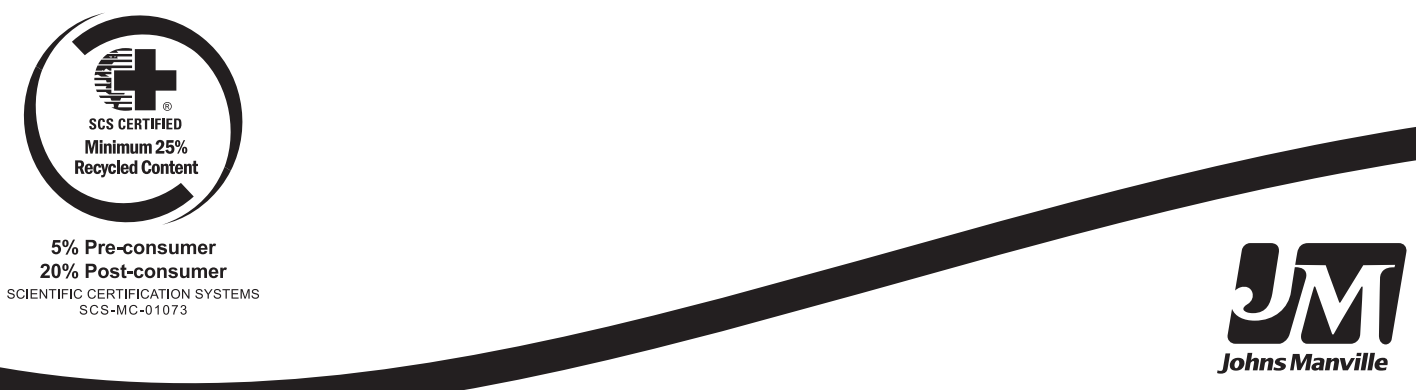

Distributed by:

Johns Manville Insulation Systems

717 17th Street

Denver, CO 80202

(800)-654-3103

specJM.com 
Appendix A3.3:

Johns Manville Spider

Documentation for Weatherization / Retrofit

None Found. 
Appendix A4.1:

Knauf EcoFill Wx

Documentation from Packaging 


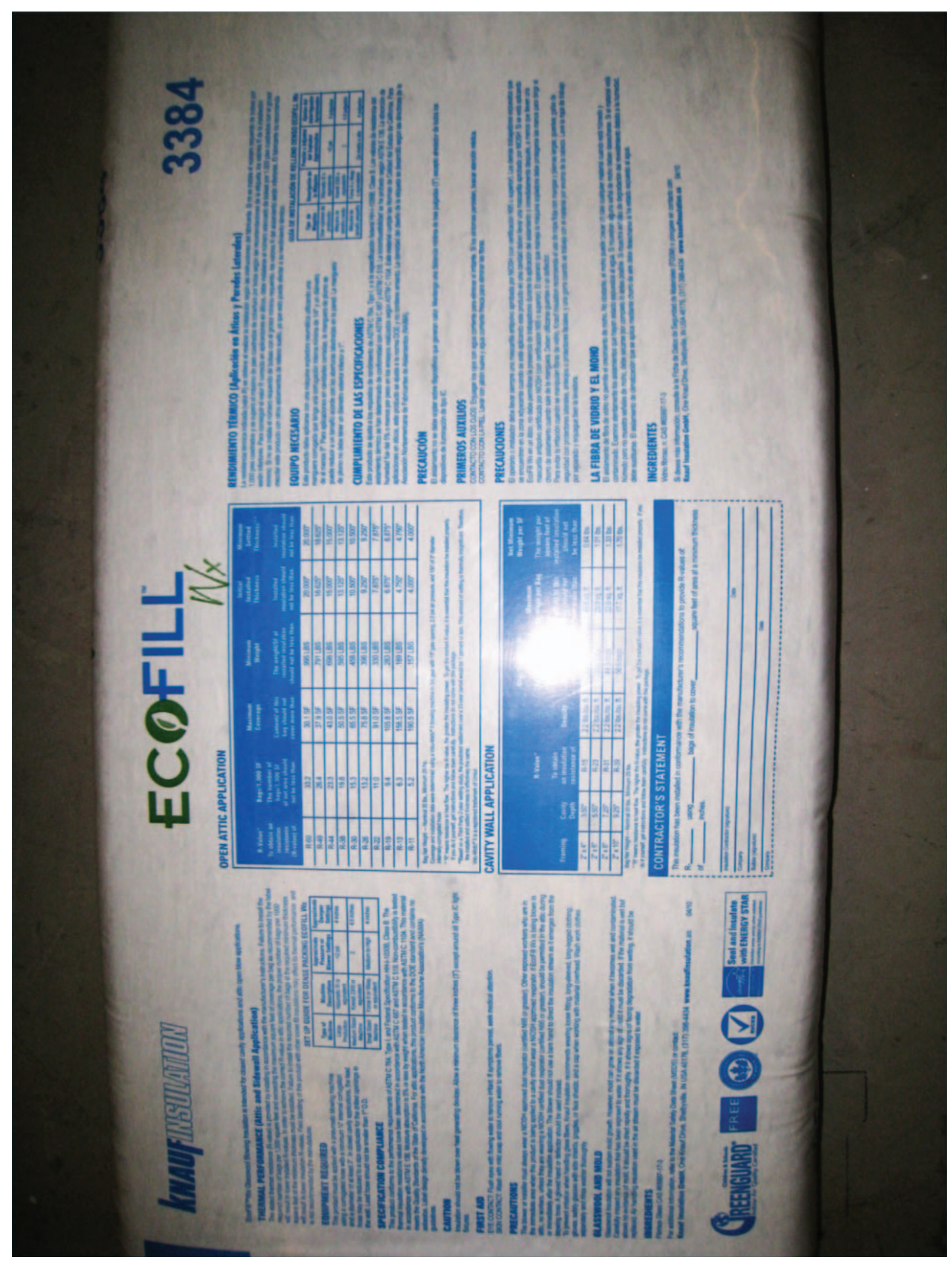


Ecofilm Wx Glasswool Blowing Insulation is intended for closed cavity applications and attic open blow applications.

\section{THERMAL PERFORMANCE (Attic and Sidewall Application)}

The stated thermal resistance ( $R$-value) is provided by installing in accordance with the manufacturer's instructions. Fallure to install the required number of bags per 1,000 square feet and exceeding the maximum square feet of coverage per bag as recommended by the label will result in lower installed R-values. In order to achieve the correct R-value in attic applications, the proper number of bags per 1000 square feet at the minimum thickness must be installed. Failure to install the required number of bags at the required minimum thickness will result in lower insulation R-values. Field blending of this product with other loose fill insulations may affect its thermal performance and is not recommended by the manufacturer.

\section{EQUIPMENT REQUIRED}

This product must be applied with a pneumatic blowing machine yeing a corrugated hose with a minimum $\mathrm{Y}_{4}$ internal comugation and a diameter of al least $3 *$, In closed cevily applications, the lead hose inay be raduced to e size applicalle for the drilled openings in the wall Lead hose should aol be smaller than $1 " 0.0$.

\section{SPECIFICATION COMPLIANCE}

SET UP GUIDE FOR DENSE PACKING ECOFILL WX
\begin{tabular}{|c|c|c|c|}
\hline $\begin{array}{c}\text { Type of } \\
\text { Machine }\end{array}$ & $\begin{array}{c}\text { Machine } \\
\text { Description }\end{array}$ & $\begin{array}{c}\text { Approximate } \\
\text { Pressure or } \\
\text { Blower Settings }\end{array}$ & $\begin{array}{c}\text { Approximate } \\
\text { Damper } \\
\text { Settings }\end{array}$ \\
\hline $\begin{array}{c}\text { Large } \\
\text { Production }\end{array}$ & $\begin{array}{c}\text { Volumatic ill or } \\
\text { equivalent }\end{array}$ & 8 psi & 4 inches \\
\hline $\begin{array}{c}\text { Medium Sized } \\
\text { Machine }\end{array}$ & $\begin{array}{c}\text { Krendl } 2300 \text { or } \\
\text { equivalent }\end{array}$ & 2 & 4.5 inches \\
\hline $\begin{array}{c}\text { Smail Sized } \\
\text { Machine }\end{array}$ & $\begin{array}{c}\text { Force ll or Wasp } \\
\text { or equivalent }\end{array}$ & Medium to High & 4 inches \\
\hline
\end{tabular}

This product conforms to the performance requirements of ASTM C 764, Type I, and Federal Specification HH +1030 B, Class B. The thermal insulation resistance values have been determined in accordance with ASTM C 687 and ASTM C 518. Non-combustibility is tested in accordance with ASTM E 136. Moisture absorption is $5 \%$ or less by weight when tested in accordance with ASTM C 1104. This material meets the Quality Standards of the State of California. For attic applications, this product conforms to the DOE standard and contains no asbestos. Label design density developed in accordance with the North American Insulation Manufacturer Association's (NAIMA) guidelines.

\section{CAUTION}

Insulation should not be blown over heat generating devices. Allow a minimum clearance of three inches (3) except around all Type IC light fixtures.

\section{FIRST AID}

EYE CONTACT: Flush gyes with flowing water to remove irritant. If symptoms persist, seok medical attention.

SKIN CONTACT: Wash with mild soap and cool running water to remove fibers.

\section{PRECAUTIONS}

The blower or installer must always wear a NIOSH approved dust respirator (certified N95 or greater). Other exposed workers who are in the immediate area when this product is being applied to a cavity should wear a NIOSH approved respirator. If EcoFill Wx is being blown in attic, no workers, unless they are wearing a NIOSH certified dust respirator (certified N95 or greater), should be permitted in the attic during or immediately after the insulation application. The blower should not use a bare hand to direct the insulation stream as it emerges from the blowing hose. A gloved hand or deflector should be used instead.

To prevent irritation when handling glass fibers, Knauf Insulation recommends wearing loose fitting, long-sleeved, long-legged clothing; gloves; safety glasses with side shields, goggles, or face shields; and a cap when working with material overhead. Wash work clothes separately and rinse washer thoroughly.

\section{GLASSWOOL AND MOLD}

Glasswool insulation will not sustain mold growth. However, mold can grow on almost any material when it becomes wet and contaminated. Carefully inspect any insulation that has been exposed to water. If it shows any sign of mold it must be discarded. If the material is wet but shows no evidence of mold, it should be dried rapidly and thoroughly. If it shows signs of facing degradation from wetting, it should be replaced. Air handling insulation used in the air stream must be discarded if exposed to water.

\section{INGREDIENTS}

Fibrous Glass CAS $1165997-17-3$

For additional information, refer to the Material Safety Data Sheet (MSDS) or contact:

Knauf Insulation GmbH, One Knauf Drive, Shelbyville, IN USA 46176, (317) 398-4434 www.knaufinsulation.us

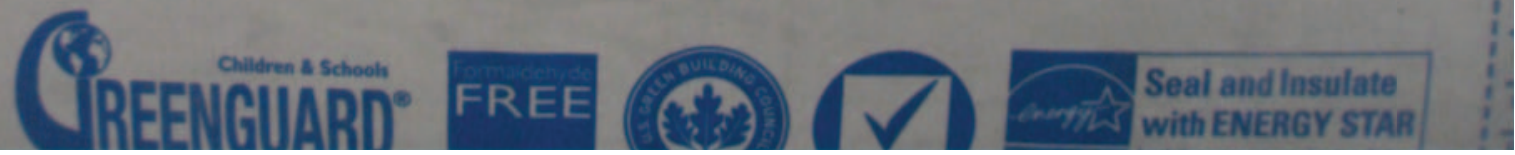




\begin{tabular}{|c|c|c|c|c|c|}
\hline R.Value* & Bags/1,000 SF & $\begin{array}{l}\text { Maximum } \\
\text { Coverage }\end{array}$ & $\begin{array}{l}\text { Minimum } \\
\text { Weight }\end{array}$ & $\begin{array}{l}\text { Initial } \\
\text { Installed } \\
\text { Thickness }\end{array}$ & $\begin{array}{l}\text { Minimum } \\
\text { Settled } \\
\text { Thickness** }\end{array}$ \\
\hline $\begin{array}{l}\text { To obtain an } \\
\text { insulation } \\
\text { resistance } \\
\text { (R-value) of: }\end{array}$ & $\begin{array}{l}\text { The number of } \\
\text { bags } / 1,000 \text { SF } \\
\text { of net area should } \\
\text { not be less than: }\end{array}$ & $\begin{array}{l}\text { Contents of this } \\
\text { bag should not } \\
\text { cover more than: }\end{array}$ & $\begin{array}{l}\text { The weight/SF of } \\
\text { installed insulation } \\
\text { should not be less than: }\end{array}$ & $\begin{array}{l}\text { Installed } \\
\text { insulation should } \\
\text { not be less than: }\end{array}$ & $\begin{array}{l}\text { Installed } \\
\text { insulation should } \\
\text { not be less than }\end{array}$ \\
\hline$R=0$ & 33.2 & $30.1 \mathrm{SF}$ & .995 LBS & $20.000^{\prime \prime}$ & $20.000^{\circ}$ \\
\hline 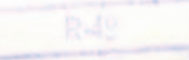 & 26.4 & $37.9 \mathrm{SF}$ & .791 LBS & $16.625^{\prime \prime}$ & $16.625^{\prime \prime}$ \\
\hline $\mathrm{R}-44$ & 23.3 & $43.0 \mathrm{SF}$ & .698 LBS & $15.000^{\prime \prime}$ & $15.000^{\circ}$ \\
\hline R-38 & 19.8 & $50.5 \mathrm{SF}$ & .595 LBS & $13.125^{\prime \prime}$ & $13.125^{\circ}$ \\
\hline R-30 & 15.3 & $65.5 \mathrm{SF}$ & .458 LBS & $10.500^{\prime \prime}$ & $10.500^{\circ}$ \\
\hline R-26 & 13.2 & $75.8 \mathrm{SF}$ & .396 LBS & $9.250^{\circ}$ & $9.250^{\circ}$ \\
\hline R-22 & 11.0 & $91.0 \mathrm{SF}$ & .330 LBS & $7.875^{\circ}$ & $7.875^{\circ}$ \\
\hline$R-19$ & 9.4 & $105.8 \mathrm{SF}$ & 283 LBS & $6.875^{\prime \prime}$ & $6.875^{\circ}$ \\
\hline R-13 & 6.3 & $158.5 \mathrm{SF}$ & .189 LBS & $4.750^{\prime \prime}$ & $4.750^{\circ}$ \\
\hline $\mathrm{R}-11$ & 5.2 & $190.5 \mathrm{SF}$ & .157 LBS & $4.000^{\circ}$ & $4.000^{\circ}$ \\
\hline 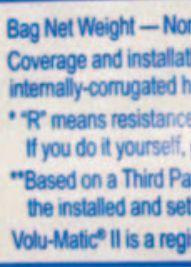 & $\begin{array}{l}\text { al } 30 \text { lbs., Minimum } 29 \text { lbs. } \\
\text { data were determined using a } \\
\text { heat flow. The higher the R-vir } \\
\text { instructions and follow them c } \\
\text { 2-year settling study, the predi } \\
\text { thickness is affectively the sa } \\
\text { ed trademark of Unisul. }\end{array}$ & $\begin{array}{l}\text {-Matic II blowing machine } \\
\text { the greater the insulating } p \\
\text { illy. Instructions do not com } \\
\text { settlement over a } 20 \text {-year } p\end{array}$ & $\begin{array}{l}\text { in } 3 \text { rod gaar with } 13 \text { gata opening, } 2.0 \\
\text { ower. To get the marked R-value, it is } \\
\text { ne with this package. } \\
\text { geriod would be } 1 \text { percent or less. This }\end{array}$ & $\begin{array}{l}\text { psi air pressure, and } 150 \text { of } \\
\text { sessential that this insulation } \\
\text { s amount of setting is therma }\end{array}$ & $\begin{array}{l}\text { of } 3^{\circ} \text { diameter } \\
\text { on be instaled propenty. } \\
\text { nally insignificant. Therefore, }\end{array}$ \\
\hline
\end{tabular}

\section{CAVITY WALL APPLICATION}

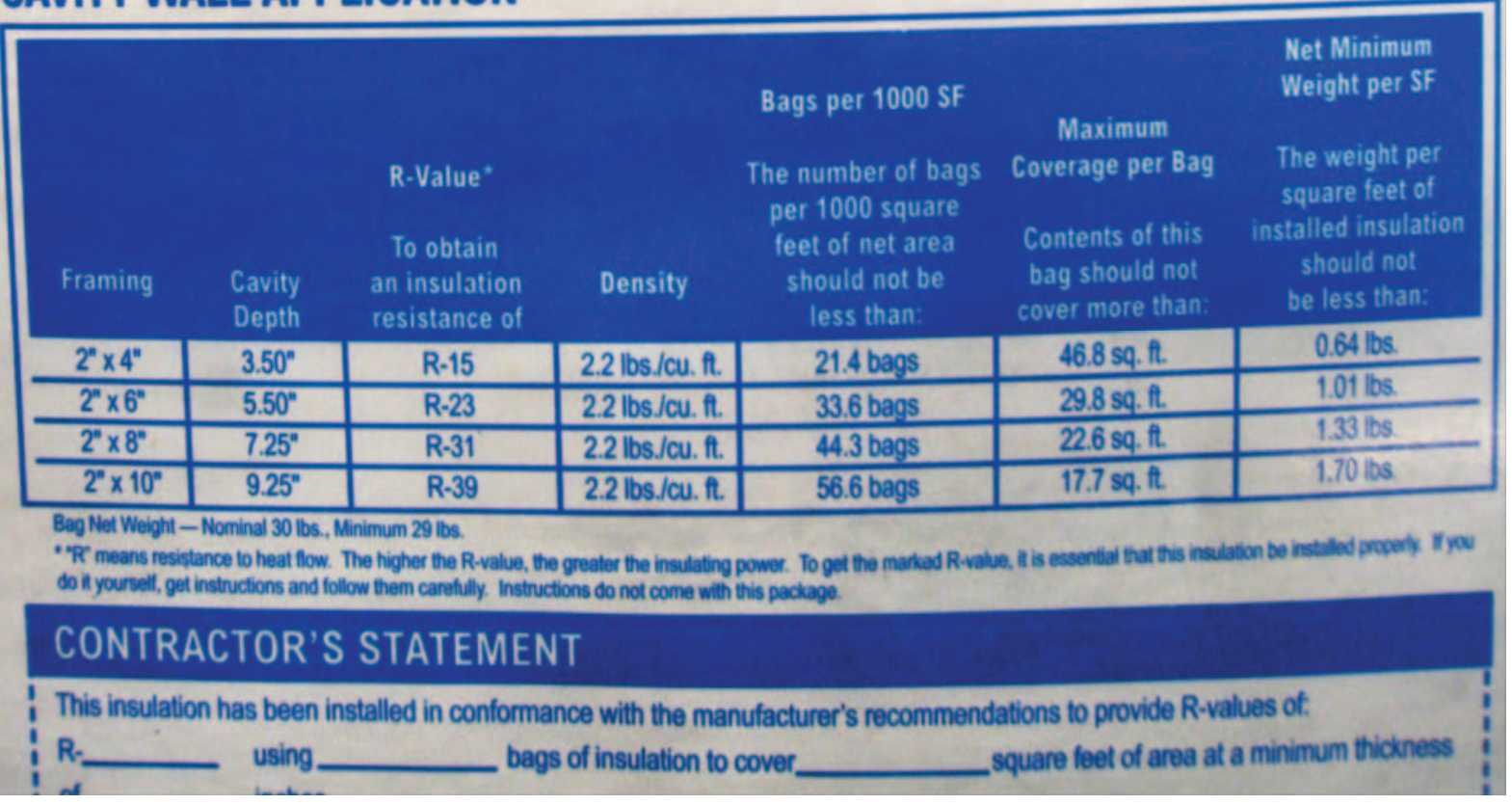




\begin{abstract}
Appendix A4.2:
Knauf EcoFill Wx

Documentation for Dense-Packing
\end{abstract}

Fact Sheet, "Knauf EcoFill Wx Blowing Insulation" 


\section{This is Fiber Glass Blowing Insulation. Read this before you buy.}

\section{What you should know about R-Values.}

The chart shows the R-value of this insulation. "R" means resistance to heat flow. The higher the R-value, the greater the insulating power. Compare insulation $\mathrm{R}$-values before you buy. There are other factors to consider. The amount of insulation you need depends mainly on the climate you live in. Also, your fuel savings from insulation will depend upon the climate, the type and size of your house, the amount of insulation already in your house, and your fuel use patterns and family size. If you buy too much insulation, it will cost you more than what you'll save on fuel. To get the marked R-value, it is essential that this insulation be installed properly.

Sidewall Installation: EcoFill ${ }^{\text {mw }}$ Wx Blow-in-Blanket System has been designed to be dense-packed to a density of 2.2 PCF in sidewalls of existing structures and should be installed by professionals.
Note: The chemical and physical properties of EcoFill" Wx Fiber Glass Blowing Insulation represent average values determined in accordance with accepted test methods. The data is subject to normal manufacturing and testing variations. The data is supplied as a technical service and is subject to change without notice.

Check with your Knauf Insulation sales representative to ensure information is current.

\begin{tabular}{|c|c|c|c|c|c|}
\hline \multicolumn{6}{|c|}{ Open Attic Application } \\
\hline R-Value* & Bags $/ 1,000 \mathrm{SF}$ & $\begin{array}{l}\text { Maximum } \\
\text { Coverage }\end{array}$ & $\begin{array}{c}\text { Minimum } \\
\text { Weight }\end{array}$ & $\begin{array}{c}\text { Initial } \\
\text { Installed } \\
\text { Thickness }\end{array}$ & $\begin{array}{l}\text { Minimum } \\
\text { Settled } \\
\text { Thickness** }\end{array}$ \\
\hline $\begin{array}{l}\text { To obtain an } \\
\text { insulation } \\
\text { resistance } \\
\text { (R-value) of: }\end{array}$ & $\begin{array}{l}\text { The number of } \\
\text { bags } / 1,000 \mathrm{SF} \\
\text { of net area should } \\
\text { not be less than: }\end{array}$ & $\begin{array}{l}\text { Contents of this } \\
\text { bags should } \\
\text { not cover } \\
\text { more than: }\end{array}$ & $\begin{array}{l}\text { The weight/SF } \\
\text { of installed } \\
\text { insulation should } \\
\text { not be less than: }\end{array}$ & $\begin{array}{l}\text { Installed } \\
\text { insulation } \\
\text { should not } \\
\text { be less than: }\end{array}$ & $\begin{array}{l}\text { Installed } \\
\text { insulation } \\
\text { should not } \\
\text { be less than: }\end{array}$ \\
\hline $\mathrm{R}-60$ & 33.2 & $30.1 \mathrm{SF}$ & .995 lbs. & $20.000 "$ & $20.000 "$ \\
\hline $\mathrm{R}-49$ & 26.4 & $37.9 \mathrm{SF}$ & $.791 \mathrm{lbs}$. & $16.625^{\prime \prime}$ & $16.625 "$ \\
\hline R-44 & 23.3 & $43.0 \mathrm{SF}$ & $.698 \mathrm{lbs}$. & $15.000^{\prime \prime}$ & $15.000^{\prime \prime}$ \\
\hline R-38 & 19.8 & $50.5 \mathrm{SF}$ & $.595 \mathrm{lbs}$. & $13.125^{\prime \prime}$ & $13.125^{\prime \prime}$ \\
\hline R-30 & 15.3 & $65.5 \mathrm{SF}$ & $.458 \mathrm{lbs}$. & $10.500 "$ & $10.500 "$ \\
\hline $\mathrm{R}-26$ & 13.2 & $75.8 \mathrm{SF}$ & $.396 \mathrm{lbs}$. & $9.250 "$ & $9.250 "$ \\
\hline $\mathrm{R}-22$ & 11.0 & $91.0 \mathrm{SF}$ & $.330 \mathrm{lbs}$. & $7.875^{\prime \prime}$ & $7.875^{\prime \prime}$ \\
\hline R-19 & 9.4 & 105.8 SF & $.283 \mathrm{lbs}$. & $6.875^{\prime \prime}$ & $6.875^{\prime \prime}$ \\
\hline $\mathrm{R}-13$ & 6.3 & $158.5 \mathrm{SF}$ & $.189 \mathrm{lbs}$. & $4.750^{\prime \prime}$ & $4.750^{\prime \prime}$ \\
\hline $\mathrm{R}-11$ & 5.2 & $190.5 \mathrm{SF}$ & $.157 \mathrm{lbs}$. & $4.000^{\prime \prime}$ & $4.000 "$ \\
\hline
\end{tabular}

Bag Net Weight - Nominal 30 lbs., Minimum 29 lbs.

Coverage and installation data were determined using a Volu-Matic ${ }^{\|}||$blowing machine in $3 r d$ gear with $13^{\prime \prime}$ gate opening, 2.0 psi air pressure, 150' of 3 " diameter internally-corrugated hose.

* "R" means resistance to heat flow. The higher the R-value, the greater the insulating power. To get the marked R-value, it is essential that this insulation be installed properly. If you do it yourself, get instructions and follow them carefully. Instructions do not come with this package.

**Based on a third party 2-year settling study, the predicted settlement over a 20 -year period would be 1 percent or less. This amount of settling is

thermally insignificant. Therefore, the installed and settled thicknesses are effectively the same.

Volu-Matic ${ }^{\oplus}||$ is a registered trademark of Unisul.

\begin{tabular}{|c|c|c|c|c|c|c|}
\hline $\begin{array}{l}\text { Framing } \\
\text { (in inches) }\end{array}$ & $\begin{array}{l}\text { Cavity } \\
\text { Depth } \\
\text { (in inches) }\end{array}$ & $\begin{array}{l}\text { R-Value* } \\
\text { To obtain an } \\
\text { insulation } \\
\text { resistance of: }\end{array}$ & $\begin{array}{l}\text { Density } \\
\text { (cu. ft.) }\end{array}$ & $\begin{array}{l}\text { Bags Per } \\
1000 \text { SF } \\
\text { The number of } \\
\text { bags per } 1000 \\
\text { square feet of net } \\
\text { area should not be } \\
\text { less than: }\end{array}$ & $\begin{array}{c}\text { Maximum } \\
\text { Coverage } \\
\text { Per Bag } \\
\text { Contents of this } \\
\text { bag should not } \\
\text { cover more than: }\end{array}$ & $\begin{array}{l}\text { Net Minimum } \\
\text { Weight per SF } \\
\text { The weight per } \\
\text { square feet of } \\
\text { installed insulation } \\
\text { should not be } \\
\text { less than: }\end{array}$ \\
\hline $2 \times 4$ & 3.50 & R-15 & $2.2 \mathrm{lbs}$. & 21.4 bags & 46.8 sq. ft. & 0.64 lbs. \\
\hline $2 \times 6$ & 5.50 & R-23 & $2.2 \mathrm{lbs}$. & 33.6 bags & 29.8 sq. ft. & $1.01 \mathrm{lbs}$. \\
\hline $2 \times 8$ & 7.25 & R-31 & 2.2 lbs. & 44.3 bags & 22.6 sq. ft. & $1.33 \mathrm{lbs}$. \\
\hline $2 \times 10$ & 9.25 & R-39 & $2.2 \mathrm{lbs}$. & 56.6 bags & 17.7 sq. ft. & $1.70 \mathrm{lbs}$. \\
\hline
\end{tabular}


Appendix A4.3:

Knauf EcoFill Wx

Documentation for Weatherization / Retrofit

Data Sheet, "EcoFill Wx Glasswool Blowing Insulation for Weatherizing Attics and Sidewalls" 


\section{KMAUFINSULATION it's time to save energy}

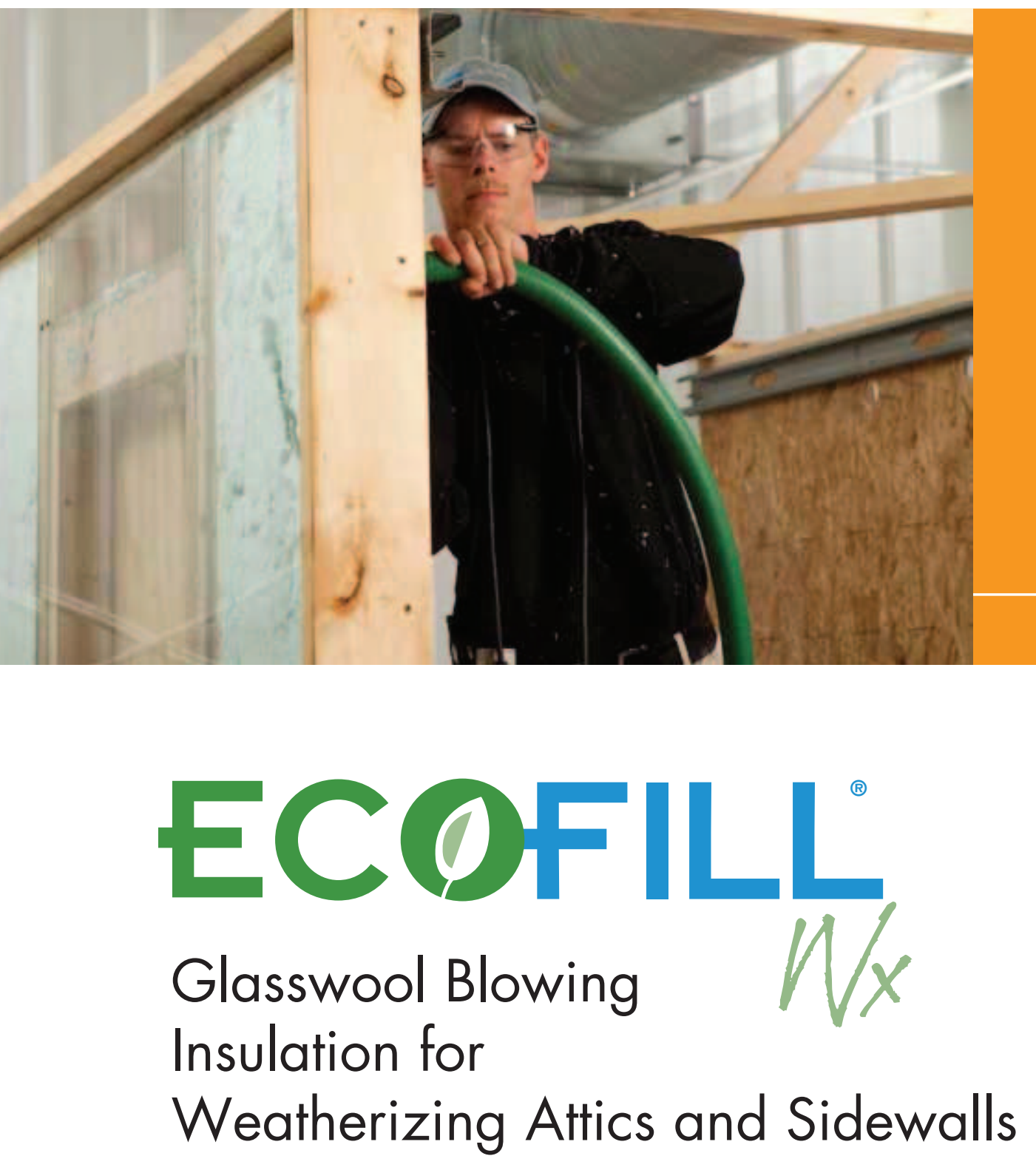




\section{EcoFill ${ }^{\circledR}$ Wx Glasswool Insulation for Weatherizing Attics and Sidewalls}

\section{Description}

Knauf Insulation EcoFill ${ }^{\circledR}$ Wx Glasswool Blowing Insulation is an unbonded, virgin fibrous glass blowing insulation having a high degree of post-consumer recycled content, designed for weatherizing and retrofitting existing housing.

\section{Application}

Knauf Insulation EcoFill Wx Glasswool Blowing Insulation is used to dense-pack sidewalls using the drill and fill technique common in retrofitting homes or in home weatherization activities. EcoFill Wx is also excellent for doing open blows in attics. This means that only one product is needed to complete an insulation retrofit/weatherization project.

\section{Features and Benefits}

Excellent Thermal Properties for Sidewalls:

- Fills all gaps and voids in wall cavities, creating a thermal barrier against outside air and better temperature control.

- Has greater resistance to air infiltration than cellulosic materials.

- Resists heat flow with an R-value of R-15 in $2 \times 4$ construction.

- Resists heat flow with an R-value of R-23 in $2 \times 6$ construction.

- Absolutely will not settle in walls.

\section{And Attics:}

- Will not change from its intended R-value over its lifetime.

\section{Saves Warehouse Space}

- EcoFill Wx requires about one-half of the warehouse space of competing cellulosic products.

- Twice as many jobs can be loaded on a truck when EcoFill Wx is used instead of cellulosic products.
Better Coverage than Cellulose

- More than $2 x$ the coverage per bag

\section{Sustainability}

- $60 \%$ recycled post-consumer glass content and ULE verification every 6 months.

- Each bag contains the equivalent of 30 recycled bottles.

\section{Improves Crew Productivity}

- With EcoFill Wx, installers spend less time handling bags.

- In a 2000 square foot home, about 46 bags of EcoFill Wx are required, compared to 145 bags of cellulosic material.

- Installs cleaner than cellulose, virtually dust-free. Blows clean and smooth and does not require stabilizing.

\section{Strong Poly Bag Packaging}

- EcoFill Wx is packaged in a very strong poly bag that prevents bag breakage and jobsite spillage. The bags stack well and have a coefficient of friction sufficient to reduce slippage.

\section{Indoor Air Quality}

- Certified for indoor air quality as a low emitting product by The GREENGUARD Environmental Institute to both the GREENGUARD Indoor Air Quality Certification Program ${ }^{\mathrm{SM}}$ and the more stringent GREENGUARD Children \& Schools standard and is verified to be formaldehyde free.

\section{Non-combustible}

- Glass fiber is naturally non-combustible and remains so for the life of the product. Unlike cellulose EcoFill Wx requires no additional fire-retardant chemical treatments. Unfaced fiber glass insulation is recognized by building code groups as an acceptable fire stop in residential wood frame walls.

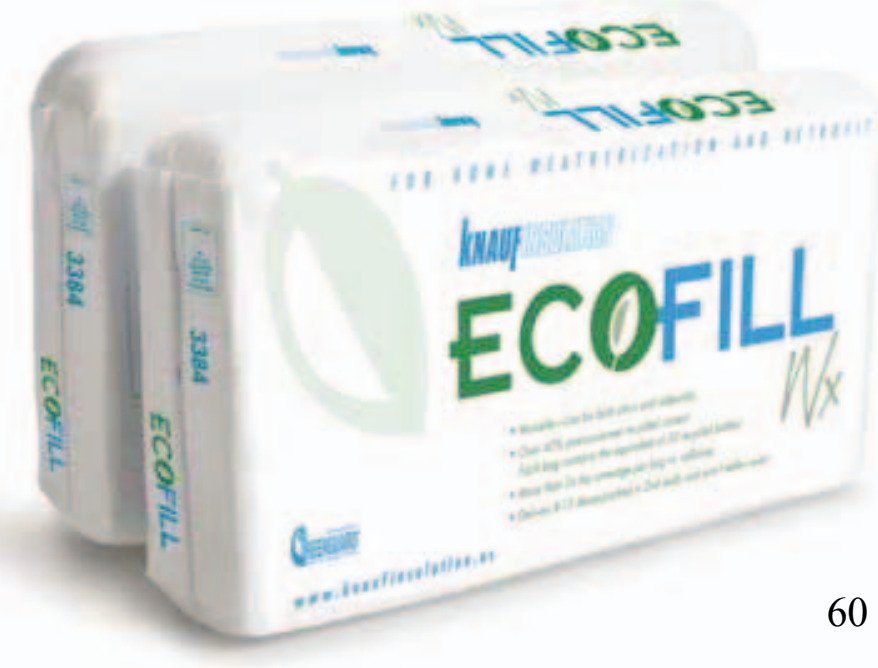

Resists Microbial Growth

- Does not promote the growth of fungi or bacteria.

- Will not rot or sustain vermin, rodents or insects.

Specification Compliance

- ASTM C 764; Type I

- HH-I-1030B; Class B

- GREENGUARD Indoor Air Quality Certified ${ }^{\circledR}$

- GREENGUARD Children and Schools Certified ${ }^{\mathrm{SM}}$

- Knauf Insulation EcoFill Wx Glasswool Blowing Insulation is manufactured with a minimum of $60 \%$ post-consumer recycled glass.

- Meets the Quality Standards of the State of California.

\section{Technical Data}

Air Infiltration Resistance

- When tested against three cellulose products using ASTM C 522, EcoFill Wx showed 20 to $100 \%$ better air flow resistance than three leading brands. (See Table, right)

\section{Noise Reduction}

- Improves Sound Transmission Class (STC) ratings by 4 to 10 points.

- A 3 point STC change is a noticeable improvement.

Surface Burning Characteristics

- Does not exceed 25 Flame Spread, 50 Smoke Developed when tested in accordance with ASTM E 84 and CAN/ULC S102-M88.

\section{Critical Radiant Flux (ASTM E 970)}

- Greater than $0.12 \mathrm{~W} / \mathrm{cm}^{2}$.

Moisture Vapor Sorption (ASTM C 1104)

- $5 \%$ maximum by weight.

\section{Corrosion (ASTM C 764)}

- No greater than sterile cotton.

- Will not accelerate corrosion of aluminum, steel or copper.

\section{Microbial Growth (ASTM C 1338)}

- Does not support microbial growth.

Non-Combustibility (ASTM E 136)

- No temperature rise above $54^{\circ} \mathrm{F}\left(30^{\circ} \mathrm{C}\right)$.

\section{Thermal Performance}

The stated thermal performance of EcoFill Wx Blowing Insulation requires installation in accordance with the manufacturer's instructions. Failure to install the material properly will impact the performance of this product. This product must be installed according to the 


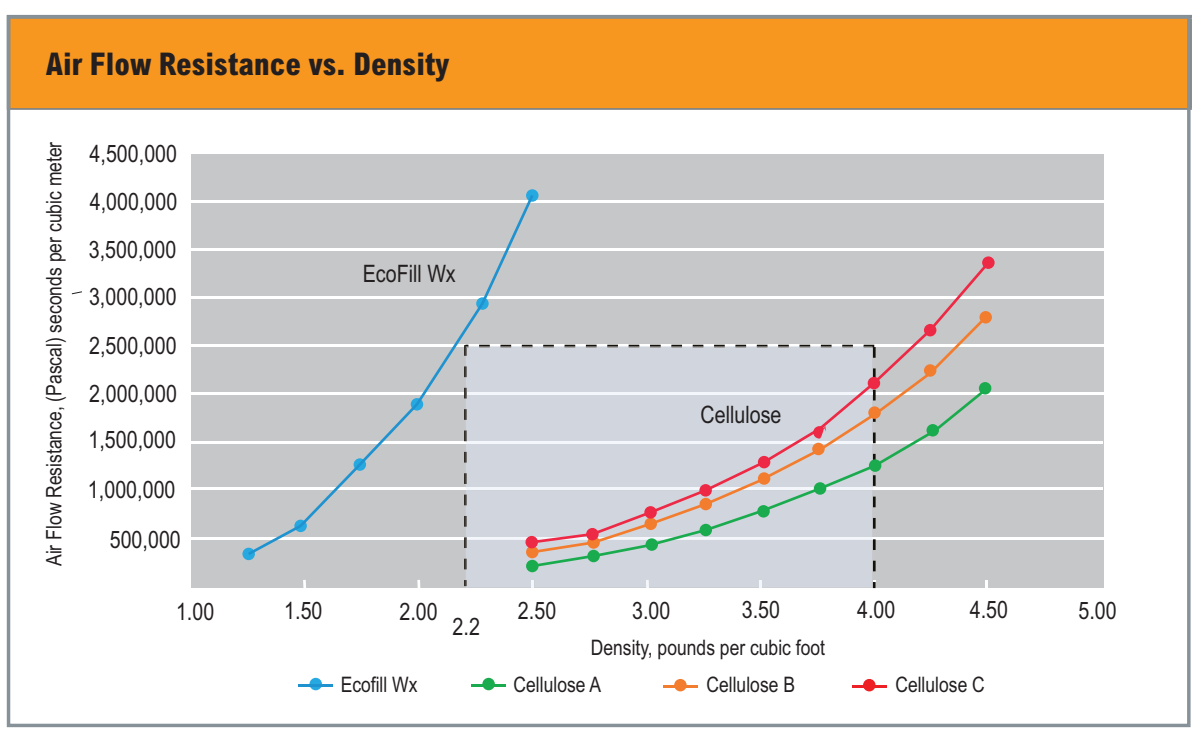

\begin{tabular}{|c|c|c|c|c|c|}
\hline \multicolumn{6}{|c|}{ Open Attic Application } \\
\hline R-Value* & Bags $/ 1,000 \mathrm{SF}$ & $\begin{array}{c}\text { Maximum } \\
\text { Coverage }\end{array}$ & $\underset{\text { Weight }}{\text { Minimum }}$ & $\begin{array}{c}\text { Initial } \\
\text { Installed } \\
\text { Thickness }\end{array}$ & $\begin{array}{l}\text { Minimum } \\
\text { Settled } \\
\text { Thickness** }\end{array}$ \\
\hline $\begin{array}{l}\text { To obtain an } \\
\text { insulation } \\
\text { resistance } \\
\text { (R-value) of: }\end{array}$ & $\begin{array}{l}\text { The number of } \\
\text { bags } / 1,000 \mathrm{SF} \\
\text { of net area should } \\
\text { not be less than: }\end{array}$ & $\begin{array}{l}\text { Contents of this } \\
\text { bags should } \\
\text { not cover } \\
\text { more than: }\end{array}$ & $\begin{array}{l}\text { The weight/SF } \\
\text { of installed } \\
\text { insulation should } \\
\text { not be less than: }\end{array}$ & $\begin{array}{c}\text { Installed } \\
\text { insulation } \\
\text { should not } \\
\text { be less than: }\end{array}$ & $\begin{array}{c}\text { Installed } \\
\text { insulation } \\
\text { should not } \\
\text { be less than: }\end{array}$ \\
\hline R-60 & 33.2 & $30.1 \mathrm{SF}$ & $.995 \mathrm{lbs}$. & $20.000^{\prime \prime}$ & $20.000 "$ \\
\hline R-49 & 26.4 & $37.9 \mathrm{SF}$ & $.791 \mathrm{lbs}$. & $16.625^{\prime \prime}$ & $16.625^{\prime \prime}$ \\
\hline R-44 & 23.3 & $43.0 \mathrm{SF}$ & $.698 \mathrm{lbs}$ & $15.000 "$ & $15.000 "$ \\
\hline R-38 & 19.8 & $50.5 \mathrm{SF}$ & $.595 \mathrm{lbs}$. & $13.125^{\prime \prime}$ & $13.125 "$ \\
\hline R-30 & 15.3 & $65.5 \mathrm{SF}$ & $.458 \mathrm{lbs}$ & $10.500 "$ & $10.500 "$ \\
\hline R-26 & 13.2 & $75.8 \mathrm{SF}$ & .396 lbs. & $9.250 "$ & $9.250^{\prime \prime}$ \\
\hline R-22 & 11.0 & $91.0 \mathrm{SF}$ & $.330 \mathrm{lbs}$. & $7.875^{\prime \prime}$ & $7.875^{\prime \prime}$ \\
\hline R-19 & 9.4 & 105.8 SF & $.283 \mathrm{lbs}$ & $6.875^{\prime \prime}$ & $6.875^{\prime \prime}$ \\
\hline R-13 & 6.3 & $158.5 \mathrm{SF}$ & $.189 \mathrm{lbs}$. & $4.750 "$ & $4.750 "$ \\
\hline R-11 & 5.2 & $190.5 \mathrm{SF}$ & $.157 \mathrm{lbs}$. & $4.000^{\prime \prime}$ & $4.000^{\prime \prime}$ \\
\hline
\end{tabular}

Bag Net Weight - Nominal 30 lbs., Minimum 29 lbs.

Coverage and installation data were determined using a Volu-Matic ${ }^{\circledast}$ || blowing machine in third gear with $13^{\prime \prime}$ gate opening, 2.0 psi air pressure, 150' of $3^{\prime \prime}$ diameter internally-corrugated hose.

* "R" means resistance to heat flow. The higher the R-value, the greater the insulating power. To get the marked R-value, it is essential that this insulation be installed properly. If you do it yourself, get instructions and follow them carefully. Instructions do not come with this package.

${ }^{* *}$ Based on Third Party 2-year settling study, the predicted settlement over a 20-year period would be 1 percent or less. This amount of settling is thermally insignificant. Therefore, the installed and settled thicknesses are effectively the same.

Volu-Matic $^{\otimes}$ II is a registered trademark of Unisul.

\section{See back page for Cavity Wall Applications}

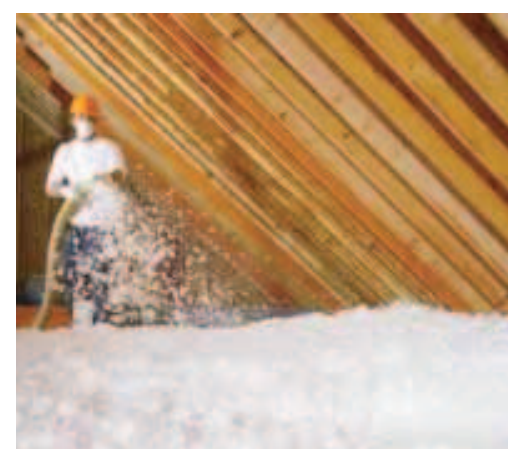

In attic applications, EcoFill Wx blows smooth and fast, providing superior coverage.

coverage charts provided

\section{Equipment Required}

To achieve labeled $R$-value, this product must be applied with a pneumatic blowing machine and a corrugated hose with a minimum $1 / 4$ " internal corrugation, a minimum length of 150'. Coils in the hose should not be less than 36 " in diameter. Acceptable material feed rate is $5-35 \mathrm{lbs}$./minute. The recommended feed rate is $15-35 \mathrm{lbs}$./minute.

\section{Glasswool and Mold}

Glasswool insulation will not sustain mold growth. However, mold can grow on almost any material when it becomes wet and contaminated. Carefully inspect any insulation that has been exposed to water. If it shows any sign of mold it must be discarded. If the material is wet but shows no evidence of mold, it should be dried rapidly and thoroughly.

\section{Notes}

The chemical and physical properties of Knauf Insulation EcoFill Wx Blowing Insulation represent typical average values determined in accordance with accepted test methods. The data is subject to normal manufacturing variations. The data is supplied as a technical service and is subject to change without notice. References to numerical flame spread ratings are not intended to reflect hazards presented by these or any other materials under actual fire conditions.

Check with your Knauf Insulation sales representative to assure information is current. 


\section{KMAUFWISULATION it's time to save energy}

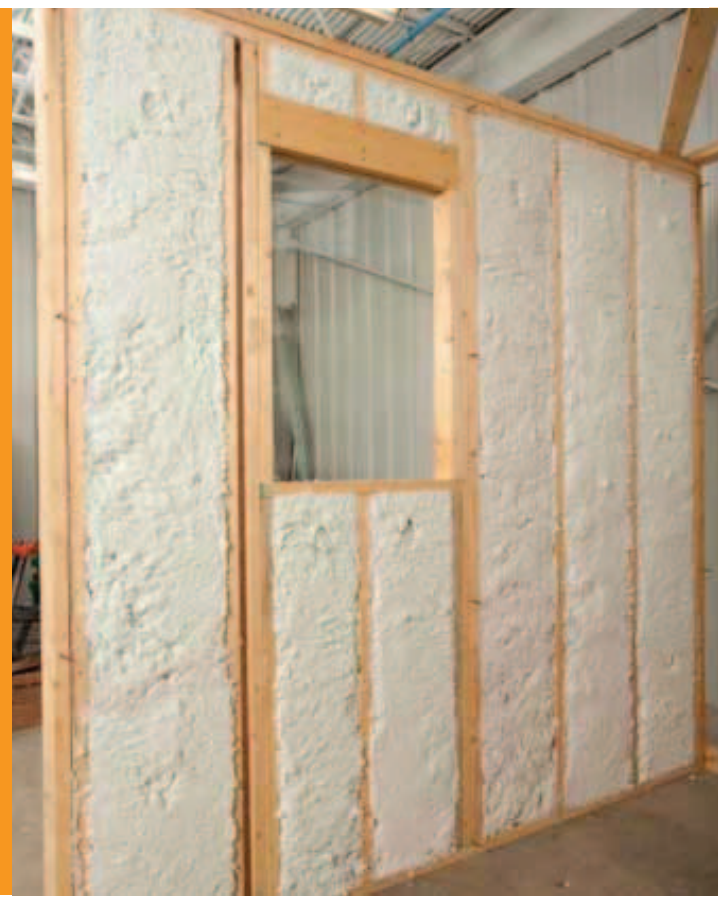

Knauf Insulation GmbH

One Knauf Drive

Shelbyville, IN 46176

Sales and Marketing $\quad 1-(800)$ 825-4434, ext. 8300

Technical Support $\quad 1-(800) 825-4434$, ext. 8212

Fax

1-(317) 398-3675

Information

info.us@knaufinsulation.com

World Wide Web

www.knaufinsulation.us

\begin{tabular}{|c|c|c|c|c|c|c|}
\hline \multicolumn{7}{|c|}{ Cavity Wall Application } \\
\hline Framing & $\begin{array}{l}\text { Cavity } \\
\text { Depth }\end{array}$ & $\begin{array}{l}\text { R-Value* }^{*} \\
\text { To obtain an } \\
\text { insulation } \\
\text { resistance } \\
\text { of: }\end{array}$ & Density & $\begin{array}{l}\text { Bags per } 1000 \mathrm{SF} \\
\text { The number of bags } \\
\text { per } 1,000 \text { square } \\
\text { feet of net area } \\
\text { should not be } \\
\text { less than: }\end{array}$ & $\begin{array}{c}\text { Maximum } \\
\text { Coverage } \\
\text { per Bag } \\
\text { Contents of this } \\
\text { bag should not } \\
\text { cover more than: }\end{array}$ & $\begin{array}{l}\text { Net Minimum } \\
\text { Weight per SF } \\
\text { The weight per } \\
\text { square feet of } \\
\text { installed insulation } \\
\text { should not } \\
\text { be less than: }\end{array}$ \\
\hline 2" x 4" & $3.50^{\prime \prime}$ & R-15 & $2.2 \mathrm{lbs} . / \mathrm{cu} . \mathrm{ft}$. & 21.4 bags & 46.8 sq. ft. & $0.64 \mathrm{lbs}$. \\
\hline $2 " \times 6 "$ & $5.50 "$ & R-23 & $2.2 \mathrm{lbs} . / \mathrm{cu} . \mathrm{ft}$. & 33.6 bags & 29.8 sq. ft. & $1.01 \mathrm{lbs}$. \\
\hline $2 " \times 8 "$ & $7.25 "$ & $R-31$ & $2.2 \mathrm{lbs} . / \mathrm{cu} . \mathrm{ft}$. & 44.3 bags & 22.6 sq. ft. & $1.33 \mathrm{lbs}$. \\
\hline 2" x 10" & $9.25 "$ & R-39 & $2.2 \mathrm{lbs} / / \mathrm{cu} . \mathrm{ft}$. & 56.5 bags & 17.7 sq. ft. & $1.70 \mathrm{lbs}$. \\
\hline
\end{tabular}

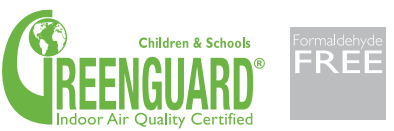

Knauf EcoFill ${ }^{\circledR}$ Wx Glasswool Blowing Insulation is certified for indoor air quality as a low emitting product by The GREENGUARD Environmental Institute to both the GREENGUARD Indoor Air Quality Cerrification Program ${ }^{S M}$ and the more stringent GREENGUARD Children \& Schools standard and is verified to be formaldehyde free.

www.greenguard.org

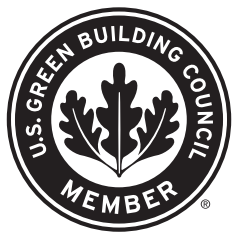

LEED Eligible Product

Use of this product may help building projects meet green building standards as set by the Leadership in Energy and Environmental Design (LEED) Green Building Rating System. Credit 4.1 - 4.2 Recycled Content Credit 5.1 - 5.2 Regional Materials

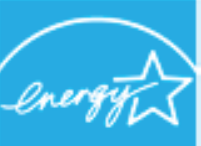

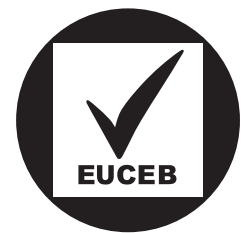

This product has been tested and is cerrified to meet the EUCEB requirements. 
Appendix A5.1:

Owens Corning ProPink L77

Documentation on Material Packaging 


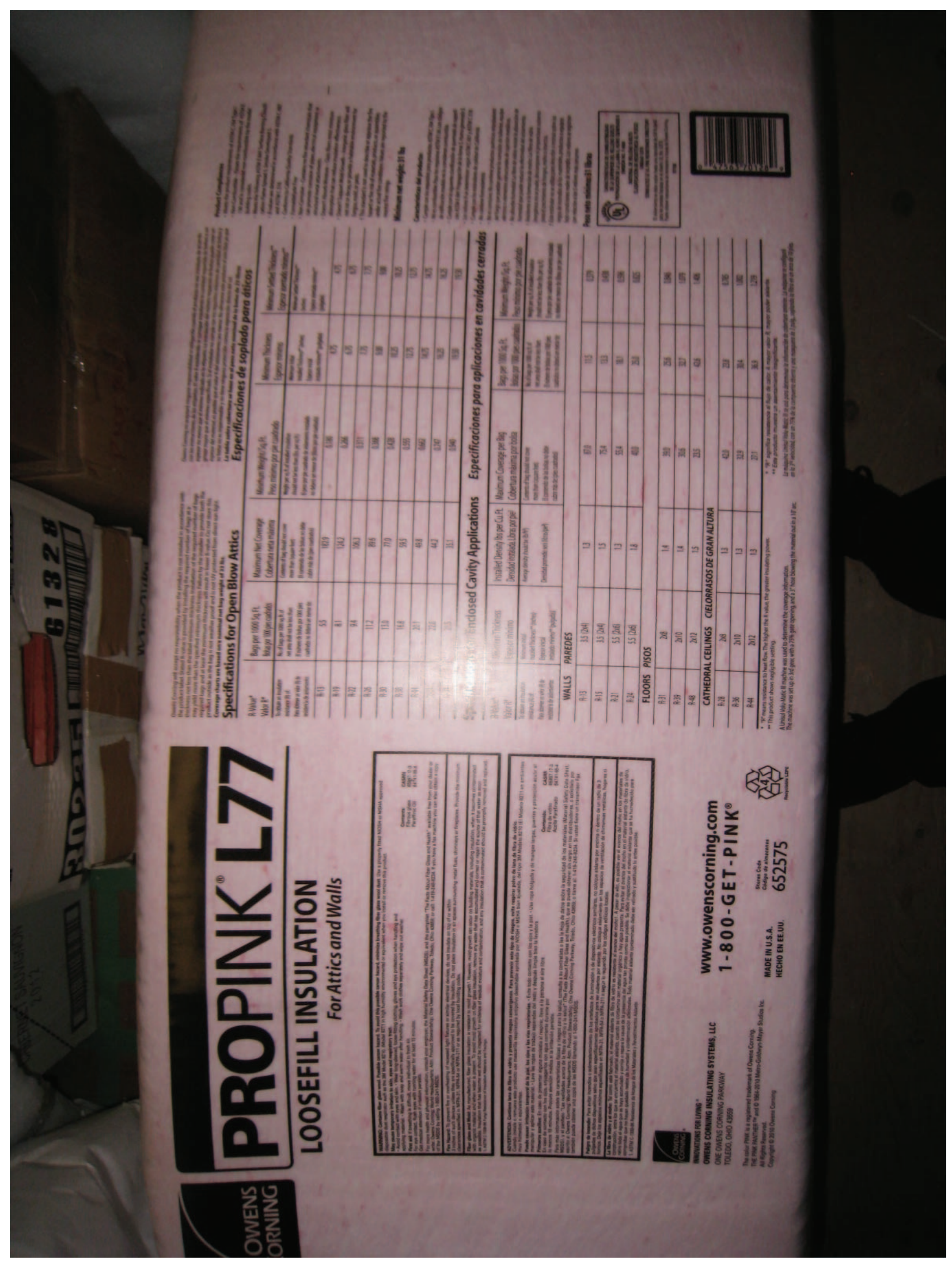




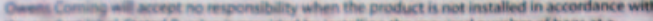

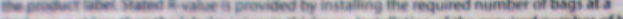

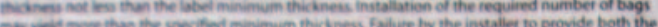

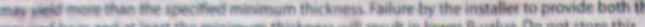

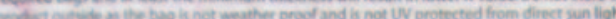

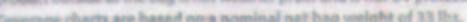
Specifications for Open Blow Antics

\begin{tabular}{|c|c|c|c|c|c|}
\hline $\begin{array}{l}\text { Plalue' } \\
\text { Valor } \mathrm{R}^{\prime \prime}\end{array}$ & 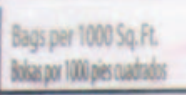 & $\begin{array}{l}\text { Maxinumin lat Coveage } \\
\text { Cobertura neta maxima }\end{array}$ & $\begin{array}{l}\text { Minimum lleight/Sq.Ft. } \\
\text { Peso minimo por pie cuadrado }\end{array}$ & $\begin{array}{l}\text { Minimum Thidiness } \\
\text { Espesorminimo }\end{array}$ & 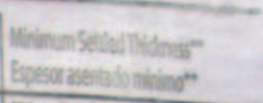 \\
\hline 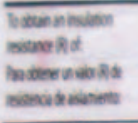 & 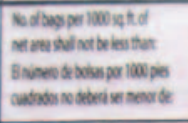 & 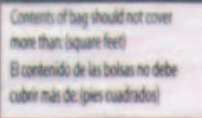 & 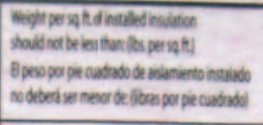 & 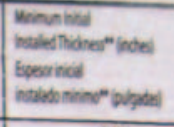 & 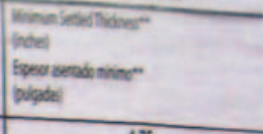 \\
\hline $8-13$ & 55 & 1829 & 0.180 & 475 & 475 \\
\hline$R \cdot 19$ & 8.1 & 1242 & 0.266 & 675 & $6 / 5$ \\
\hline$R 22$ & 9.4 & 1063 & 0311 & 735 & 175 \\
\hline$R \cdot 26$ & 112 & 89.6 & 0.368 & 900 & $9 x$ \\
\hline $8 \cdot 30$ & 130 & 770 & 0.428 & 1025 & 108 \\
\hline$R \cdot 38$ & 168 & 595 & 0.555 & 1275 & 125 \\
\hline$R 4$ & 20.1 & 49.8 & 0.662 & 1475 & 1475 \\
\hline$R-49$ & 226 & 442 & 0.747 & 1625 & 168 \\
\hline 8.60 & 285 & 35.1 & 0.940 & 1950 & 1950 \\
\hline
\end{tabular}

\section{Specifications for Enclosed Cavity Applications}

\begin{tabular}{|c|c|c|c|c|c|}
\hline $\begin{array}{l}\text { R.Value" } \\
\text { Valor } \mathrm{R}^{*}\end{array}$ & $\begin{array}{l}\text { Minimum Thickness } \\
\text { Espesor minimo }\end{array}$ & $\begin{array}{l}\text { Installed Density los per Cu.ft. } \\
\text { Densidad instalada libros por pies }\end{array}$ & $\begin{array}{l}\text { Maximum Coverage per Bag } \\
\text { Cobertura máxima por bolsa }\end{array}$ & $\begin{array}{l}\text { Bags per } 1000 \text { Sq fit } \\
\text { Bobss por 100 pee cuadrads }\end{array}$ & $\begin{array}{l}\text { Vininum lleight SaqR } \\
\text { Peso minimo por pie cadiado }\end{array}$ \\
\hline 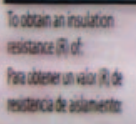 & 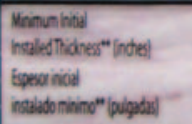 & 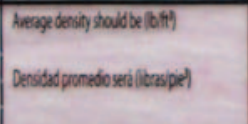 & 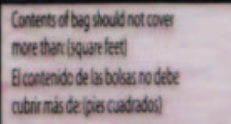 & 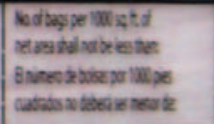 & 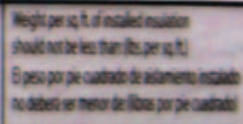 \\
\hline
\end{tabular}

\section{WALLS PAREDES}

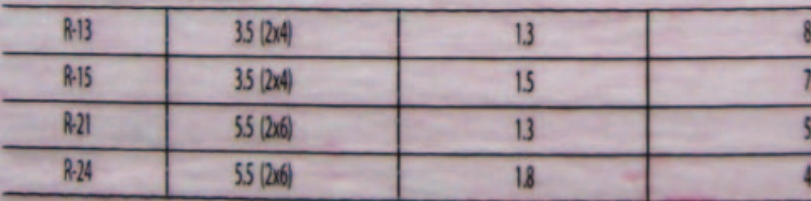

\section{FLOORS PISOS}

\begin{tabular}{l|l|l}
\hline$R .31$ & 28 & \\
\hline$R .39$ & 210 & \\
\hline$R .48$ & 212 & \\
\hline$C$ & 212 & \\
\hline
\end{tabular}

CATHEDRAL CEIIINGS CIELORRASOS De GRAN ALTURA

\begin{tabular}{l|l|l}
\hline$R 28$ & 28 & \\
\hline$R .36$ & 210 & \\
\hline$R 44$ & $2 \times 12$ & \\
\hline
\end{tabular}

- Treans resiatance to heat flow. The higher the R value the grater insulating powe: - Mis product thom negligite settling

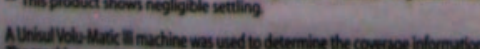

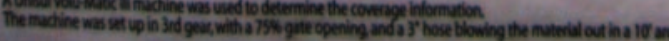

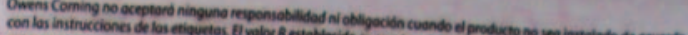

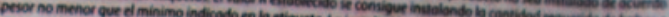
.

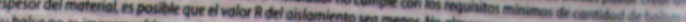
. Es

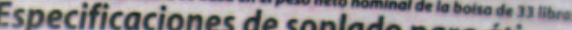

\begin{tabular}{|l|l|l|}
\hline 70 & 115 & (39) \\
\hline
\end{tabular}

\begin{tabular}{|c|c|c}
\hline 754 & 133 & 163 \\
\hline
\end{tabular}

\begin{tabular}{l|l}
534 & 18 \\
\hline 54 &
\end{tabular}

1002

15\%

QBS

1

\begin{tabular}{|l|l|l}
\hline 390 & 86 & 096 \\
\hline 306 & 320 & 109 \\
\hline 25 & 26 & 106 \\
\hline
\end{tabular}

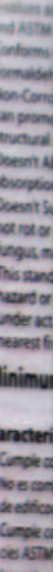

voraco

vivent

incionat

conse

sonet

elest

Sather

snelad

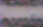

mexeda

regerd

$\cos x=$ anciar

Pesone 
Appendix A5.2a:

Owens Corning ProPink L77

Documentation for Dense-Packing

Brochure, "Introducing ProPink L77 Loosefill Insulation" 


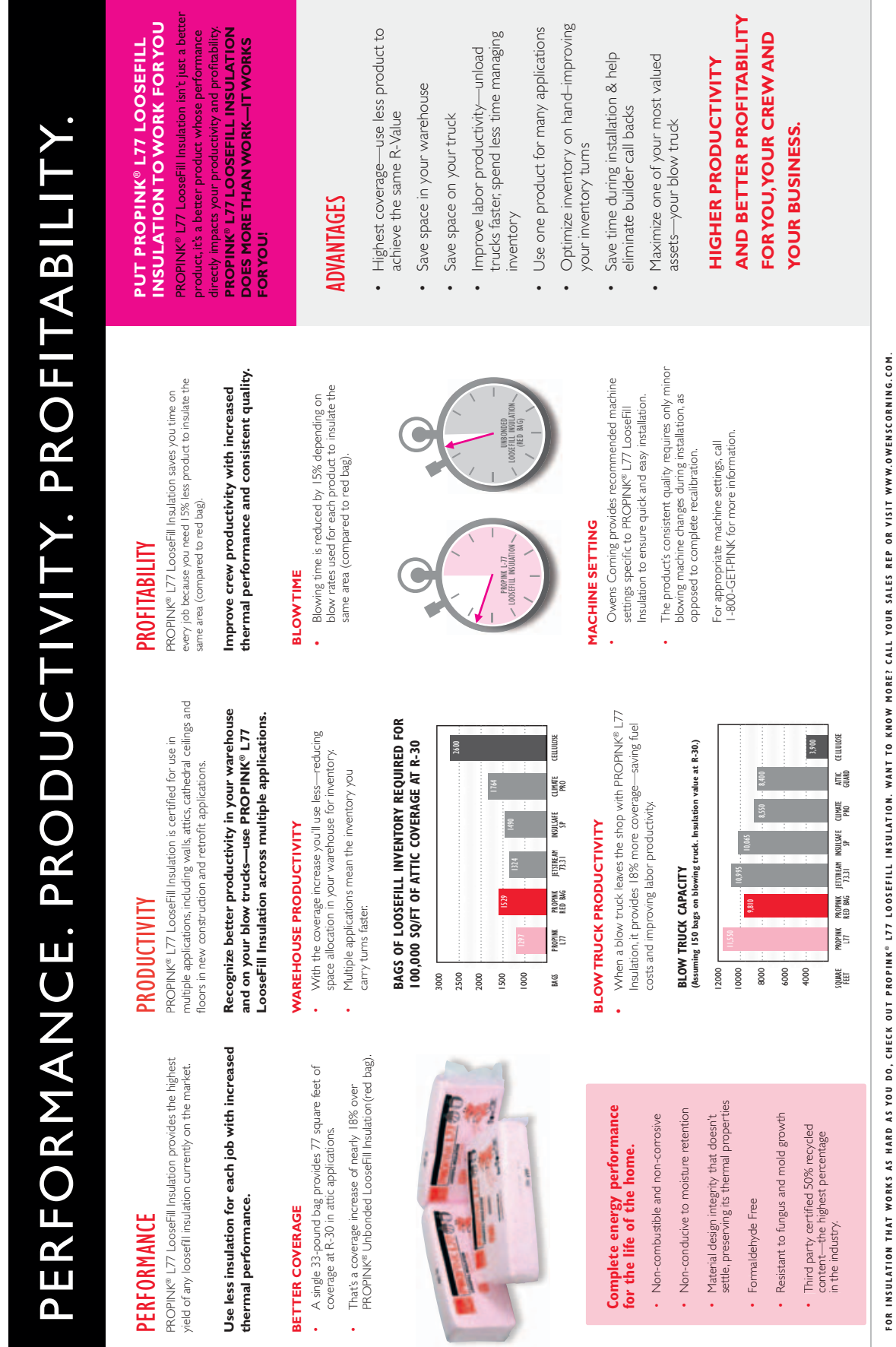




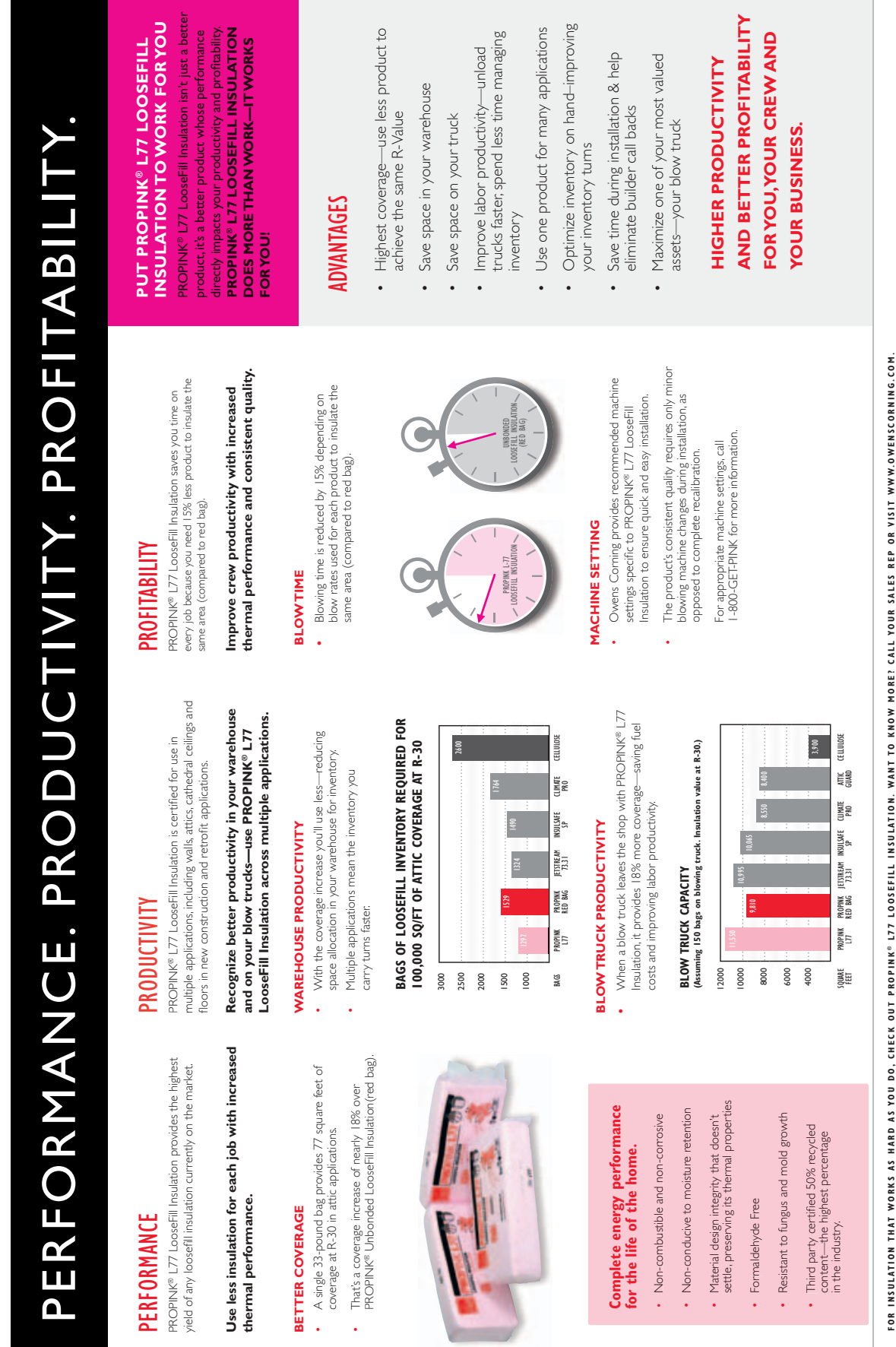




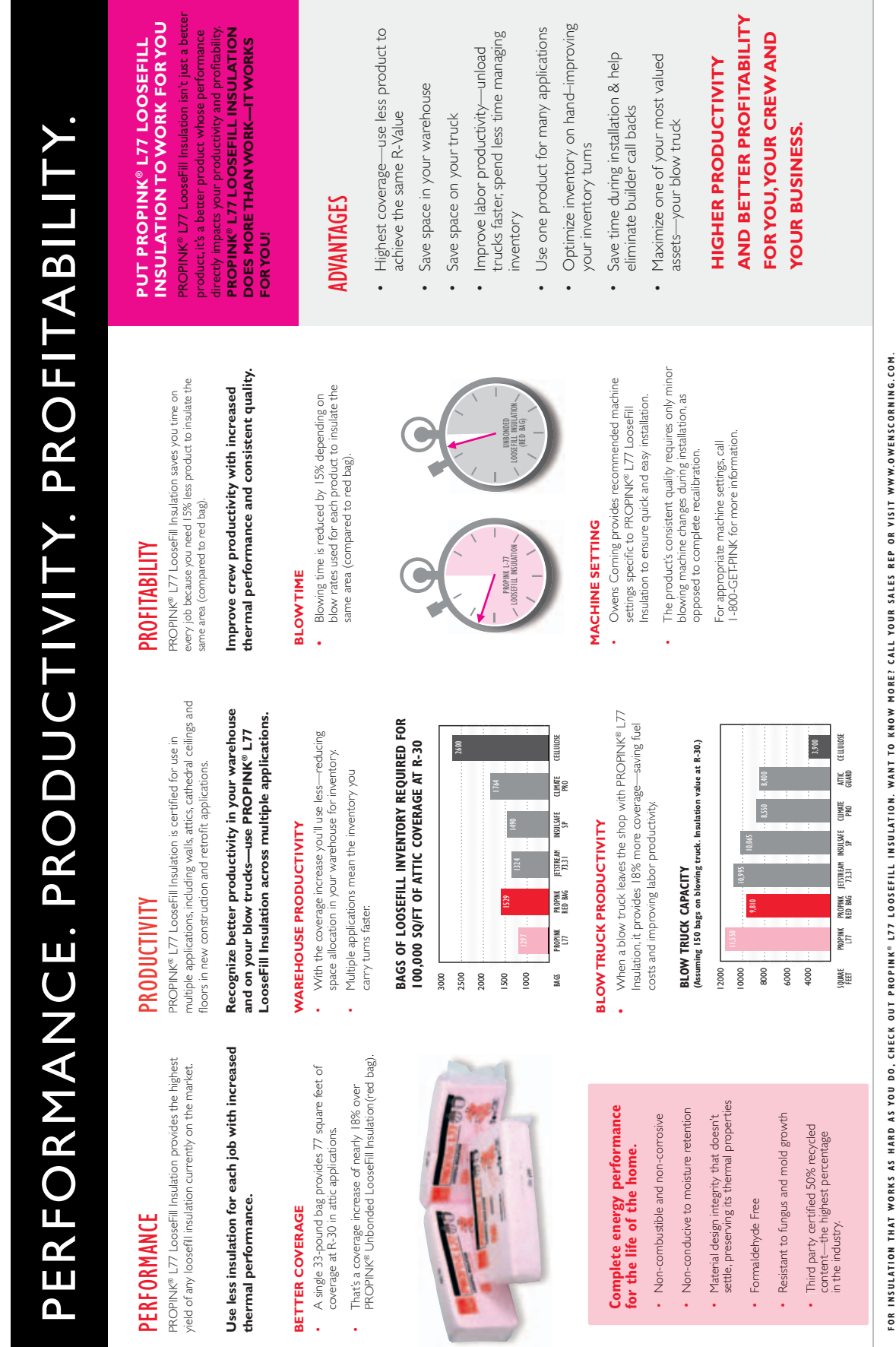


Appendix A5.2b:

Owens Corning ProPink L77

Documentation for Dense-Packing

Sell Sheet, "A New Standard for Insulation \& Air Infiltration" 


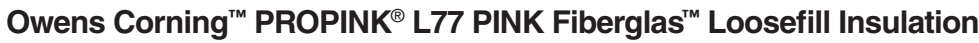

\section{A NEW STANDARD FOR INSULATION \& AIR INFILTRATION.}

The Ultimate In Air Infiltration and Thermal Performance.

When it comes to choosing insulation for weatherization projects in existing homes, many factors including thermal performance and air infiltration - come into consideration. Many people assume cellulose is the best choice. But there is a better choice - Owens Corning ${ }^{\text {Tw }}$ PROPINK ${ }^{\circledR}$ L77 PINK Fiberglas $^{\text {TM }}$ Loosefill Insulation delivers exceptional performance for air-infiltration control and thermal protection compared to cellulose insulation.

\section{New Formulation. New Dense-Packing Capabilities. New Standard In Performance.}

Owens Corning ${ }^{\text {Tw }}$ PINK Fiberglas Loosefill Insulation has been reformulated to make it more effective for use in wall applications.

- Easily installed in walls and improved nesting for compaction

- Can now be "dense packed" into walls at an installed density of up to 2.50 pounds per cubic foot*

- Achieves an airflow reduction equal to cellulose while providing $\mathrm{R}$-value greater than cellulose ${ }^{\star \star}$

Owens Corning' ${ }^{\text {'m }}$ PROPINK ${ }^{\circledR}$ L77 PINK Fiberglas'M Loosefill Insulation Cellulose

Source: Comparative Study on Air Infiltration by NAHB Research Center, 10/09

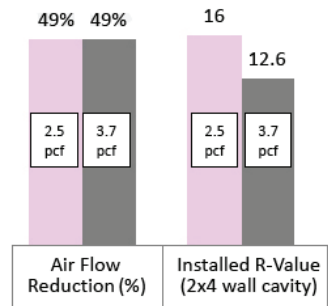

\section{Easy Installation.}

- Easily flows around obstacles within a wall cavity, allowing for complete and uniform cavity fill, especially for "drill and fill" applications

- Dense packing of PINK Fiberglas Loosefill Insulation can be achieved by professional installers using most machines that are currently used to blow either fiberglass or cellulose insulation into existing wall cavities

\section{Most tested. Most trusted.}

At Owens Corning, we apply over 70 years of building science expertise and rigorous testing to every product we make. Our PINK Fiberglas Loosefill Insulation products won't settle or deteriorate with age, so there's no danger of losing R-value over time. It's noncombustible, meeting all model building

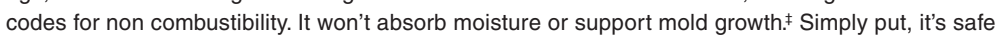
and one of the most effective insulation products you can use in a home.

Ensure that the wall system can withstand the additional forces before dense packing any insulation material. $R$-value means resistance to heat flow. The higher the $R$-value, the greater the insulating power. Ask your seller for the fact sheet on $R$-values. To get the marked $R$-value, it is essential that insulation be installed properly.

$+\quad$ PROPINK L77 PINK Fiberglas ${ }^{\text {TM }}$ Loosefill Insulation was tested using the Volumatic II. Results may vary based on equipment used.

F As manufactured, fiber glass insulation is resistant to mold growth (tested per ASTM C 1338). However, mold growth can occur on building materials, including insulation, when it becomes contaminated with organic material and when water is present. To avoid mold growth on fiber glass insulation, remove any water that has accumulated and correct or repair the source of that water as soon as possible. Insulation that has become wet should be inspected for evidence of residual moisture and contamination, and any insulation that is contaminated
should be promptly removed and replaced. should be promply remoud be is

Pub. No. 10011629. Printed in U.S.A. November 2009. The color PINK is a registered trademark of Owens Corning. O2009 Owens Corning. 
Appendix A5.3:

Owens Corning ProPink L77

Documentation for Weatherization / Retrofit

Fact Sheet, "ProPink L77 Pink Fiberglas Unbonded Loosefill Insulation" 


\section{PROPINK ${ }^{\circledR} \mathrm{L}^{2} 7$ PINK ${ }^{\circledR}$ Fiberglas $^{\text {TM }}$ Unbonded Loosefill Insulation}

INNOVATIONS FOR LIVING

\section{Manufacturers Fact Sheet}

This fact sheet contains important details about Owens Corning's ${ }^{\text {TM }}$ PROPINK ${ }^{\circledR}$ L77 PINK $^{\circledR}$ Fiberglas ${ }^{\mathrm{TM}}$ Unbonded Loosefill Insulation. Read it carefully.

Owens Corning will accept no responsibility when the product is not installed in accordance with the product label. Stated R-value is provided by installing the required number of bags at a thickness not less than the label minimum thickness. Installation of the required number of bags may yield more than the specified minimum thickness. Failure by the installer to provide both the required bags and at least the minimum thickness will result in lower insulation R-value.

\begin{tabular}{cccccc}
$\begin{array}{c}\text { Open Cavity Application (Attics) } \\
\text { Bags Per }\end{array}$ & $\begin{array}{c}\text { Maximum } \\
\text { R-value }\end{array}$ & $\begin{array}{c}\text { Minimum } \\
\text { I,000 Sq. Ft. }\end{array}$ & $\begin{array}{c}\text { Net Coverage } \\
\text { Weight/Sq. Ft. }\end{array}$ & $\begin{array}{c}\text { Minimum } \\
\text { Thickness (in) }\end{array}$ & $\begin{array}{c}\text { Minimum Settled } \\
\text { Thickness }\end{array}$ \\
R-13 & 5.5 & 182.9 & 0.180 & 4.75 & 4.75 \\
\hline R-19 & 8.1 & 124.2 & 0.266 & 6.75 & 6.75 \\
\hline R-22 & 9.4 & 106.3 & 0.311 & 7.75 & 7.75 \\
\hline R-26 & 11.2 & 89.6 & 0.368 & 9.00 & 9.00 \\
\hline R-30 & 13.0 & 77.0 & 0.428 & 10.25 & 10.25 \\
\hline R-38 & 16.8 & 59.5 & 0.555 & 12.75 & 12.75 \\
\hline R-44 & 20.1 & 49.8 & 0.662 & 14.75 & 14.75 \\
\hline R-49 & 22.6 & 44.2 & 0.747 & 16.25 & 16.25 \\
\hline R-60 & 28.5 & 35.1 & 0.940 & 19.50 & 19.50 \\
\hline
\end{tabular}

\section{Closed Cavity Application (Walls)}

\begin{tabular}{cccccc} 
R-value & $\begin{array}{c}\text { Minimum } \\
\text { Thickness }\end{array}$ & $\begin{array}{c}\text { Installed Density } \\
\text { Lbs. Per Cu. Ft. }\end{array}$ & $\begin{array}{c}\text { Maximum } \\
\text { Coverage Per Bag }\end{array}$ & $\begin{array}{c}\text { Bags Per } \\
\text { I,000 Sq. Ft. }\end{array}$ & $\begin{array}{c}\text { Minimum weight } \\
\text { Lbs. Per Sq. Ft. }\end{array}$ \\
\hline 13 & $3.5(2 \times 4)$ & 1.3 & 87.0 & 11.5 & 0.379 \\
\hline 15 & $3.5(2 \times 4)$ & 1.5 & 75.4 & 13.3 & 0.438 \\
\hline 21 & $5.5(2 \times 6)$ & 1.3 & 55.4 & 18.1 & 0.596 \\
\hline 24 & $5.5(2 \times 6)$ & 1.8 & 40.0 & 25.0 & 0.825 \\
\hline
\end{tabular}

Closed Cavity Application (Floors and Cathedral Ceilings)

\begin{tabular}{cccccc} 
R-value & $\begin{array}{c}\text { Minimum } \\
\text { Thickness }\end{array}$ & $\begin{array}{c}\text { Installed Density } \\
\text { Lbs. Per Cu. Ft. }\end{array}$ & $\begin{array}{c}\text { Maximum } \\
\text { Coverage Per Bag }\end{array}$ & $\begin{array}{c}\text { Bags Per } \\
\text { I,000 Sq. Ft. }\end{array}$ & $\begin{array}{c}\text { Minimum weight } \\
\text { Lbs. Per Sq. Ft. }\end{array}$ \\
\hline 31 & $7.25(2 \times 8)$ & 1.4 & 39.0 & 25.6 & 0.846 \\
\hline 39 & $9.25(2 \times 10)$ & 1.4 & 30.6 & 32.7 & 1.079 \\
\hline 48 & $11.25(2 \times 12)$ & 1.5 & 23.5 & 42.6 & 1.406 \\
\hline
\end{tabular}

I. This product shows negligible settling, with no impact on thermal performance.

Unisol Volu-Matic III machine was used to determine the coverage information above. The machine was set up in

3 rd gear, with a $75 \%$ open gate and a $3 "$ hose, blowing the wool out in a $10 \mathrm{ft}$. arc.

\section{Read This Before You Buy}

What you should know about R-Values:

The chart shows the R-values of this insulation. "R" means resistance to heat flow. The higher the R-value, the greater the insulating power. Compare insulation R-values before you buy.

There are other factors to consider. The amount of insulation you need depends mainly on the climate you live in. Also, your fuel savings from insulation will depend on the climate, the type and size of house, the amount of insulation already in your house, and your fuel-use patterns and family size. If you buy too much insulation, it will cost you more than what you'll save on fuel.

To get the marked R-value, it is essential that this insulation be installed properly.

\section{Please contact 419-248-6557 for additional information. Email: gettech@owenscorning.com}

Disclaimer of Liability

Technical information contained herein is furnished without charge or obligation and is given and accepted at recipient's sole risk. Because conditions of use may vary and are beyond our control, Owens Corning makes no representation about, and is not responsible or liable for the accuracy or reliability of data associated with particular uses of any product described herein.

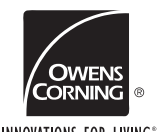

OWENS CORNING INSULATING SYSTEMS, LLC ONE OWENS CORNING PARKWAY

TOLEDO, OHIO, USA 43659

1-800-GET-PINK ${ }^{\circledR}$

INNOVATIONS FOR LIVING ${ }^{\circ}$ WwW.owenscorning.com

Pub. No. 22676-I. Printed in U.S.A. December 2012. THE PINK PANTHER ${ }^{\text {TM }}$ \& (C1964-2012 Metro-Goldwyn-Mayer Studios Inc. All Rights Reserved. The color PINK is a registered trademark of Owens Corning. (C2012 Owens Corning. All Rights Reserved. 


\section{Appendix B: Loose-Fill Stone Wool Insulation Products (Not Intended for Dense-Pack Retrofit Applications)}

- Amerrock RockWool Premium Plus

- Rolan Fibra Mineral Nodular

- Roxul Rockfill

- Thermafiber Spray Wool 
Appendix B1:

Amerrock RockWool Premium Plus 


\section{RockWool Premium Plus \\ Triple Protection Insulation}

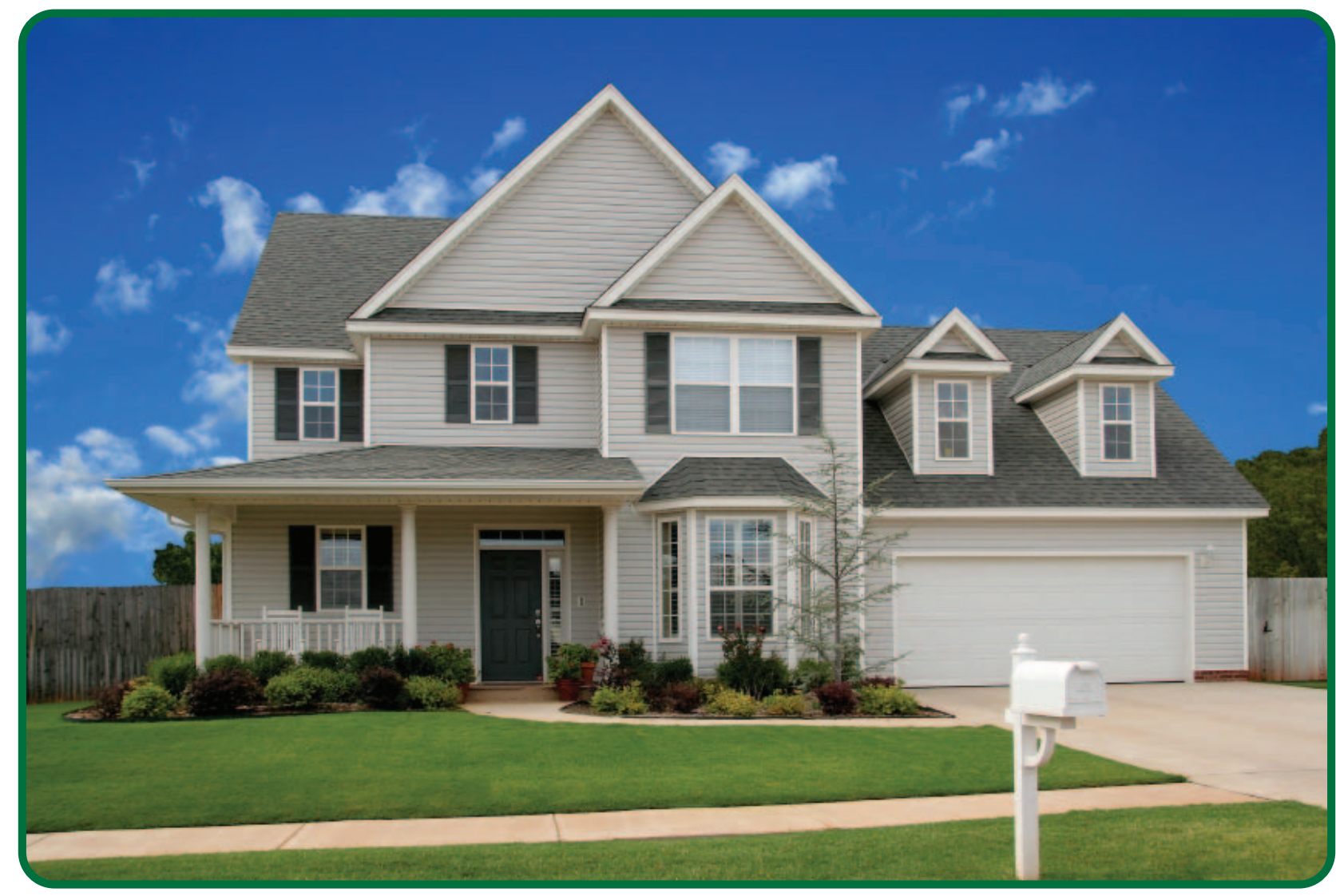

\section{One Product with 5 Extraordinary Benefits...}

- Green - 60\% Recycled, 45\% Sustainable

- Inorganic - Resists, Mold, Mildew, \& Fungus

- Fireproof - Listed by UL as NON-Combustible

- Thermal Performance - R-Values of 4.1 per Inch!

- Sound Control - STC Ratings as high as 69

\section{Amerrock Products}

manufacturer of premium rockwool products

Submittal Approval: Job Name: 
DESCRIPTION: Rock Wool Premium Plus ${ }^{\mathrm{TM}}$ Insulation is a high quality mineral fiber manufactured in a granular form. This product is noncombustible, moisture-resistant, non-corrosive, non-deteriorating, mildew-proof and vermin-proof. With the addition of Rock-Tight'M Adhesive, Rock Wool Premium Plus $^{\mathrm{TM}}$ Insulation can be sprayed overhead which allows the design professional greater flexiblity with their designs.

INSTALLATION: Caulk all framing abutments, windows, and door placements. Where required, fill with acceptable fire-stopping material any areas that cannot be adequately reached with pneumatic fill of Rock Wool Premium Plus ${ }^{\mathrm{TM}}$ Insulation. Install the insulation into the area to be filled using specified pneumatic equipment. If using Rock-TightTM adhesive the equipment must be fitted with an auxiliary liquid high pressure line designed to uniformly add adhesive to the Rock Wool Premium Plus TM Insulation. The moisture content should not exceed $10 \%-15 \%$ maximum. The insulation must be sprayed using only approved materials and equipment in accordance with the current installation instructions. For complete installation instruction visit our website at www.amerrock.com

Design Considerations: Rock Wool Premium Plus ${ }^{\mathrm{TM}}$ Insulation must be installed in conditions that enable activation of the adhesive. Sprayed cavities must be dry before enclosing with gypsum wallboard. Generally 3-1/2" fills will be dry in 24 hours or less. 5-1/2" and greater will take longer depending on weather conditions. Allow extra time for low temperatures or high humid conditions. Consult your Amerrock Sales Representative for installation practices below $40^{\circ} \mathrm{F}$.

Product Data: Rock Wool Premium Plus ${ }^{\mathrm{TM}}$ Insulation is packaged in $30 \mathrm{lb}$. bags and should be stored under roof and in a dry location. Rotate stock. Do not stack more than 11 bags high.

\section{Technical Data:}

\begin{tabular}{|c|c|c|c|c|}
\hline \multirow{2}{*}{ Thickness } & \multirow{2}{*}{$\begin{array}{c}\text { Nominal } \\
\text { Density }\end{array}$} & $\begin{array}{c}\text { Tested to } \\
\text { ASTM C 518 }\end{array}$ & \multicolumn{2}{|c|}{ Tested to ASTM E 84 } \\
\cline { 3 - 4 } & & R-Value & $\begin{array}{c}\text { Flame } \\
\text { Spread }\end{array}$ & $\begin{array}{c}\text { Smoke } \\
\text { Development }\end{array}$ \\
\hline $3.5 "$ & 4 pcf & $\begin{array}{r}\text { R-15 } \\
\text { R-23.5 }\end{array}$ & & \\
$5.5 "$ & & R-30 & \multirow{2}{*}{5} & 0 \\
\hline $8.8 "$ & & R-38 & & \\
$11.2 "$ & 1.7 pcf & R-49 & & \\
$14.4 "$ & & & & \\
\hline
\end{tabular}

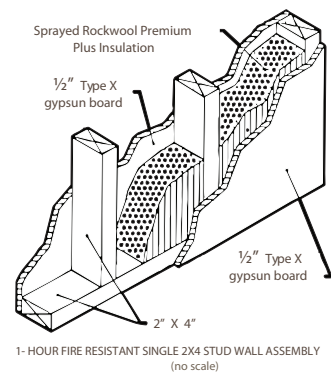

\section{Standard Compliance:}

\section{ASTM E 136}

ASTM E 1 19-83

ASTM E 119-88

ASTM E 1 19-00

ASTM E 283-04

ASTM E 413

ASTM E 605

ASTM C 1014

ASTM C 739

ASTM C 553

ASTM C 665

ASTM C 1338

ICC-ES Report 9551A

UL Classified per Follow-up R14191

Approved by the New York City Board of Standards and Appeals under MEA \#352-98-M

*Test was conducted using Amerrock Products Rock-Tight Adhesive
Non-Combustible

1 - Hour Fire Wall

2 - Hour Load Bearing Fire Wall (1250 lbs.)

Std Test Methods for Fire Tests of Bldg. Const. \& Mat'ls

Rate of Air Flow (1.83 cfm/sf @ 50 Pa \& 3.68 cfm/sf @ 75 Pa)

Sound Isolation Rating (various assemblies up to STC 69)

Standard Test Methods for Thickness and Density

Standard Specification for Spray Applied Mineral Fiber

Smoldering Combustion (Pass)

Moisture Absorption (Pass)

Non Corrosive (Pass)

Mold \& Fungus Resistance (Pass)

Fire Resistive Construction 
Appendix B2:

Rolan Fibra Mineral Nodular 


\section{Fibra Mineral Nodular Rolan*}

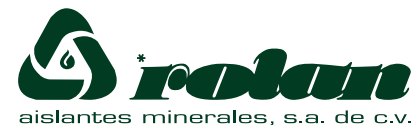

\section{Descripción}

La Fibra Mineral Nodular Rolan* es un termoaislante nodulizado compuesto por fibras minerales de roca de alta calidad, resistentes a la alta temperatura y contiene resina termofija como aglutinante que le da flexibilidad y baja densidad instalada.
A temperatura ambiente, la densidad debe ser entre 40 y $48 \mathrm{~kg} / \mathrm{m}^{3}\left(2.5\right.$ a $\left.3 \mathrm{lb} / \mathrm{ft}^{3}\right)$. En aplicaciones hasta $250{ }^{\circ} \mathrm{C}$, la densidad instalada debe ser de $64 \mathrm{~kg} / \mathrm{m}^{3}$ $\left(4 \mathrm{lb} / \mathrm{ft}^{3}\right)$ y arriba de $250{ }^{\circ} \mathrm{C}$ no debe ser menor a $96 \mathrm{~kg} / \mathrm{m}^{3}\left(6 \mathrm{lb} / \mathrm{ft}^{3}\right)$.

\section{Presentación}

Se suministra en sacos de polietileno de $14 \mathrm{~kg}$.

\section{Aplicaciones}

La Fibra Mineral Nodular Rolan* es apropiada para usarse en un amplio rango de temperaturas.

Se instala en cavidades y espacios en los que no puede aplicarse una placa, rollo o cualquier producto preformado.
Los espacios en los que se instala la fibra deben poder soportar sin deformarse, la presión interna ejercida por la compresión necesaria para lograr la compactación de la fibra.

Puede ser aplicada manualmente o con equipo neumático; se compacta solo en forma manual.

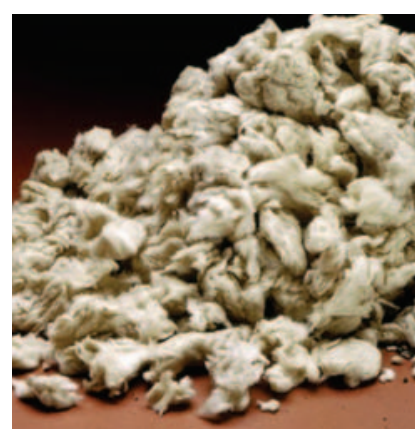

\section{Beneficios}

- Alta eficiencia térmica.

- Ahorra costos energéticos y de instalación.

- Amplio rango de temperaturas.
- Versatilidad de ajustar la densidad.

- Fácil de instalar.

\section{Cumplimiento de normas}

NOM-009 ENER Eficiencia energética en aislamientos térmicos industriales.

ASTM C-764 Fibras granulas.

ASTM C-519 Densidad de fibras minerales.
ASTM C-356 Encogimiento lineal.

ASTM C-411 Comportamiento sobre la superficie caliente.

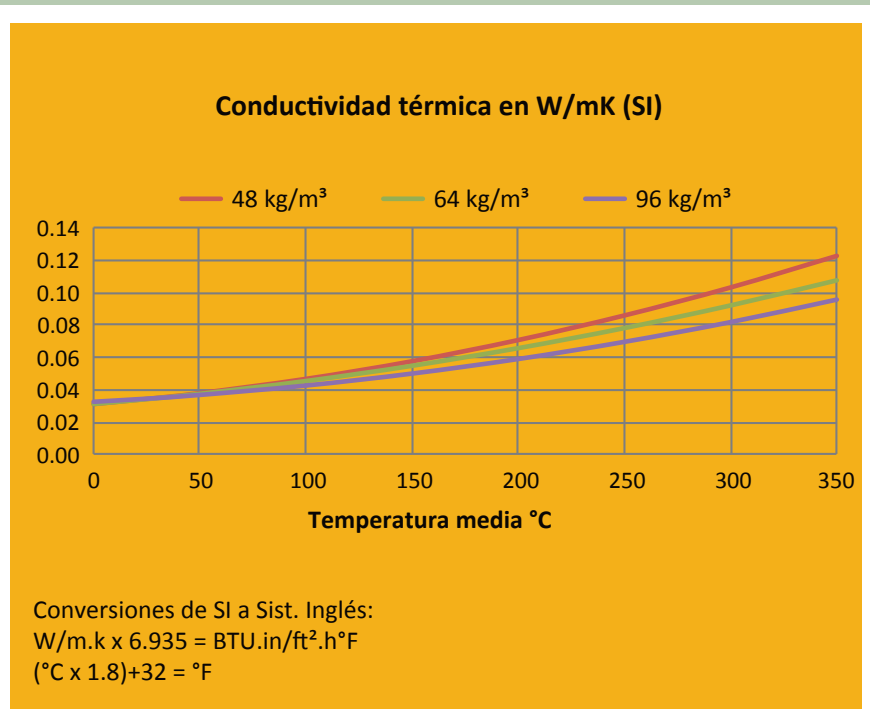

\section{Datos técnicos}

Temperatura de uso:

Asbesto:

Absorción de humedad:

Alcalinidad:

Comportamiento al fuego:

- Propagación de flama:

- Generación de humo:

Corrosividad:

Resistente a bacterias y hongos.
Desde $-49^{\circ} \mathrm{C}$ hasta $650^{\circ} \mathrm{C}$. No contiene.

$<1.0 \%$ en volumen.

pH entre 7.5 y 10.

Según ASTM E-84.

0

0

Nula. 
Appendix B3:

Roxul Rockfill 


\section{ROXUL \\ s RockFill \\ Top Up Attic Insulation}

\section{General Product Information:}

ROXUL ${ }^{\circledR}$ products are stone wool fiber insulations made from basalt rock and slag. This combination results in a noncombustible product with a melting point of approximately $2150^{\circ} \mathrm{F}\left(1177^{\circ} \mathrm{C}\right)$, which gives it excellent fire resistance properties. ROXUL stone wool is a water repellent yet vapour permeable material.

\section{Description \& Common Applications:}

ROXUL ROCKFILL ${ }^{T M}$ is a loose fill stone wool insulation for use in residential construction and attic renovations. ROCKFILL is designed to be easily aerated and spread out by hand, filling gaps in hard-to-reach places without requiring a blowing machine. The special characteristics of stone wool result in a light weight, water repellent, fire resistant and sound absorbing insulation that will not grow mold or mildew.

ROCKFILL does not move or settle over time, maintaining expected R-value.

\section{Compliance and Performance:}

CAN/ULC-S702

CAN/ULC-S114

CAN/ULC S102

CAN/ULC-S129

NBC 1995, Article

9.25.2.2

Thermal Resistance:

ASTM C 518 (C 177)

R-value/inch @ 75 F

RSI value/25.4 mm @ $24^{\circ} \mathrm{C}$
Type 4, Complies Non-Combustible Flame Spread $=0$ Smoke Developed $=0$ Mass Loss $<0.03 \%$ Conforms

$2.9 \mathrm{hr} . \mathrm{ft}^{2} . \mathrm{F} / \mathrm{Btu}^{* * *}$

$0.52 \mathrm{~m}^{2} \mathrm{~K} / \mathrm{W}$

\section{Installation:}

Installation in 3 easy steps

1) OPEN

Cut open and remove from bag

\section{2) AERATE}

Fluff product to aerate
3) SPREAD

Spread out evenly

Cover exposed skin. When working un unventilated areas, wear a disposable mask. Clean the area using vacuum equipment. Dispose of waste according to local regulations. Rinse hands in cold water before washing. Ventilate working area if possible. Wear goggles when working overhead. 
This product has been specifically designed to meet your needs for attic insulation.
Key Application Qualifiers:

- Easy to install

- No blowing machine required

- Stays in place for even comfort

- Fills gaps in hard-to-reach areas

- Non-combustible

- Excellent sound absorbency

- Chemically inert

- Does not rot or sustain vermin

- Does not promote growth of fungi or mildew

- Low moisture sorption

- Water resistant

- CFC- and HCFC- free product and process

- Made from natural \& recycled materials

\begin{tabular}{|l|c|c|c|c|c|c|}
\hline \multirow{2}{*}{$\begin{array}{l}\text { Desired } \\
\text { R-Value }\end{array}$} & $\begin{array}{l}\text { Thickness } \\
\text { Needed } \\
\text { (inches) }\end{array}$ & \multicolumn{4}{|c|}{ Number of Bags Required at Various Square } & $\begin{array}{l}\text { Coverage } \\
\text { per single } \\
\text { bag (Sq ft) }\end{array}$ \\
\hline & & $\mathbf{5 0 0}$ & $\mathbf{7 5 0}$ & $\mathbf{1 0 0 0}$ & $\mathbf{1 5 0 0}$ & \\
\hline R-12 & 4.25 & 8 & 12 & 16 & 24 & 63.50 \\
\hline R-20 & 7 & 14 & 20 & 27 & 40 & 38.09 \\
\hline R-24 & 8.5 & 16 & 24 & 32 & 48 & 31.74 \\
\hline R-28 & 9.75 & 19 & 28 & 37 & 56 & 27.21 \\
\hline R-32 & 11 & 21 & 32 & 42 & 63 & 23.81 \\
\hline R-36 & 12.5 & 24 & 36 & 48 & 71 & 21.16 \\
\hline R-40 & 13.75 & 27 & 40 & 53 & 79 & 19.04 \\
\hline R-50 & 17.25 & 33 & 50 & 66 & 99 & 15.23 \\
\hline
\end{tabular}

\section{QREENGUARR"}

\section{Other ROXUL Products:}

Please consult ROXUL for all your insulation needs. We have an extensive range of products for all applications from pipe insulation to commercial products to residential batts. ROXUL invites all inquiries and will act promptly to service all of your requirements.

Note:

As ROXUL Inc. has no control over installation design and workmanship, accessory materials or application conditions, ROXUL Inc. does not warranty the performance or results of any installation containing ROXUL Inc's. products. ROXUL Inc's. overall liability and the remedies available are limited by the general terms and conditions of sale. This warranty is in lieu of all other warranties and conditions expressed or implied, including the warranties of merchantability and fitness for a particular purpose.

$\begin{array}{lr}\text { ROXUL INC. } & \text { Milton, Ontario Tel: } \mathbf{9 0 5 - 8 7 8 - 8 4 7 4} \\ \text { www.roxul.com } & \text { Tel: } 1-800-265-6878\end{array}$

Fax: 905-878-8077

Fax: 1-800-991-0110

Revised: September 24th, 2013 Supersedes: September 14th, 2012 
Appendix B4:

Thermafiber Spray Wool

(Document covers many of Thermafiber's Granulated Products) 


\section{Thermafiber $^{\circledR}$ Granulated Products Selection Guide}

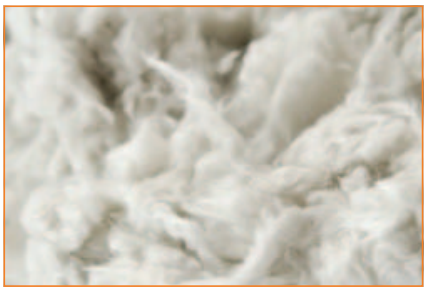

Industrial Bulk Wool: General use product where thermal and acoustical properties are the main concerns. End user is typically not concerned with color, shot, coatings, or nodule size.

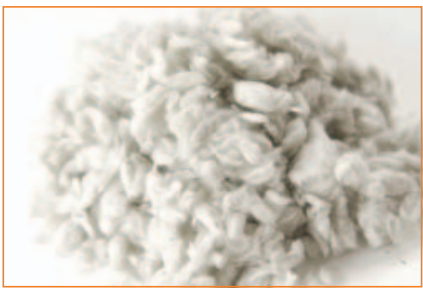

\section{Packing Wool}

- Purpose: Thermal Efficiency, Acoustical Performance.

- Characteristics: Mineral Wool formed into medium or regular sized nodules.

- Granulated - Poured in at a density of 4.0 pcf has an $800^{\circ} \mathrm{F}$ continuous operating temperature rating.

- Granulated - Packed in at a density of 8.0 pcf has a $1,200^{\circ} \mathrm{F}$ continuous operating temperature rating.

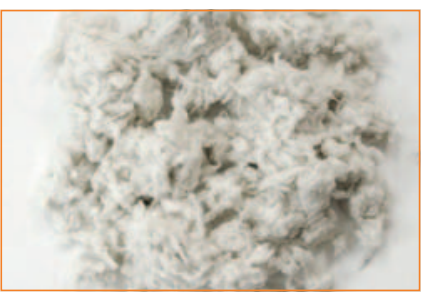

\section{Spray Wool - Pneumatically applied}

- Same product as Industrial Bulk Wool except is white in color.

- Typical uses include applications where spray applying bulk wool is less labor intensive than hand packing.

- Can be blown loose or with an adhesive.

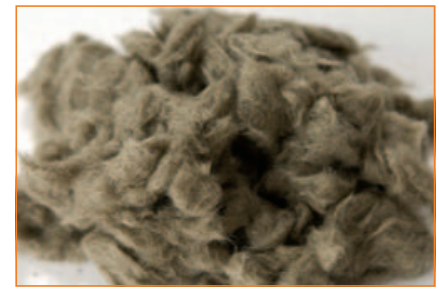

\section{High Performance (HP) Wool - Packing}

- Purpose: Higher temperature applications above $1,200^{\circ} \mathrm{F}$ up to $1,900^{\circ} \mathrm{F}$ continuous operating temperature. Must be installed (packed) at a density of $14.0 \mathrm{pcf}$ for application at $1.900^{\circ} \mathrm{F}$.

- Characteristics: Darker wool due to higher iron content, less shrinkage, better thermal conductivity.

- Typical uses for higher temperature applications where service temperatures are expected above $1,200^{\circ} \mathrm{F}$ to $1,900^{\circ} \mathrm{F}$ max.

- Also used as imitation (glowing) embers in gas fireplaces.

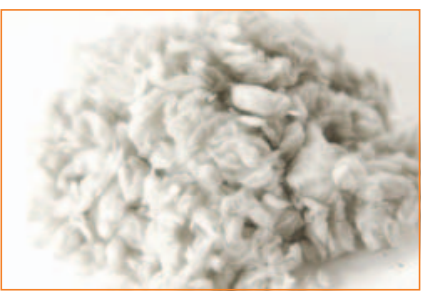

\section{Industrial \#10 Granulated Wool - Packing}

- Purpose: Same as Industrial Bulk Wool however, material is identified as Industrial \#10 Granulated Wool for approved use in U.S. Coast Guard Specification 164.009/169/0. 


\section{Thermafiber ${ }^{\circledR}$ Filler/Reinforcement Wool (FRF)}

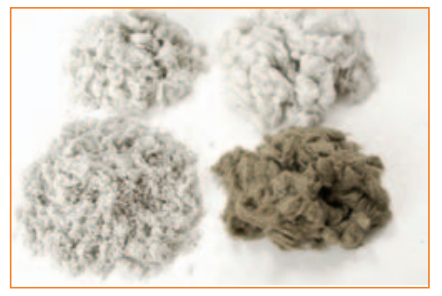

FRF Wool: FRF is a granulated product where characteristics such as nodule size, color, chemistries, coatings, and shot contents are important to the application. This type of loose fiber was entered into the market with a numbering system to easily identify the unlimited combinations of different custom features this type of product has to offer.

\section{Examples of Features:}

- Color - white, off white, and dark color.

- Nodule size - Milled to large.

- Treatments - Silicone \& Surfactant coatings to repel or absorb moisture/water.

- Oil content - Low (0.2\%) to high (1.0\%).

- Shot content - FRF contains a maximum of $50 \%$ shot content or non-fibrous solids on 325 screen. Shot content varies by product.

\section{Determining which FRF Product to use is based upon the following criteria:}

- Where will it go?

- How is the FRF going to be installed? - Packed, sprayed, added to another product?

- Are there temperature requirements in the application?

- What nodule size is needed? - Nodule size as small as a BB, or as large as a cotton ball?

- Is the color important?
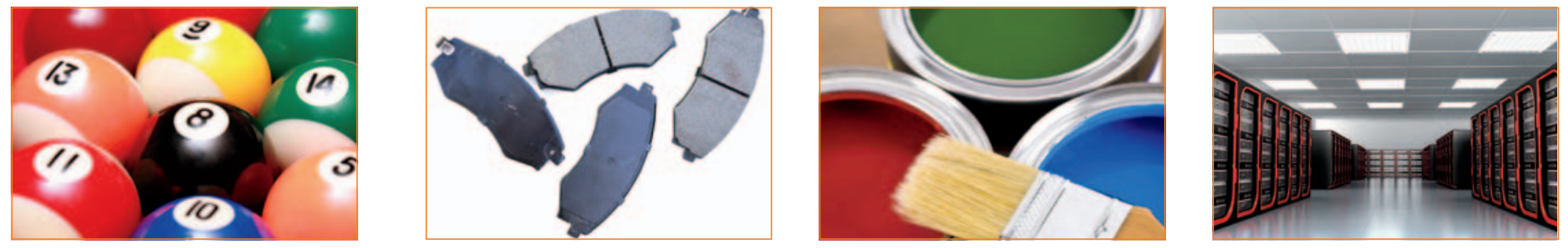

\section{Typical applications for Thermafiber FRF:}

- FRF 502: Typical application: Mineral wool fibers provided to brake manufactures for replacement of asbestos in brake formulations.

- FRF 511 or FRF 512: Typically used as a filler in wet slurry applications such as vacuum forming, ceiling tile production or coatings.

- FRF 514: Made with smaller nodule size (BB size) to pour into small openings typically $1-1 \frac{1}{2}$ " wide. it can be used for blending into batch of slurry applications where fiber dispersement is critical.

- FRF 114: A further refined nodule that provides a non-fibrous content of less than $5 \%$.

Notice:

For Further Information:
THERMAFIBER, Inc. shall not be liable for incidental and consequential damages, directly or indirectly sustained, nor for any loss caused by application of these goods not in accordance with current printed instructions or for other than the intended use. THERMAFIBER liability is expressly limited to replacement of defective goods. Any claim shal be deemed waived unless made in writing within thirty (30) days from date it was or reasonably should have been discovered. LEED® is a registered trademark of the US Green Building Counci

For more information on Thermafiber Industrial Bulk Wool or FRF products contact Thermafiber's Technical Services Department at 1-888-834-2371 or visit our website www.thermafiber.com.
Minimum

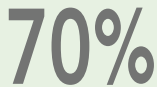

Recycled

Content 
Appendix C: Example of Dense-Packing Instructions From a Cellulose Insulation Manufacturer 
Retrofitting Existing Sidewalls with GreenFiber Insulation Contractor Work Instructions
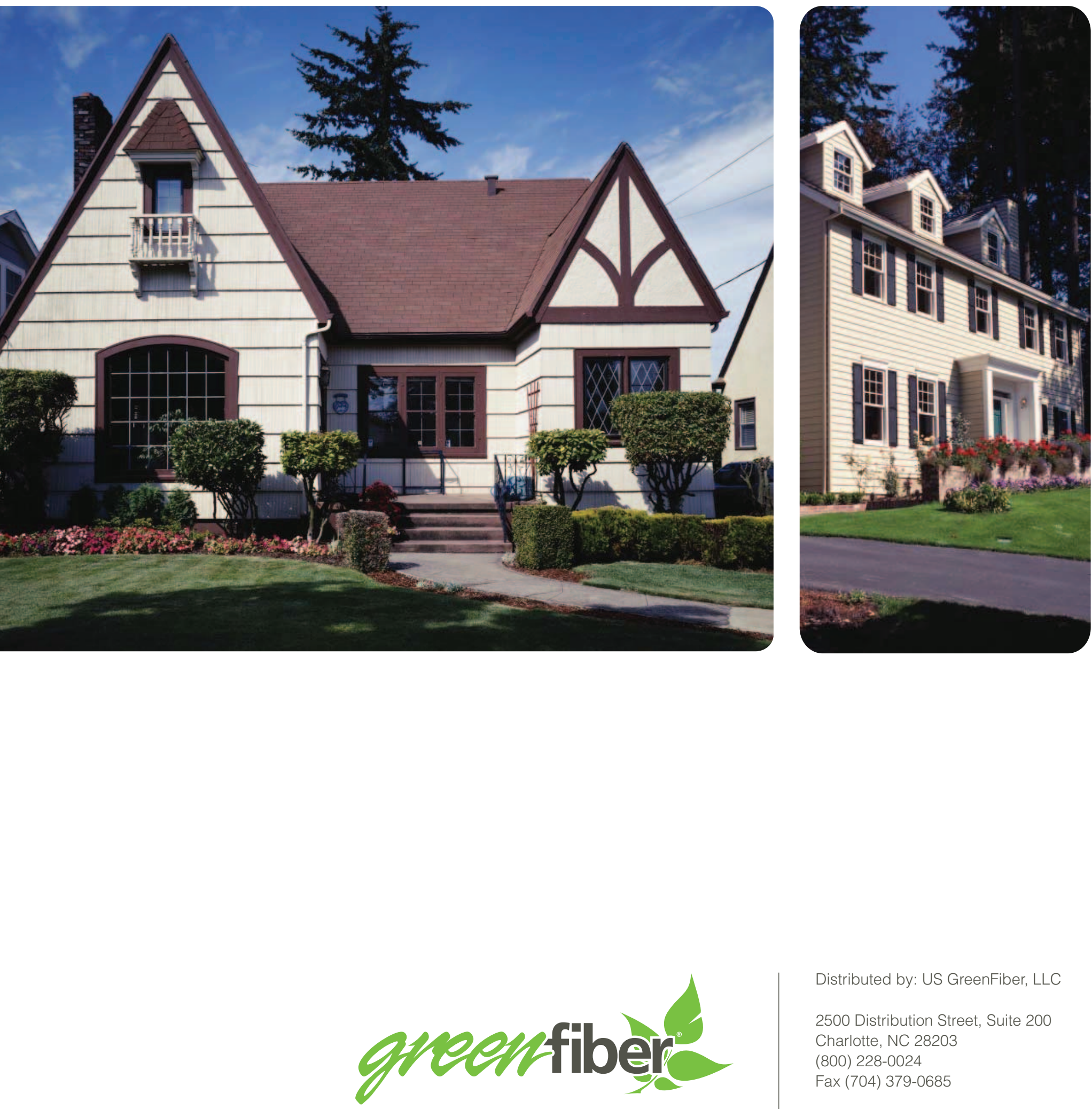

Distributed by: US GreenFiber, LLC 


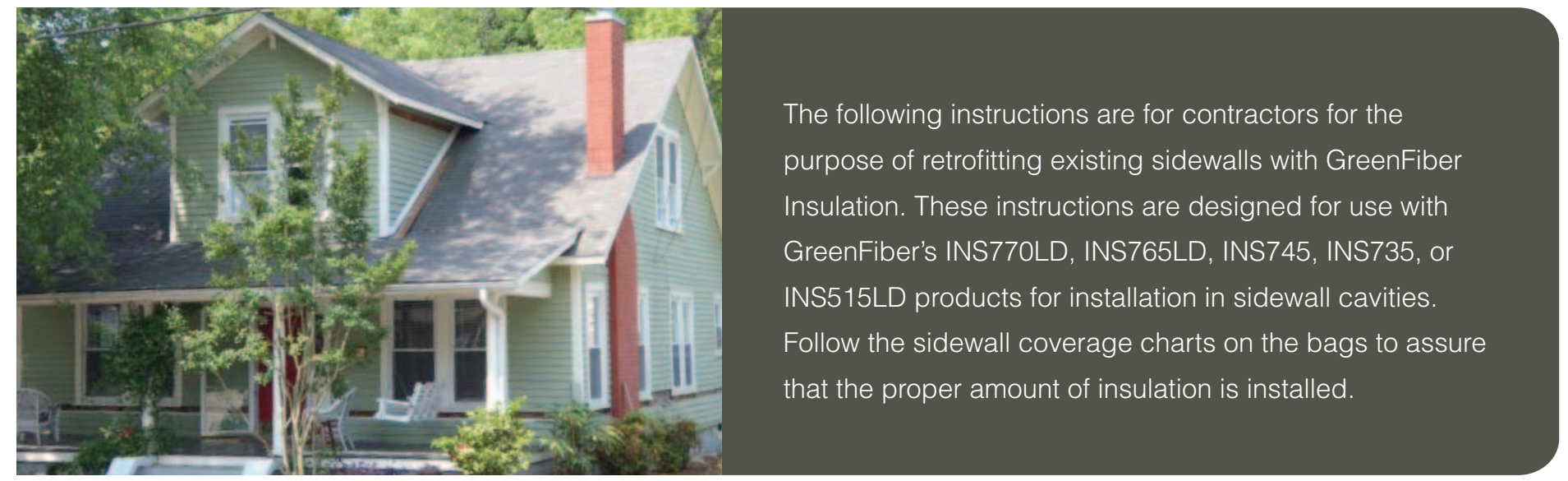

\section{Before Installation}

Retrofitting any part of a home's envelope will cause changes in air, heat and moisture flow. Contractors must understand how this installation will impact the house, i.e., ventilation and combustion air requirements. Examine both the inside and outside of a home to determine areas that are inappropriate for installation. For example:

- Do not insulate any home that has active knob and tube wiring.

- Where moisture related problems are evident, the source of the problems must be determined and corrected before proceeding.

- Do not install insulation in stud runs where heat-producing devices such as an unprotected chimney, a fireplace, etc. might cause severe overheating.

- Building assembly details such as balloon framing, fire blocking, pocket door connections, dry wall gaps or other leak points must be taken into consideration when blowing GreenFiber Insulation into a house.

- GreenFiber's Material Data Safety Sheet (MSDS) requires the use of safety eyewear when installing this product. The insulation contractor is responsible for managing housekeeping and engineering controls below nuisance dust levels. Follow all OSHA guidelines for safety requirements including 29 CFR 1926.501 Duty to Have Fall Protection. Various other local, state and federal rules and guidelines may apply.

\section{Application}

There are two basic techniques (Two-Hole or Double-Blow Method and One-Hole Tube Fill Method) used to fill existing, enclosed sidewall cavities. These techniques can be performed from either the exterior or interior of a home.

Installation through the interior wall is very difficult and is not detailed here. While it can be done, there is a wide range of other considerations related to someone currently occupying the home that present challenges to interior wall installation.

\section{Required Equipment:}

- Insulation blowing machine capable of at least 2.9 psi at the end of the hose

- Not all insulation blowing machines meet this requirement; please check with GreenFiber Customer Service 800.228.0024 - for verification.

- 1/4-inch fiberglass rod

- Hose clamps

- Utility knife

- Filter (such as sponge)

- Wood, plastic, cork or Styrofoam plugs

- Drill and a 2 to 3-inch hole saw / Forstner bit

- 50-100 ft. of 3-6 inch inside diameter ribbed hose

- 1 to $1 \frac{1}{2}$-inch reducer nozzle

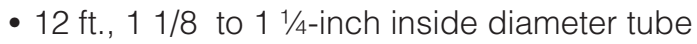

- Best practice: $11 / 8$ to $1 \frac{1}{4}$ - inch tube will match sturdiness of a thin wall irrigation hose

- Note: When connecting hoses, a gradual reduction from the outlet to the $11 / 8-1 \frac{1 / 4}{4}$ inch hose will yield the best results.

\section{One-Hole Tube Fill Method}

The one-hole tube fill method is recommended by state Weatherization Assistance Programs for the retrofit of sidewalls, and is the GreenFiber preferred method for retrofitting existing sidewalls. When performing Weatherization Assistance Program work, follow the instructions below.

\section{Density Check}

GreenFiber requires the use of either a core sampling method or a bag count and volume method to assess the installed density of its products when using the Dry Dense-Pack method. GreenFiber specifications call for a minimum density of 3.5 pcf (pounds per cubic foot) in 2x4 and 2x6 cavities.

These two methods are described below. 


\section{Instructions for One-Hole Tube Fill Method}

1. Remove a section of exterior siding and drill a single 2 $1 / 2$-inch diameter hole through the sheathing approximately one foot from the bottom plate of the wall.
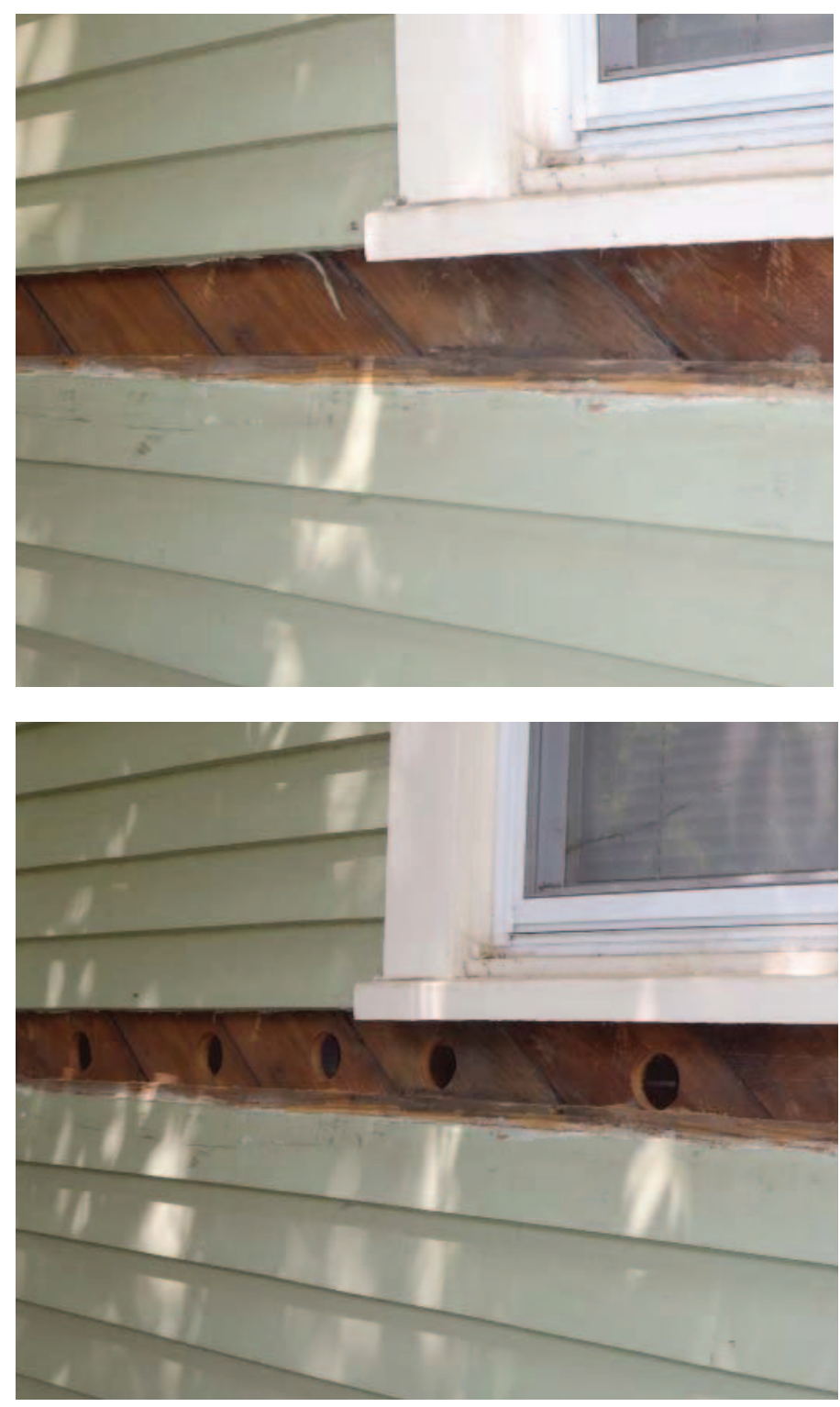

2. Using a hose clamp, attach the 1 to $1 \frac{1}{2}$ - inch reducer nozzle to the insulation blowing machine hose.

3. Using a hose clamp, attach the $12 \mathrm{ft}$., $11 / 8$ or $1 \frac{1 / 4}{-}$ inch inside diameter tube to the end of the reducer nozzle.

4. Using the utility knife, cut the end of tube on a diagonal to facilitate snaking behind wiring and plumbing.

5. Suggested beginning settings for Insulation blowing machine:

a. Material gate set to $25 \%$ of total opening.

b. Air setting at $60 \%$ of capacity.

NOTE: These settings are given as a starting point. Adjustment will be needed based on machine type and condition.

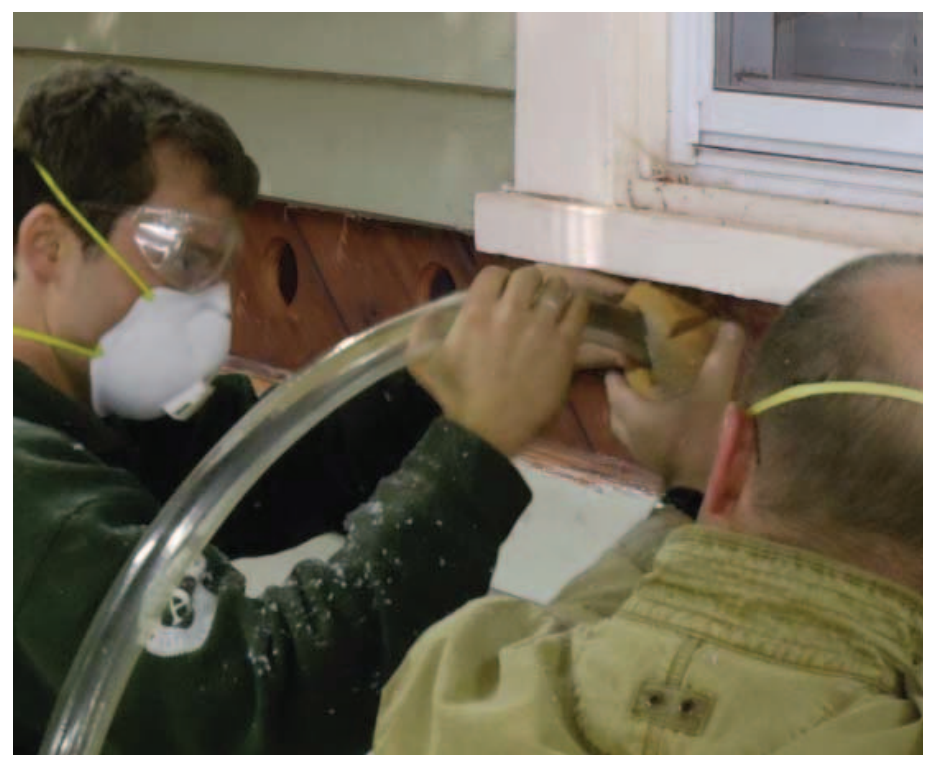

6. Insert cut end of the tube through the filter into the 2 $1 / 2$-inch drilled hole and feed to within 6-inches of the top of the stud cavity. Note any fire stops or other obstructions. Drill additional holes as needed if obstructions are present.

7. Turn on insulation blowing machine (Hold tube in place 6 -inches from top). As material begins to flow, the cavity will fill bottom to top.

8. When you feel resistance from the tube, the cavity is full - DO NOT STOP BLOWING. You will now begin the Dry Dense-Pack Procedure. Dry Dense-Packing is required to achieve the minimum requirement of $3.5 \mathrm{pcf}$ in wall cavities.

9. Dry Dense-Packing means you will begin compressing the material in the cavity and excess air will be forced out the entry hole. Move tube up and down 4 inches until material threatens to plug tube. Then retract the tube 8-10 inches.

10. Repeat Dry Dense-Packing procedures until within 6 inches of the entry hole.

11. When within 6 inches of entry hole quickly redirect tube downward to Dry Dense-Pack bottom of cavity.

12. Repeat Dry Dense-Packing procedures in bottom of cavity.

13. Retract tube to entry hole, jab forward 3 to 4 times to finish Dry Dense-Packing entry area.

14. Turn insulation blowing machine off. Keep tube in hole for 3 to 4 seconds before fully removing from cavity. 


\section{Two-Hole or Double-Blow Method}

The two-hole or double-blow method is the most frequently used procedure for installing loose-fill insulation in sidewalls of existing homes. This method allows air pressure to escape from the upper hole while filling the cavity from the lower hole.

\section{Instructions for Two-Hole or Double-Blow}

1. Remove exterior siding to drill holes wherever possible to avoid potential damage/appearance defects to the exterior of the house.

2. Drill a hole between two studs approximately 2.5 to 3 feet up from the bottom plate. Drill a second hole approximately one foot below the top plate in the same stud run. On a multi-story home, repeat this process on each floor.

3. Drill holes approximately 2-inches in diameter through sheathing if siding is removed. A 2-inch diameter hole enables directional application.

4. Using a hose clamp, attach a 1-inch reducer nozzle to the insulation blowing machine hose.

5. Adjust air pressure to accommodate wall installation and nozzle size. This will ensure proper compacting of insulation and prevent settling in the cavity.

a. Air pressure adjustment will vary depending on machine type and condition. More air pressure is required for sidewall installation than attic installation. Contact the machine manufacturer for the correct settings.

6. Insert the nozzle into the bottom hole first and turn on the blowing machine. An increase in back pressure causes the blower to strain and alerts the installer that the cavity is filled and ready for compaction.
7. When material is no longer flowing through the hose, visually ensure the cavity is completely filled. Move the nozzle to the next hole in the stud cavity. Continue this process until each stud run in the wall is filled.

8. Fill the holes using wood, plastic, cork or Styrofoam plugs. Replace the siding if removed. If siding was not removed, use exterior-grade spackle to cover the plugs.

\section{Contact your GreenFiber technical representative if you have questions regarding coverage, equipment or application at 800.228.0024.}

US GreenFiber (USGF) does not provide architectural, inspection, engineering or building science services and disclaims any responsibility with respect thereto. USGF does not guarantee, warrant or attempt to determine whether a building structure, design or the use of material therein complies with any applicable Codes, standards, guidelines or standards of workmanship. Adding insulation to any part of a home's

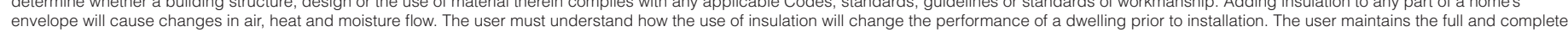

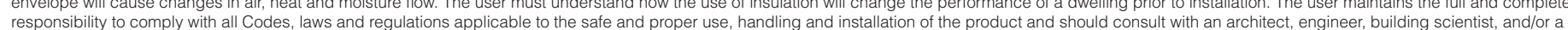

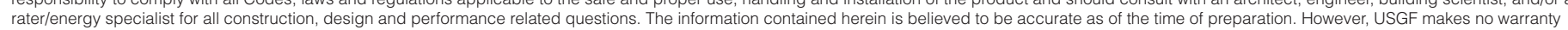
concerning the accuracy of this information. USGF will not be liable for claims relating to the use of information contained herein, regardless of whether it is claimed that the information 
